\title{
HYDROGEOLOGIC FRAMEWORK OF THE DIABASE AQUIFER AT THE BOARHEAD FARMS SUPERFUND SITE, BRIDGETON TOWNSHIP, BUCKS COUNTY, PENNSYLVANIA
}

U.S. GEOLOGICAL SURVEY

Water-Resources Investigations Report 96-4090

Prepared in cooperation with the U.S. ENVIRONMENTAL PROTECTION AGENCY

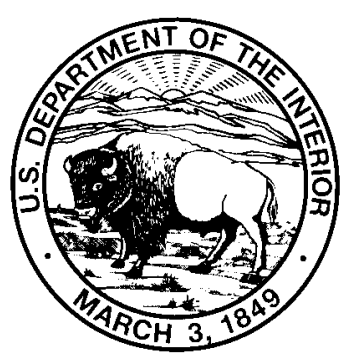




\section{HYDROGEOLOGIC FRAMEWORK OF THE DIABASE AQUIFER AT THE BOARHEAD FARMS SUPERFUND SITE, BRIDGETON TOWNSHIP, BUCKS COUNTY, PENNSYLVANIA}

by Curtis L. Schreffler

U.S. GEOLOGICAL SURVEY

Water-Resources Investigations Report 96-4090

Prepared in cooperation with the U.S. ENVIRONMENTAL PROTECTION AGENCY

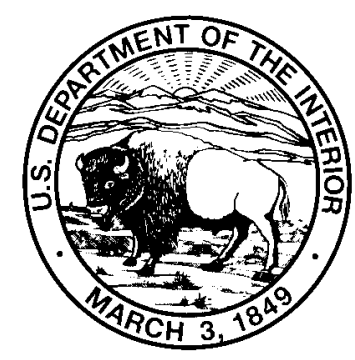

Lemoyne, Pennsylvania 1996 


\title{
U.S. DEPARTMENT OF THE INTERIOR \\ BRUCE BABBITT, Secretary
}

\author{
U.S. GEOLOGICAL SURVEY \\ Gordon P. Eaton, Director
}

For additional information write to:

District Chief

U.S. Geological Survey

840 Market Street

Lemoyne, Pennsylvania 17043-1586
Copies of this report may be purchased from:

U.S. Geological Survey

Earth Science Information Center

Open-File Reports Section

Box 25286, MS 517

Denver Federal Center

Denver, Colorado 80225 


\section{CONIENTS}

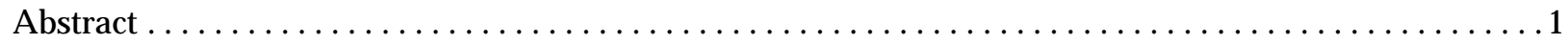

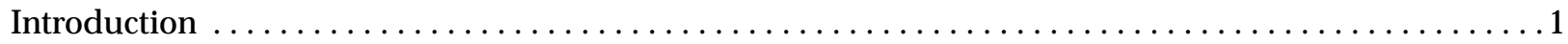

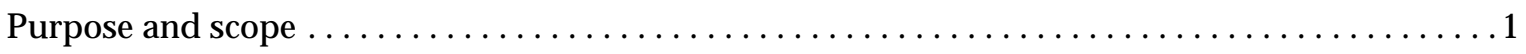

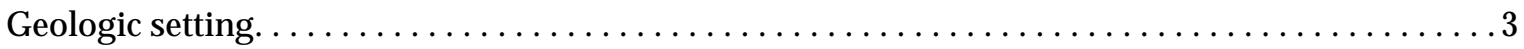

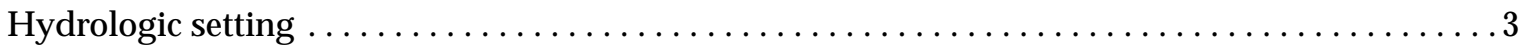

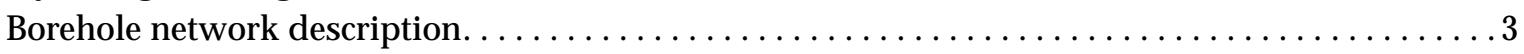

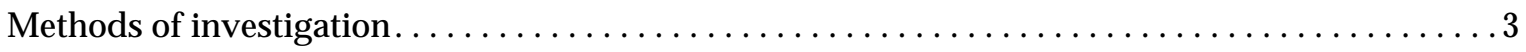

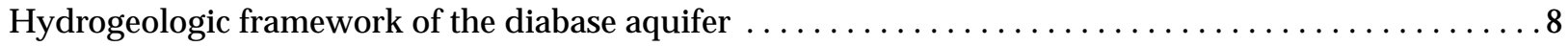

Fractures. . . . . .

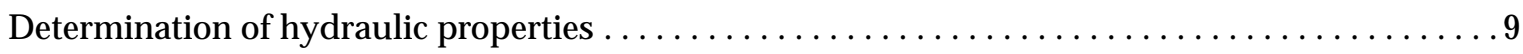

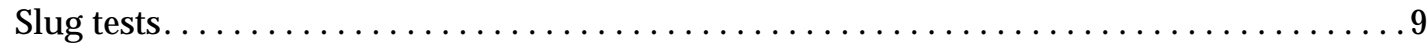

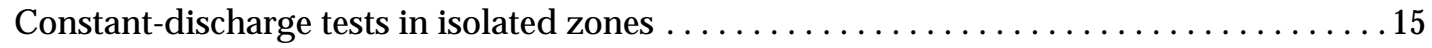

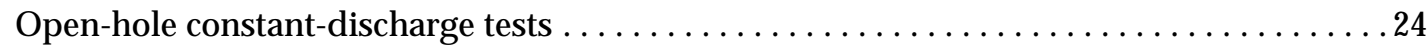

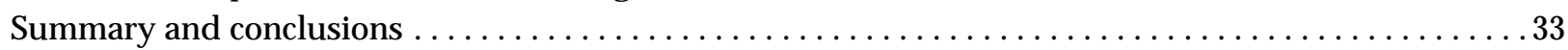

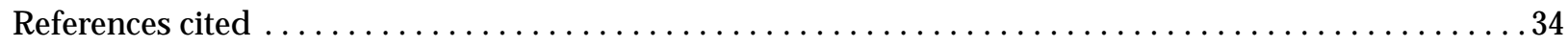

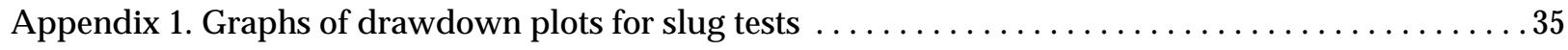

Appendix 2. Graphs of drawdown plots for isolated-zone constant-discharge tests $\ldots \ldots \ldots \ldots \ldots \ldots 4$

Appendix 3. Graphs of drawdown plots for open-hole constant-discharge tests . . . . . . . . . . . 53

\section{IUUSTRATIONS}

Figure 1.-Map showing location of the Boarhead Farms Superfund Site, Bridgeton

Township, Bucks County, Pa.

2.-Map showing borehole locations at the Boarhead Farms site, Bridgeton Township, Bucks County, Pa................................. 4

3.-Generalized sketch of single- and straddle-packer assemblies and pump in a

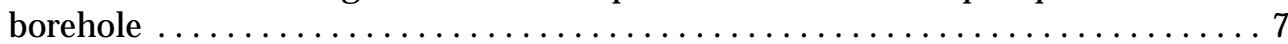

4.-Map showing location of boreholes geophysically logged to determine the thickness of the Coffman Hill diabase sheet, Bridgeton and Nockamixon Townships, Bucks County, Pa.................................... 10

5.-Natural-gamma geophysical logs of boreholes BK-2202, BK-1498, BK-1443, BK-1554, BK-1438, and BK-2347 showing diabase (shale-siltstone) contact, Bridgeton and Nockamixon Townships, Bucks County, Pa .................. 11

6.-Geophysical logs and borehole television survey from borehole BK-2642, Boarhead Farms site, Bridgeton Township, Bucks County, Pa. ................ 12

7.-Graph showing drawdown versus logarithm of time and corresponding type curve for slug test of borehole BK-2638, Boarhead Farms site, Bridgeton Township, Bucks County, Pa. ............................ 13

8.-Graph showing drawdown versus time in the upper zone of borehole BK-2631 for the isolated-zone constant-discharge test, October 6, 1994, Boarhead Farms site, Bridgeton Township, Bucks County, Pa. .................. 15

9.-Graph showing drawdown versus time in the lower zone of borehole BK-2632 for isolated-zone constant-discharge test, September 28, 1994, Boarhead Farms site, Bridgeton Township, Bucks County, Pa. .................... 18 


\section{IWUSTRATIONS-Continued}

Figure 10.-Map showing boreholes used for open-hole constant-discharge tests, Boarhead Farms site, Bridgeton Township, Bucks County, Pa. . . . . . . . . . . . . 25

11.-Graph showing logarithm of drawdown versus logarithm of time and corresponding type curve with match point for open-hole constant-discharge test of borehole BK-2632 on October 27, 1994, Boarhead Farms site, Bridgeton Township, Bucks County, Pa. .............................. 26

\section{Appendix 1}

Figures 1-8.-Graphs showing:

1.-Drawdown versus logarithm of time and corresponding type curve for slug test of borehole BK-2631, Boarhead Farms site, Bridgeton Township, Bucks County, Pa. . . . . . . . . . . . . . . . . . . . . . . . . 36

2.-Drawdown versus logarithm of time and corresponding type curve for slug test of borehole BK-2632, Boarhead Farms site, Bridgeton Township, Bucks County, Pa....................................... 37

3.-Drawdown versus logarithm of time and corresponding type curve for slug test of borehole BK-2636, Boarhead Farms site, Bridgeton Township,

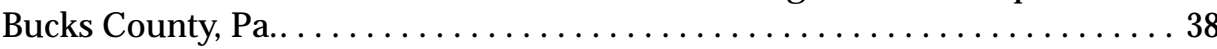

4.-Drawdown versus logarithm of time and corresponding type curve for slug test of borehole BK-2639, Boarhead Farms site, Bridgeton Township, Bucks County, Pa..................................... 39

5.-Drawdown versus logarithm of time and corresponding type curve for slug test of borehole BK-2640, Boarhead Farms site, Bridgeton Township, Bucks County, Pa.................................... 40

6.-Drawdown versus logarithm of time and corresponding type curve for slug test of borehole BK-2641, Boarhead Farms site, Bridgeton Township, Bucks County, Pa................................. 41

7.-Drawdown versus logarithm of time and corresponding type curve for slug test of borehole BK-2642, Boarhead Farms site, Bridgeton Township, Bucks County, Pa................................... 42

8.-Drawdown versus logarithm of time and corresponding type curve for slug test of borehole BK-2643, Boarhead Farms site, Bridgeton Township, Bucks County, Pa................................. 43

\section{Appendix 2}

Figures 1-7.-Graphs showing:

1.-Drawdown versus time in the upper zone of borehole BK-2632 for the isolated-zone constant-discharge test, September 27, 1994, Boarhead Farms site, Bridgeton Township, Bucks County, Pa. . . . . . . . . . . . . 46

2.-Drawdown versus time in the upper zone of borehole BK-2636 for the isolated-zone constant-discharge test, September 22, 1994, Boarhead Farms site, Bridgeton Township, Bucks County, Pa. . . . . . . . . . . . . 47

3.-Drawdown versus time in the upper zone of borehole BK-2639 for the isolated-zone constant-discharge test, September 29, 1994, Boarhead Farms site, Bridgeton Township, Bucks County, Pa. ................ 48 


\section{IWUSTRATIONS-Continued}

Appendix 2-Continued

Figure 4.-Drawdown versus time in the upper and lower zones of borehole BK-2640 for the isolated-zone constant-discharge test, September 27, 1994, Boarhead Farms site, Bridgeton Township, Bucks County, Pa.. . . . . . . . . . . 49

5.-Drawdown versus time in the upper zone of blrehole BK-2641 for the isolated-zone constant-discharge test, September 28, 1994, Boarhead

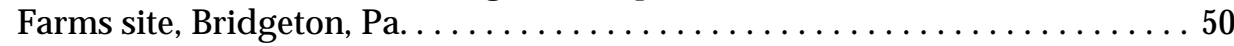

6.-Drawdown versus time in the upper zone of borehole BK-2642 for the isolated-zone constant-discharge test, October 4, 1994, Boarhead Farms site, Bridgeton Township, Bucks County, Pa. . . . . . . . . . . . . . 51

7.-Drawdown versus time in the lower zone of borehole BK-2643 for the isolated-zone constant-discharge test, October 5, 1994, Boarhead

Appendix 3 Farms site, Bridgeton Township, Bucks County, Pa. ............... 52

Figures 1-5.-Graphs showing:

1.-Logarithm of drawdown versus logarithm of time and corresponding type curve with match point for open-hole constant-discharge test of borehole BK-2636 on October 26, 1994, Boarhead Farms site, Bridgeton Township, Bucks County, Pa. ...................... 54

2.-Logarithm of drawdown versus logarithm of time and corresponding type curve with match point for open-hole constant-discharge test of borehole BK-2639 on October 19, 1994, Boarhead Farms site, Bridgeton Township, Bucks County, Pa. ..................... 55

3.-Logarithm of drawdown versus logarithm of time and corresponding type curve with match point for open-hole constant-discharge test of borehole BK-2640 on October 17, 1994, Boarhead Farms site, Bridgeton Township, Bucks County, Pa. ...................... 56

4.--Logarithm of drawdown versus logarithm of time for open-hole constant-discharge test of borehole BK-2641 on October 28, 1994, Boarhead Farms site, Bridgeton Township, Bucks County, Pa. . . . . . . . . 57

5.-Logarithm of drawdown versus logarithm of time and corresponding type curve with match point for open-hole constant-discharge test of borehole BK-2643 on October 20, 1994, Boarhead Farms site, Bridgeton Township, Bucks County, Pa. ..................... 58 
Table 1.-Summary of borehole data for the Boarhead Farms site, Bridgeton Township,

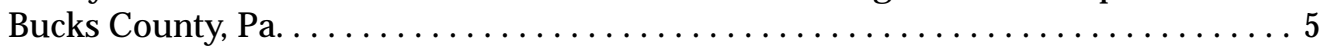

2.-Summary of borehole geophysical logging done by U.S. Geological Survey and fractures at the Boarhead Farms site, Bridgeton Township, Bucks County, Pa. . . . . 14

3.-Transmissivity determined by slug tests, Boarhead Farms site, Bridgeton Township,

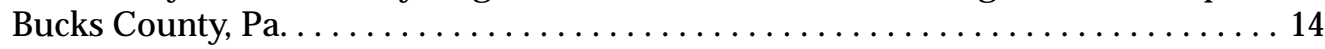

4.-Specific capacity determined by isolated-zone constant-discharge tests, Boarhead Farms site, Bridgeton Township, Bucks County, Pa.................... 16

5.-Drawdown in the lower zone of borehole BK-2631, October 6, 1994, Boarhead Farms site, Bridgeton Township, Bucks County, Pa.................... 17

6.-Drawdown in the upper and lower zones of borehole BK-2636 during upper-isolatedzone test on September 22, 1994, Boarhead Farms site, Bridgeton Township, Bucks County, Pa. ........................................ 19

7.-Drawdown in the upper and lower zones of borehole BK-2636 during lower-isolatedzone test on September 22, 1994, Boarhead Farms site, Bridgeton Township,

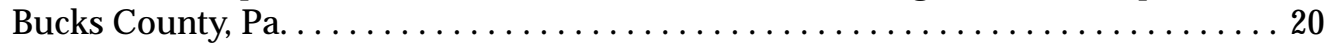

8.-Drawdown in the lower zone of borehole BK-2640, September 27, 1994, Boarhead Farms site, Bridgeton Township, Bucks County, Pa................. 22

9.-Drawdown in the lower zone of borehole BK-2641, September 29, 1994, Boarhead Farms site, Bridgeton Township, Bucks County, Pa.................. 22

10.-Pumping rate, pumping duration, and transmissivity for open-hole constant-discharge tests, Boarhead Farms site, Bridgeton Township, Bucks County, Pa. . . . . . . . . . . 24

11.-Water-level measurements in observation boreholes BK-2631, BK-2633, BK-2643, and BK-2707 during open-hole constant-discharge test of borehole BK-2632, October 27, 1994, Boarhead Farms site, Bridgeton Township, Bucks County, Pa. . . . 27

12.-Water-level measurements in observation boreholes BK-2706, BK-2635, BK-2637, BK-2638 and BK-2708 during open-hole constant-discharge test of borehole BK-2636, October 26, 1994, Boarhead Farms site, Bridgeton Township, Bucks

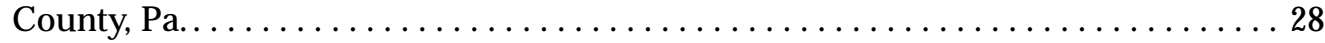

13.-Water-level measurements in observation boreholes BK-2635, BK-2636, BK-2639, and BK-2640 during open-hole constant-discharge test of borehole BK-2638, October 24, 1994, Boarhead Farms site, Bridgeton Township, Bucks County, Pa. . . . 29

14.-Water-level measurements in boreholes BK-2638 and BK-2640 during open-hole constant-discharge test of borehole BK-2639, October 19, 1994, Boarhead Farms site, Bridgeton Township, Bucks County, Pa. . . . . . . . . . . . . . . . 29

15.-Water-level measurements in observation boreholes BK-2639, BK-2641, and BK-2642 during open-hole constant-discharge test of borehole BK-2640, October 18, 1994, Boarhead Farms site, Bridgeton Township, Bucks County, Pa. .............. 30

16.-Water-level measurements in observation boreholes BK-2640 and BK-2642 during open-hole constant-discharge test of borehole BK-2641, October 28, 1994, Boarhead Farms site, Bridgeton Township, Bucks County, Pa. ............. 31

17.-Water-level measurements in observation boreholes BK-2632, BK-2633, BK-2634, BK-2644 and BK-2709 during open-hole constant-discharge test of borehole BK-2643, October 20, 1994, Boarhead Farms site, Bridgeton Township, Bucks County, Pa. . . . . . . . . . . . . . . . . . . . . . . . . . . 32 


\section{CONVERSION FACTORS, VERTICAL DATUM, AND ABBREVIATED WATER-QUALITY UNITS}

Multiply

inch (in.)

foot $(\mathrm{ft})$

mile (mi)

acres

gallon (gal)

gallon per minute (gal/min)

square feet per day $\left(\mathrm{ft}^{2} / \mathrm{d}\right)$

gallon per minute per foot $[(\mathrm{gal} / \mathrm{min}) / \mathrm{ft}]$ by

To obta in

\section{Length}

25.4

0.3048

1.609

Area

4.0469

Volume

3.785

Flow

0.06308

Transmissivity

0.09290

Specific capacity

0.2070 square meter per day

millimeter

meter

kilometer

square kilometer

liter

liter per second

liter per second per meter

Sea level: In this report, "sea level" refers to the National Geodetic Vertical Datum of 1929—a geodetic datum derived from a general adjustment of the first-order level nets of the United States and Canada, called Sea Level of 1929. 



\title{
Hydrogeologic Framework of the Diabase Aquifer at the Boarhead Farms Superfund Site, Bridgeton Township, Bucks County, Pennsylva nia
}

\author{
By Curtis L. Schreffler
}

\begin{abstract}
The hydrogeologic investigation at the Boarhead Farms Superfund Site was done to characterize the framework of the diabase aquifer underlying the site. The primary water-producing fracture system is less than 30 feet below land surface. Water-bearing fractures were not found deeper than 50 feet below land surface. The overburden soil is thin and ranges from 4 to 14 feet thick. The overburden soil acts as a confining unit for the underlying bedrock aquifer. Weathered bedrock consisting of broken diabase ranged from 2 to 15 feet thick, and, in some areas, fractures in the weathered bedrock zone were filled with clay. Due to the clay-rich overburden soil and the thin, clay-filled weathered bedrock zone, little ground-water storage is available to supply the shallow fracture systems.

The diabase aquifer is low yielding with low transmissivities. Five of 15 boreholes drilled as part of the U.S. Geological Survey's investigation produced no water. Estimates of transmissivity calculated from analyses of open-hole constant-discharge tests in five boreholes ranged from 3.1 to 100 square feet per day. Estimated discharge rates for these boreholes adjusted to an 8-hour pumping period ranged from 0.3 to 7.7 gallons per minute. Little to no hydraulic connection exists between boreholes. The fracture system is limited in areal extent. Dewatering of fractures supplying water to boreholes occurred during open-hole constant-discharge tests of three boreholes.
\end{abstract}

\section{INTRODUCTION}

The Boarhead Farms Superfund Site includes about 113 acres in Bridgeton Township, Bucks County, Pa. (fig. 1). During the early and mid-1970's, the Bucks County Department of Health and Pennsylvania Department of Environmental Protection (PaDEP) inspectors reported tank trucks, barrels, and other chemical storage containers at the site. Also in the 1970's, three chemical spills were documented at the site, 3,000 gal of ferrous chloride, 4,000 gal of ammonia, and 2,700 gal of sulfuric acid. In January 1986, a U.S. Environmental Protection Agency (USEPA) site inspection was completed. Soil and water samples collected during the site inspection contained a variety of metals and organic compounds, including chromium, lead, and trichloroethylene (TCE). The Boarhead Farms Site was designated as a Superfund site and placed on the National Priorities List in March of 1989 under the USEPA's Comprehensive Environmental Response, Compensation, and Liability Act program. The USEPA requested the assistance of the U.S. Geological Survey (USGS) in the Boarhead Farms Remedial Design Investigation to support a remedial investigation/feasibility study undertaken by USEPA contractors.

\section{Purpose and Scope}

The purpose of the USGS hydrogeologic investigation was to (1) determine vertical hydraulic connections between the shallow and deep aquifer systems at the site, (2) determine hydraulic properties of the diabase aquifer at the site, and (3) determine locations of water-bearing zones and the hydraulic connection of these zones between boreholes.

This report describes the methods of investigation, summarizes data analyses, and presents the results of the USGS hydrogeologic investigation at the Boarhead Farms site. The report summarizes the borehole-geophysical logs, slug tests, isolated-zone constant-discharge tests, and open-hole constant-discharge tests completed on the site. Depths to fractures that are possible water-bearing zones were determined in 18 boreholes from the borehole-geophysical logs. Aquifer transmissivities were estimated for nine boreholes from the slug tests. Vertical hydraulic connections between shallow and deep aquifer zones were determined and corresponding specific capacities were calculated for each zone in eight boreholes from the isolated-zone constant-discharge tests. Aquifer transmissivities were estimated, and the hydraulic connection of fracture systems between boreholes was determined from seven open-hole constant-discharge tests. 


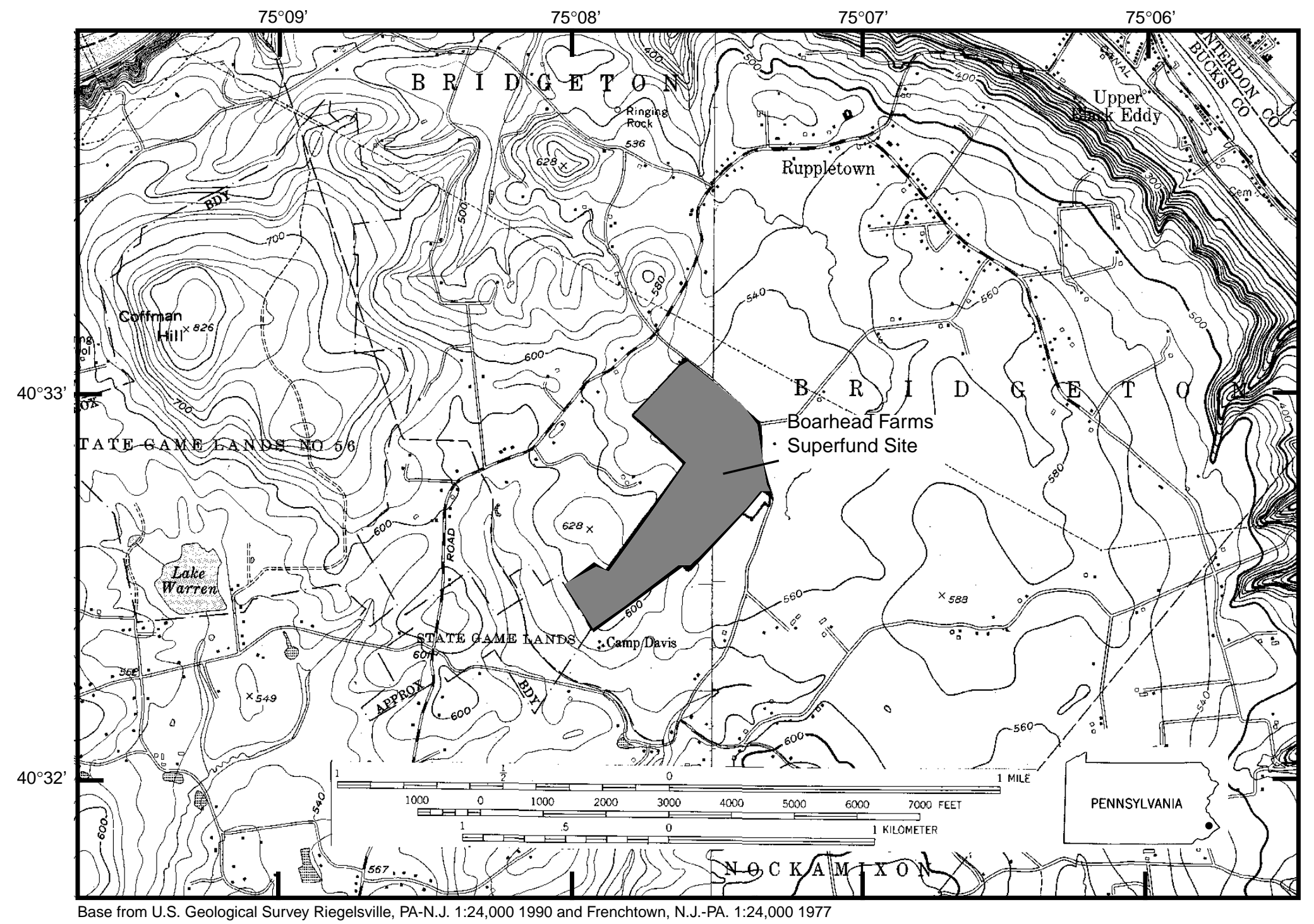

Figure 1. Location of the Boarhead Farms Superfund Site, Bridgeton Township, Bucks County, Pa. 


\section{Geologic Setting}

The Boarhead Farms site is in the Gettysburg-Newark Lowland Section of the Piedmont Physiographic Province. The site is on a topographic high about $3.5 \mathrm{mi}$ west of the Delaware River and about $2 \mathrm{mi}$ southwest of Upper Black Eddy in Bucks County, Pa. (fig. 1).

The site is underlain by early Jurassic-age diabase that was intruded under high temperature and low pressure into sedimentary rocks of the Brunswick Group. Diabase is a dark-gray to black, fine- to coarse-grained, crystalline rock composed largely of calcic plagioclase and augite (Lyttle and Epstein, 1987). The diabase has been exposed by weathering of the softer intruded rocks. Diabase is massive and weathers to large, spheroidal boulders. Diabase boulders weather to a buff-colored, granular sand. The sand, in turn, breaks down into a sticky, red, montmorillonite-type swelling clay.

Diabase sheets in northern Bucks County generally form prominent hills and are discordant sheets with oval or ring-like outcrop patterns (Hotz, 1952; Froelich and Gottfried, 1985). The Boarhead Farms site is underlain by the Coffman Hill diabase sheet. The Coffman Hill sheet is about $3.8 \mathrm{mi}$ wide and $5 \mathrm{mi}$ long and covers a large area in Bridgeton, Tinicum, and Nockamixon Townships in Bucks County and ranges in thickness.

\section{Hydrologic Setting}

Diabase has no primary porosity, and ground water moves through a network of interconnecting fractures. The ground-water flow paths are short, and ground water flows from areas of higher elevation to adjacent streams. Nearly all ground-water storage is in the weathered bedrock zone. Where the weathered bedrock zone is absent, little ground-water storage is available.

Some residential boreholes near the site are drilled through the diabase sheet and penetrate underlying shale and siltstone units of the Brunswick Group. These boreholes generally derive some or all of their water from the underlying shale and siltstone units. In all cases, the underlying shale and siltstone units have a lower hydraulic head, and water from fractures in the diabase penetrated by the borehole will flow downward through the borehole to the underlying units.

\section{Borehole Network Description}

The USEPA Emergency Response contractor for the site drilled 15 boreholes as part of the investigation conducted by the USGS. In addition, prior to this study, the USEPA Remedial Investigations contractor for the site made soil borings to characterize the overburden soil and the weathered bedrock zone. Four of these borings, BK-2706, BK-2707, BK-2708, and BK-2709, which were completed and screened in the overburden soil or weathered bedrock zone, were used as observation boreholes during open-hole constant-discharge tests. The site remedial contractor also drilled five deep on-site boreholes in which geophysical logs were run. The borehole network is shown in figure 2. The USGS identification number, site identification number, depth, driller estimated yield, and screened interval, where applicable, for all boreholes used in this investigation are listed in table 1. Boreholes BK-2633, BK-2634, BK-2635, BK-3637, and BK-2644 had a driller reported yield of less than $1 \mathrm{gal} / \mathrm{min}$ but yielded no water and were not tested. Borehole BK-2700 was only drilled to a depth of $24 \mathrm{ft}$ below land surface datum (LSD) and was not tested. BK-2700 was screened with 4-in. polyvinyl chloride pipe (PVC) from 4 to $24 \mathrm{ft}$ below LSD because of difficulties during drilling.

\section{Methods of Investigation}

Borehole geophysical logging, borehole television surveys, slug tests, isolated-zone constant-discharge tests, and open-hole constant-discharge tests were used in the investigation to characterize the hydrogeologic framework and to determine hydraulic properties of the diabase aquifer. Borehole-geophysical logging and borehole television surveys are effective methods for defining lithostratigraphy, locating potential water-bearing fractures, and locating potential areas of borehole vertical fluid movement. Caliper, natural-gamma, single-point resistance, fluid-resistivity, and fluid-temperature geophysical logs were used at the Boarhead Farms site. 


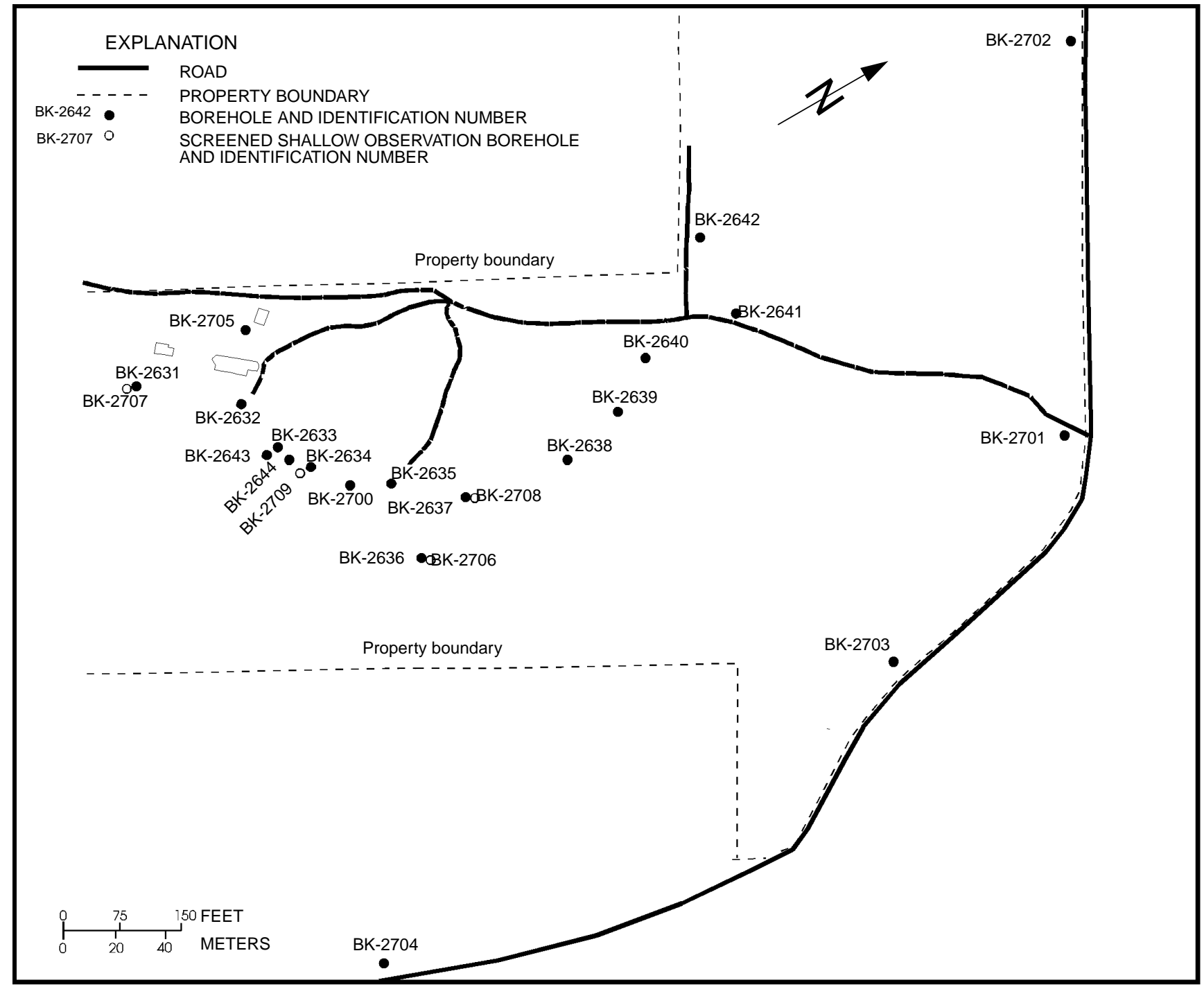

Figure 2. Borehole locations at the Boarhead Farms site, Bridgeton Township, Bucks County, Pa. 
Table 1. Summary of borehole data for the Boarhead Farms site, Bridgeton Township, Bucks County, Pa.

[ft, feet; USGS, U.S. Geological Survey; LSD, land surface datum; gal/min, gallons per minute; <, less than; --, not applicable]

\begin{tabular}{|c|c|c|c|c|}
\hline $\begin{array}{c}\text { USGS } \\
\text { identification } \\
\text { number }\end{array}$ & $\begin{array}{c}\text { Site } \\
\text { identification } \\
\text { number }\end{array}$ & $\begin{array}{c}\text { Depth } \\
\text { (ft below } \\
\text { LSD) }\end{array}$ & $\begin{array}{l}\text { Driller } \\
\text { estimated } \\
\text { yield } \\
\text { (gal } / \mathrm{min} \text { ) }\end{array}$ & $\begin{array}{l}\text { Screened intervals } \\
\text { (ft below LSD) }\end{array}$ \\
\hline BK-2631 & EW-1 & 147 & 2 & -- \\
\hline BK-2632 & EW-2 & ${ }^{1} 146$ & 1 & -- \\
\hline BK-2633 & EW-3 & 52 & $<1$ & -- \\
\hline BK-2634 & EW-4 & 78 & $<1$ & -- \\
\hline BK-2635 & EW-5 & 52 & $<1$ & -- \\
\hline BK-2636 & EW-6 & 148 & 5 & -- \\
\hline BK-2637 & EW-7 & 51 & $<1$ & -- \\
\hline BK-2638 & EW-8 & 138 & 5 & -- \\
\hline BK-2639 & EW-9 & 149 & 2 & -- \\
\hline BK-2640 & EW-10 & 51 & 3 & -- \\
\hline BK-2641 & EW-11 & 60 & 1 & -- \\
\hline BK-2642 & EW-12 & ${ }^{2} 122$ & 7 & -- \\
\hline BK-2643 & EW-13 & 50 & 3 & -- \\
\hline BK-2644 & EW-14 & 48 & $<1$ & -- \\
\hline BK-2700 & ${ }^{3}$ EW-15 & 24 & 5 & $4-24$ \\
\hline BK-2706 & ${ }^{3} \mathrm{MW}-4$ & 11 & -- & $3.5-8.5$ \\
\hline BK-2707 & ${ }^{3} \mathrm{MW}-12$ & 15 & -- & $4-14$ \\
\hline BK-2708 & ${ }^{3} \mathrm{MW}-20$ & 15 & -- & $4.5-14.5$ \\
\hline BK-2709 & ${ }^{3} \mathrm{MW}-21$ & 15 & -- & $5-15$ \\
\hline BK-2701 & MW-24 & 80 & -- & ${ }^{4} 60-80$ \\
\hline BK-2702 & MW-25 & 200 & dry & ${ }^{4} 60-200$ \\
\hline BK-2703 & MW-26 & 150 & -- & ${ }^{4} 125-150$ \\
\hline BK-2704 & MW-27 & 150 & -- & ${ }^{4} 125-150$ \\
\hline BK-2705 & MW-28 & 150 & dry & ${ }^{4} 40-150$ \\
\hline
\end{tabular}

\footnotetext{
${ }^{1}$ Grouted to $8 \mathrm{ft}$ below LSD

${ }^{2}$ Grouted to $28 \mathrm{ft}$ below LSD

${ }^{3}$ Screened in overburden/weathered bedrock

${ }^{4}$ Boreholes screened after investigation
}

Caliper logs provide a continuous record of average borehole diameter, which is related to fractures, lithology, and drilling technique. The tool is calibrated at land surface after each caliper log is run. Caliper logs are used to help correlate lithostratigraphy, to identify fractures that are possible water-bearing zones, and to qualitatively correct other geophysical logs for changes in borehole diameter. Correlation of caliper logs with single-point resistance, fluid-resistivity, and fluid-temperature logs is useful in identifying fractures that are either water-producing or water-receiving zones.

Natural-gamma logs, also called gamma-ray logs, record the natural-gamma radiation emitted from rocks penetrated by the borehole. Uranium-238, thorium-232, and the progeny of their decay series and potassium-40 are the most common emitters of natural-gamma radiation. These radioactive elements may be concentrated in clay by adsorption and ion exchange, and fine-grained sediments, such as the underlying shales and siltstones, typically emit more gamma radiation than diabase. Gamma radiation 
can be measured through casing, but the gamma response is dampened. The natural-gamma logs are used to correlate lithostratigraphy. The natural-gamma log was used principally to indicate if a borehole penetrated the diabase sheet into the underlying shale.

Single-point-resistance logs record the electrical resistance between the borehole and an electrical ground at land surface. In general, resistance increases with grain size and decreases with borehole diameter, density of water-bearing fractures, and increasing concentration of dissolved solids in the borehole fluid. A fluid-filled borehole is required for single-point-resistance logs, and logs are run only for the saturated part of the formation below the casing. Single-point-resistance logs are used to correlate lithostratigraphy and to help identify the location of water-bearing zones.

Fluid-resistivity logs measure the electrical resistivity of fluid in the borehole. Fluid-resistivity logs reflect changes in the concentration of dissolved solids of the borehole fluid. Fluid-resistivity logs are used to identify water-producing and water-receiving zones and to aid in determining intervals of vertical borehole flow. Water-producing and water-receiving zones commonly are identified by sharp changes in fluid resistivity. A low resistivity gradient may indicate an interval of borehole flow between water-producing and water-receiving zones.

Fluid-temperature logs provide a continuous record of the temperature of the fluid in the borehole. Temperature logs are used to identify water-producing and water-receiving zones and to determine intervals of vertical borehole flow. Intervals of vertical borehole flow are identified by little or no temperature gradient.

Borehole television surveys are done by lowering a waterproof video camera with a wide angle lens down the borehole and recording the results on videotape. Television surveys are useful for locating fractures including vertical fractures that may not be detected by the caliper log. Television surveys can be used to find relatively competent areas of the borehole, which are good places to set packers.

Slug tests were used to determine hydraulic properties of the aquifer near the well bore. The duration of slug tests are very short and the estimated transmissivity determined from the tests will be representative only of water-bearing material close to the borehole (Ferris and others, 1962). The slug apparatus was $3.5 \mathrm{ft}$ long, 4-in. PVC pipe, filled with grout and capped on both ends. The slug apparatus was quickly submerged in the borehole to displace a finite volume of water. The subsequent water-level response was measured with a downhole pressure transducer. Measurements from the transducer were recorded with a data logger at the surface.

Data from all slug tests were analyzed with the analytical solution developed by Cooper, Bredehoeft, and Papadopulos (1967). The solution assumes a homogeneous, isotropic, areally extensive, confined aquifer. The method involves normalizing the drawdown data to the highest peak or height of the displaced water column and plotting the normalized drawdown as a function of the logarithm of time. Standard-curve matching techniques were used to match the test data to a theoretical type curve developed by Cooper, Bredehoeft, and Papadopulos (1967). For all slug-test analyses, the theoretical drawdown curve was matched with the observed drawdown curve for late-time data. Because drill cuttings can fill fractures near the well bore and decrease permeability, which can effect the early-time data, the early-time data were not used in the curve match analyses. A software package was used to adjust the type curve and calculate transmissivity for each test (Duffield and Rumbaugh, 1991).

Isolated-zone constant-discharge tests were used to separate shallow and deep aquifer systems and determine the hydraulic connection between the two systems. For boreholes BK-2632 and BK-2636, a straddle-packer system was used to isolate fractures just below the bottom of the casing (fig. 3B). For boreholes BK-2631, BK-2639, BK-2640, BK-2641, BK-2642, and BK-2643, a single-packer system was used to separate the upper and lower parts of the borehole (fig. 3A).

For the isolated-zone constant-discharge tests of boreholes using the straddle-packer system both packers were inflated (fig. 3B). The distance from the center of the upper packer to the center of the lower packer was $18.6 \mathrm{ft}$. The upper packer was inflated just above the bottom of the steel casing. After inflation of the packers, water levels were measured with electric tapes in the isolated upper zone and the lower zone below the lower packer. After the water levels in the two zones stabilized, a pressure transducer was suspended in the isolated upper zone. The pressure transducer was calibrated by measuring pressure at two different known depths. Measurements from the transducer were recorded by a data logger. A submersible pump was lowered into the isolated upper zone, and the borehole was pumped for about 60 minutes. 


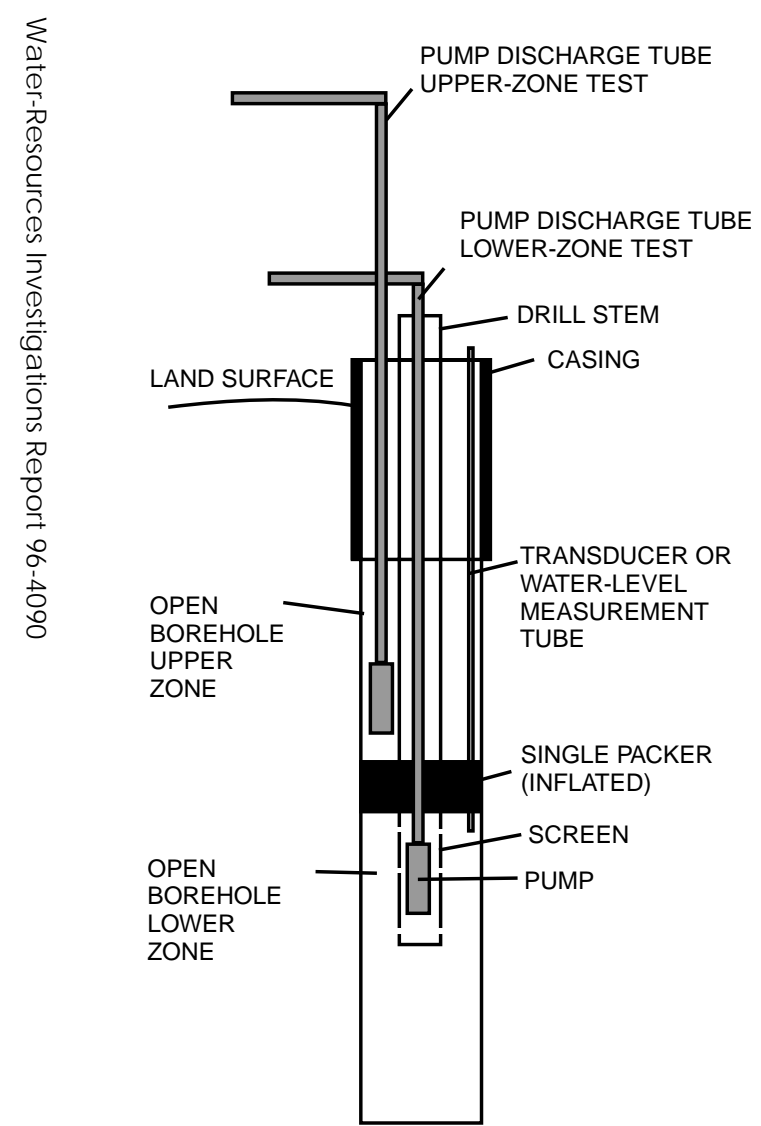

A. SINGLE PACKER INFLATED

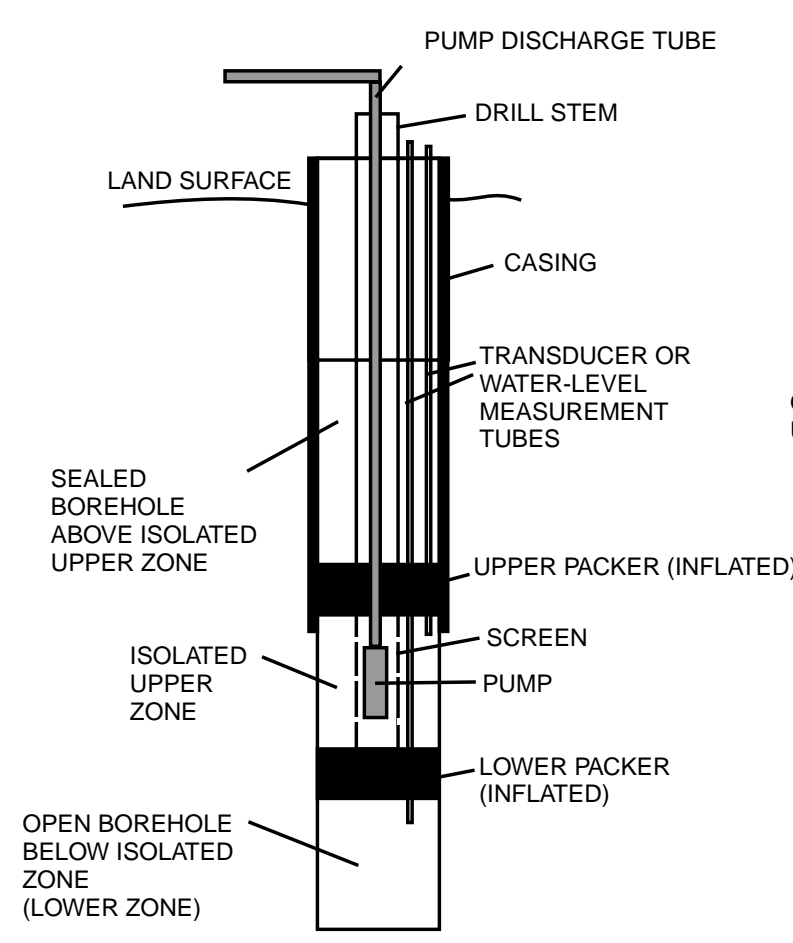

B. BOTH PACKERS INFLATED

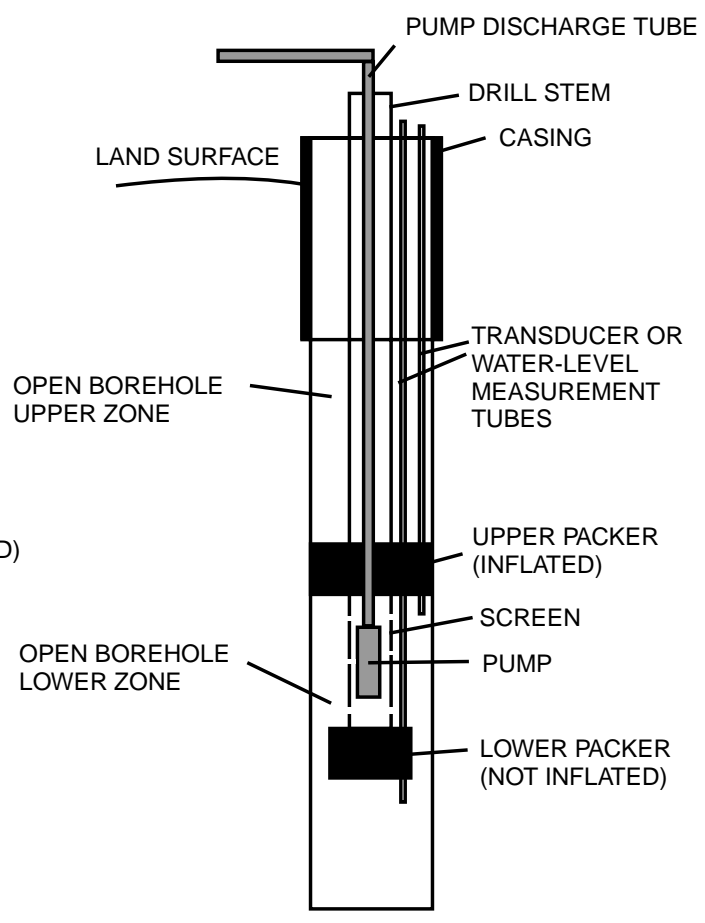

C. UPPER PACKER INFLATED

NOT TO SCALE

Figure 3. Generalized sketch of single- and straddle-packer assemblies and pump in a borehole. 
After the isolated upper zone test was completed, the packer string was lowered in the borehole and only the upper packer was inflated (fig. 3C). Pressure transducers were suspended in the lower and upper zones after water levels in the two zones stabilized. Both transducers were re-calibrated. A submersible pump was lowered into the lower zone, and the zone was pumped for about 60 minutes or until the zone was dewatered.

For the isolated-zone constant-discharge tests of boreholes using a single-packer system, a single packer was used to separate the upper and lower parts of the boreholes (fig. 3A). After inflation of the packer, water levels were measured with electric tapes above and below the packer. Pressure transducers were suspended in the upper and lower zones after the water levels in the two zones stabilized. Both transducers were calibrated by measuring pressure at two different depths in their respective zones. Measurements from the transducers were recorded by a data logger A submersible pump was lowered into the upper zone until it rested on the packer, and the zone was pumped for about 60 minutes. The water-level changes were recorded by the data logger. For the constant-discharge test of the lower zone, the packer and transducers were left in place (fig. 3A). A submersible pump lowered into the lower zone, and the zone was pumped for about 60 minutes or until the zone was dewatered. The water-level changes were recorded by the data logger. For both the upper and lower isolated-zone constant-discharge tests, specific capacities were determined at the end of the pumping period. Specific capacity is determined by dividing drawdown, in feet, by the pumping rate, in gallons per minute.

Open-hole constant-discharge tests were used to determine aquifer transmissivity and the hydraulic connections between adjacent boreholes. For all tests, a pressure transducer was installed in the pumped borehole. The transducer was calibrated by measuring pressure at two different known depths. Measurements from the transducer were recorded by a data logger at the surface. Water-level changes in nearby observation boreholes were measured with pressure transducers or electric tapes. Electric-tape measurements also were taken in boreholes equipped with pressure transducers at irregular time intervals to verify transducer performance.

For the open-hole constant-discharge tests, the only equipment suspended in the borehole was a pump, a discharge line, and a transducer. All discharge water was pumped to holding tanks. All boreholes were open to the atmosphere.

Because the boreholes were 8-in. in diameter and the boreholes were pumped at a low rate, water derived from well-bore storage had to be eliminated to estimate transmissivity. This was done by using the analytical solution developed by Papadopulos and Cooper (1967). The method involves plotting the logarithm of drawdown as a function of the logarithm of time overlain by type curves developed by Papadopulos and Cooper (1967) and presented in Reed (1980). Standard curve-matching techniques were used to match the test data to a theoretical type curve. A match point was chosen, and transmissivity was calculated with the equation presented in Reed (1980, p. 40). This analytical method assumes an extensive, homogeneous, isotropic, fully confined aquifer. An extensive aquifer can be assumed because of the short test duration and low withdrawal rates that spatially affect only a small part of the aquifer.

Discharge rates adjusted for a common 8-hour pumping period were estimated for boreholes in which open-hole constant-discharge tests were completed. The discharge rates were estimated from data on transmissivity, storage coefficient, maximum available drawdown, well radius, and the 8-hour time period. A storage coefficient of 0.0001 was assumed, and maximum available drawdown was defined as the difference in depth between static water level and the depth of the first water-bearing fracture. The estimated discharge rates were calculated by rearranging the Theis (1935) equation presented in Reed (1980, p. 6) and solving for the pumping rate.

\section{HYDROGEOLOGIC FRAMEWORK OF THE DIABASE AQUIFR}

On the basis of USEPA remedial contractor boring logs from 21 shallow boreholes, the overburden soil was characterized as a clayey-silt loam with some sand. Clay also filled the weathered bedrock zone. The clay in the soil and in the weathered bedrock zone is considered a confining unit. The overburden soil contained no water. The thickness of the overburden soil ranged from 4 to $14 \mathrm{ft}$. Because of the clay-rich soil and the thin weathered bedrock zone, little ground-water storage is available to supply the shallow 
fracture system. The thickness of weathered bedrock ranged from 2 to $15 \mathrm{ft}$ with some clay filling the openings of the broken rock. The first water-bearing zone penetrated during boring was in the weathered zone.

Sloto and Schreffler (1994) estimated the thickness of the Coffman Hill sheet with natural-gamma geophysical logs in four boreholes at three different areas of the sheet. Diabase contains few gamma-emitting minerals and is characterized by low natural-gamma emissions. The underlying shale and siltstone contain gamma-emitting minerals and are characterized by much higher natural-gamma emissions than the diabase. Borehole BK-2347, near the center of the sheet and the site, was logged, and the diabase was determined to be about $570 \mathrm{ft}$ thick (fig. 4). The thickness of the sheet, estimated from boreholes BK-2202, BK-1498, and BK-1554, was about $80 \mathrm{ft}$ near the eastern margin, $115 \mathrm{ft}$ near the western margin, and $300 \mathrm{ft}$ near the center of the sheet, respectively (fig. 4). As part of the remedial investigation study, two boreholes adjacent to the site, BK-1438 and BK-1443, were logged in March of 1994, and the thickness of the sheet was estimated to be about 370 and $275 \mathrm{ft}$, respectively. The natural-gamma logs for the six boreholes and the depth below land surface of the diabase-shale contact are shown in figure 5. Natural-gamma logs show that no boreholes drilled as part of the USGS investigation or the remedial investigation penetrated the diabase sheet.

\section{Fractures}

The caliper and single-point resistance logs and the borehole television survey were used to determine depths of fractures that are possible water-bearing zones. The fluid-resistivity and fluid-temperature logs were used to identify possible zones of natural vertical borehole fluid movement. A complete suite of geophysical logs for borehole BK-2642 and the possible water-bearing fractures are shown in figure 6 . The possible water-bearing-fracture depths determined from the geophysical logs are summarized in table 2. Most of the possible water-bearing fractures are within $30 \mathrm{ft}$ of the land surface. The logs did not indicate vertical fluid movement between fractures in any of the boreholes.

\section{Determination of Hydraulic Properties}

Slug tests were done in nine boreholes to determine hydraulic properties in close proximity to the well bore. Isolated-zone constant-discharge tests were done in eight boreholes to determine the vertical hydraulic connection between the shallow and deep parts of the borehole. Specific capacities were determined for each isolated zone. Open-hole constant-discharge tests were done in seven boreholes to estimate aquifer transmissivity and to determine hydraulic connections between adjacent boreholes.

\section{Slug Tests}

Slug tests were done in boreholes BK-2631, BK-2632, BK-2636, BK-2638, BK-2639, BK-2640, BK-2641, BK-2642, and BK-2643. Transmissivities estimated from the slug-test analyses are summarized in table 3. Transmissivity estimates ranged from 2.8 to $14 \mathrm{ft}^{2}$ /day with a median of $4.2 \mathrm{ft}^{2} /$ day in boreholes BK-2631, BK-2632, and BK-2643. Transmissivity estimates ranged from 180 to $440 \mathrm{ft}^{2} /$ day with a median of $295 \mathrm{ft}^{2} /$ day in boreholes BK-2636, BK-2638, BK-2640, and BK-2642. A two order of magnitude difference in median transmissivity estimates exists between these groups of boreholes. Either somewhat conductive fractures were penetrated, and boreholes yielded some water or nonconductive fractures or no fractures were penetrated, and boreholes yielded little to no water. Transmissivities could not be estimated for boreholes BK-2639 and BK-2641 because of a poor match between the data and the type curve. A plot of drawdown as a function of elapsed time and the corresponding matched type curve for borehole BK-2638 is shown in figure 7. Appendix 1 contains plots of drawdown as a function of the elapsed time and corresponding matched type curves for each slug test. 


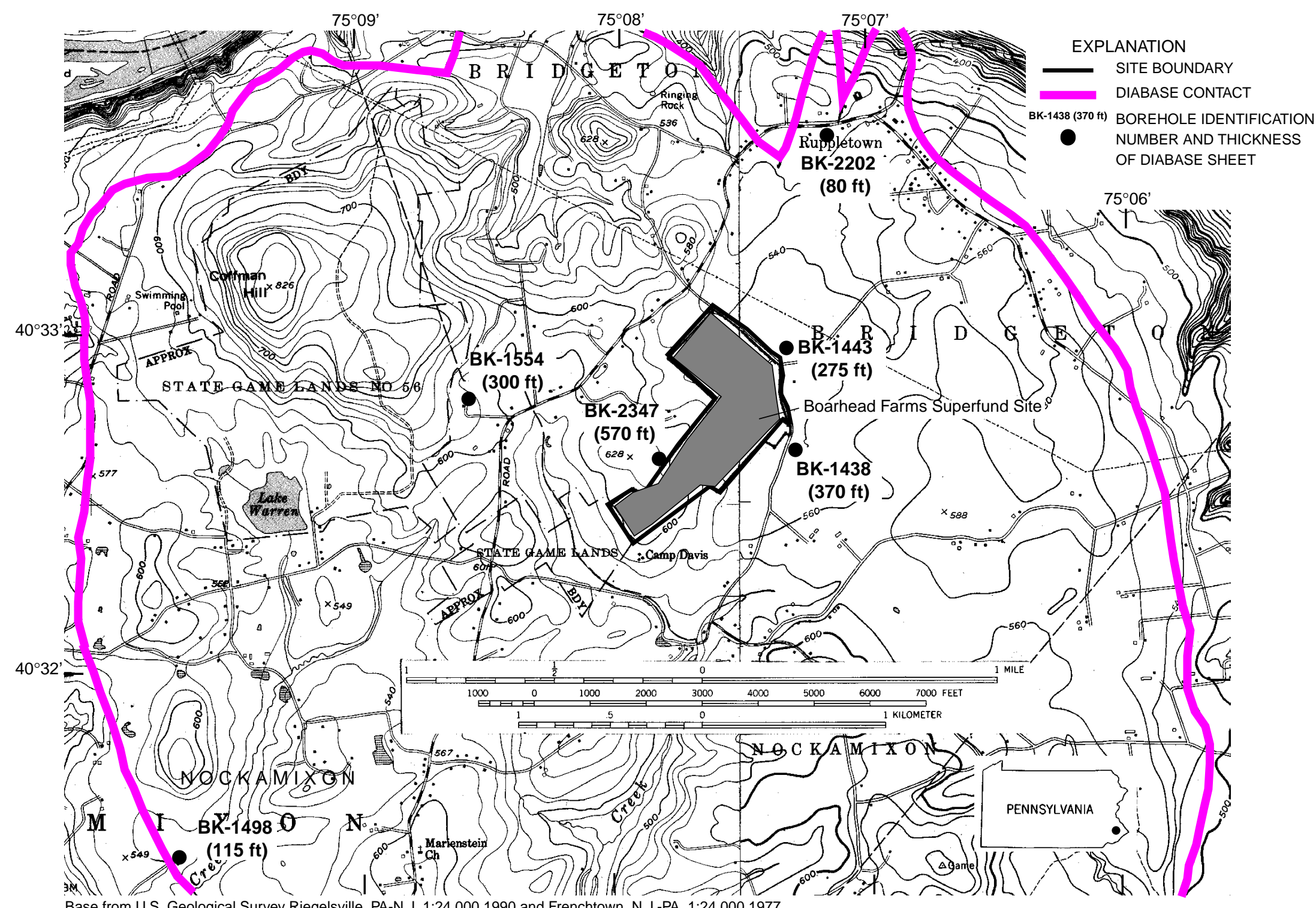

Figure 4. Location of boreholes geophysically logged to determine the thickness of the Coffman Hill diabase sheet, Bridgeton and Nockamixon Townships, Bucks County, Pa. 


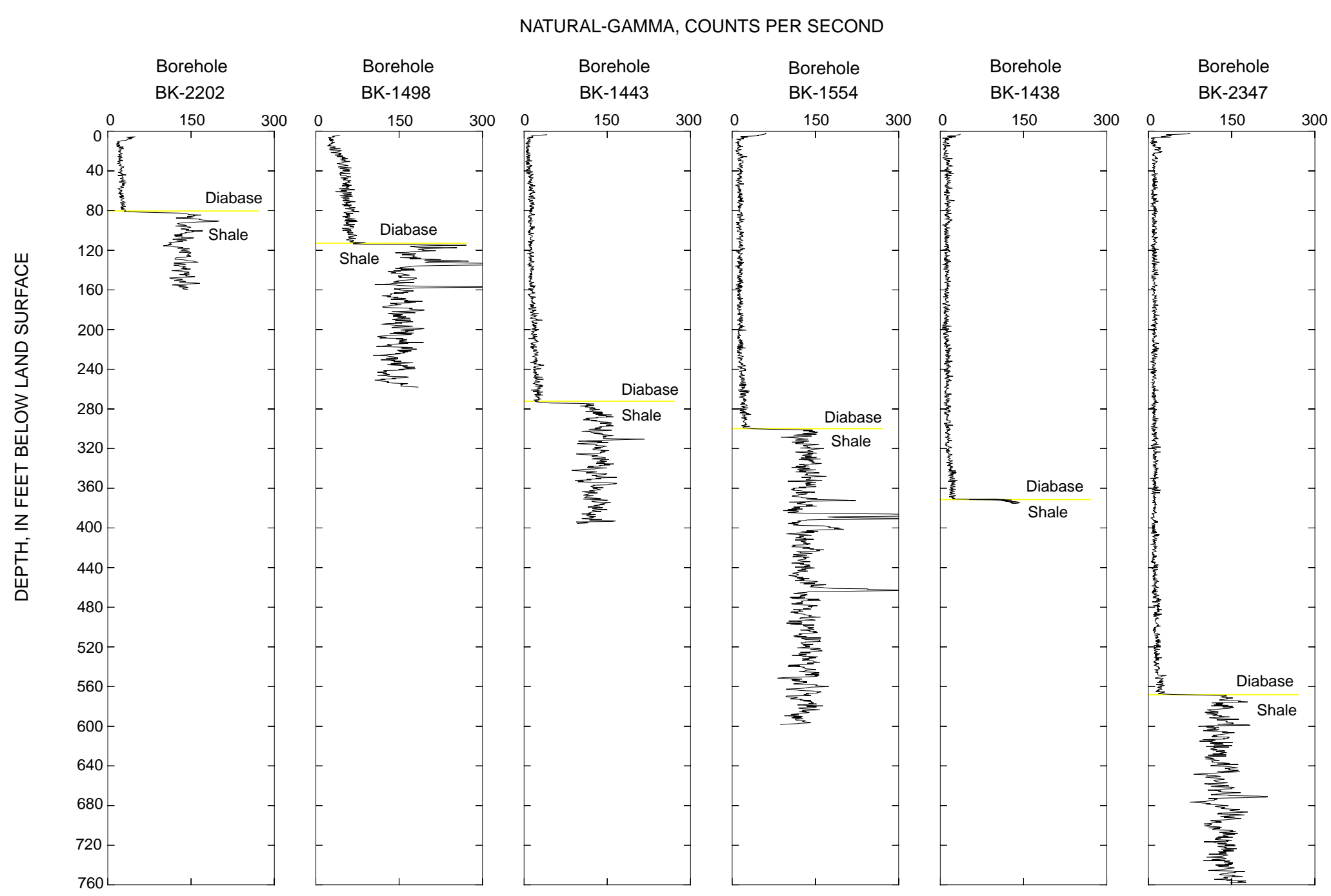

Figure 5. Natural-gamma geophysical logs of boreholes BK-2202, BK-1498, BK-1443, BK-1554, BK-1438, and BK-2347 showing diabase (shale-siltstone) contact, Bridgeton and Nockamixon Townships, Bucks County, Pa. 


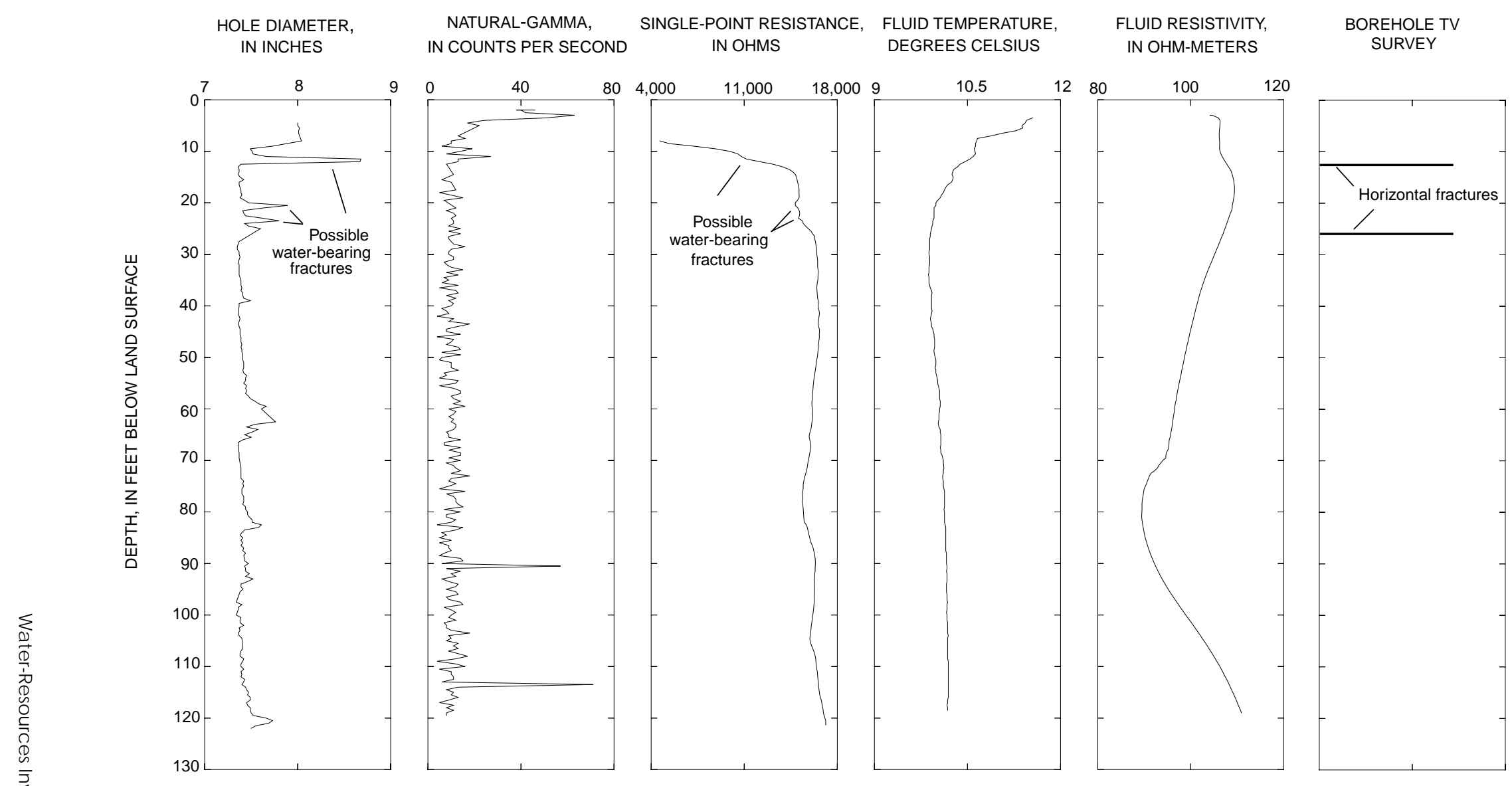

Figure 6. Geophysical logs and borehole television survey from borehole BK-2642, Boarhead Farms site, Bridgeton Township, Bucks County, Pa. 


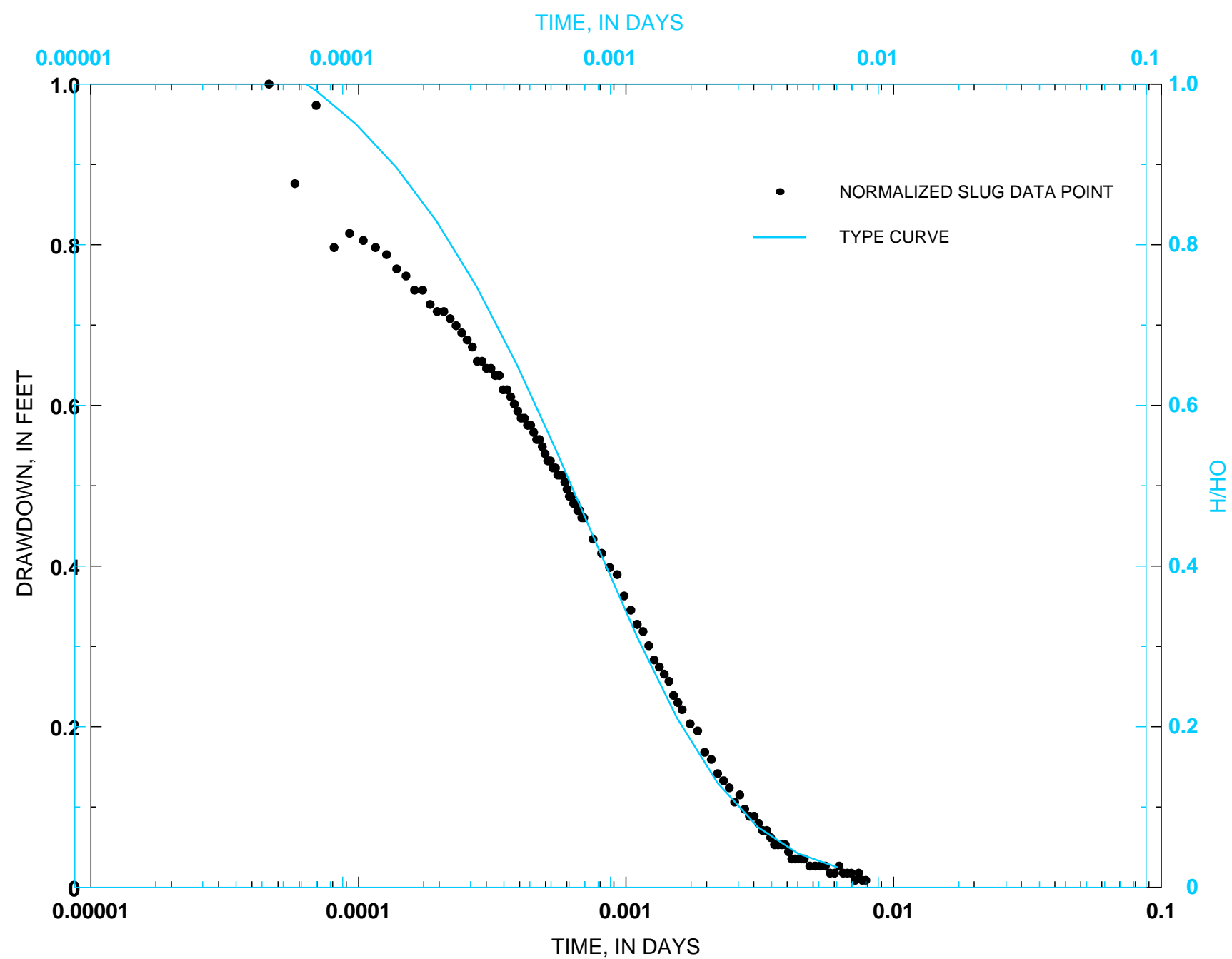

Figure 7. Drawdown versus logarithm of time and corresponding type curve for slug test of borehole BK-2638, Boarhead Farms site, Bridgeton Township, Bucks County, Pa. 
Table 2. Summary of borehole geophysical logging done by U.S. Geological Survey and fractures at the Boarhead Farms site, Bridgeton Township, Bucks County, Pa.

[USGS, U.S. Geological Survey; C, caliper log; G, natural-gamma log; S, single-point-resistance log; F, fluid- resistivity log; T, fluid-temperature log; L, borehole television survey; ft, feet; LSD, land surface datum; --, no apparent water-bearing zones]

\begin{tabular}{|c|c|c|c|c|c|}
\hline $\begin{array}{c}\text { USGS } \\
\text { identification } \\
\text { number }\end{array}$ & $\begin{array}{l}\text { Date borehole } \\
\text { logged }\end{array}$ & $\begin{array}{l}\text { Geophysical logs } \\
\text { and television } \\
\text { surveys run }\end{array}$ & $\begin{array}{c}\text { Maximum depth } \\
\text { logged } \\
\text { (ft below LSD) }\end{array}$ & $\begin{array}{l}\text { Depth of casing } \\
\text { (ft below LSD) }\end{array}$ & $\begin{array}{c}\text { Depth of fractures } \\
\text { (ft below LSD) }\end{array}$ \\
\hline BK-2631 & August 9, 1994 & $\mathrm{C}, \mathrm{G}, \mathrm{S}, \mathrm{F}, \mathrm{T}, \mathrm{L}$ & 147 & 11 & 15,22 \\
\hline BK-2632 & August 9, 1994 & C, G, S, F, T, L & 148 & 16 & $18,19.5,22.5,29$ \\
\hline BK-2634 & October 11, 1994 & $C, G, S, F, T, L$ & 78 & 13 & $17.5,19,23$ \\
\hline BK-2635 & August 8, 1994 & C, G, S, F, T, L & 52 & 13 & -- \\
\hline BK-2636 & August 8, 1994 & $C, G, S, F, T, L$ & 148 & 18 & 18 \\
\hline BK-2637 & August 8, 1994 & $C, G$ & 52 & 19 & -- \\
\hline BK-2638 & August 9, 1994 & $C, G, S, F, T$ & 138 & 14 & 14.5 \\
\hline BK-2639 & August 8, 1994 & $C, G, S, F, T, L$ & 149 & 10 & 12 \\
\hline BK-2640 & October 7, 1994 & $C, G, S, F, T, L$ & 51 & 13 & $25,35,51$ \\
\hline BK-2641 & August 8, 1994 & C, G, S, F, T, L & 60 & 13 & $16.5,18$ \\
\hline BK-2642 & October 12, 1994 & C, G, S, F, T, L & 122 & 9 & $13,21,23,25.5,63$ \\
\hline BK-2643 & October 11, 1994 & C, G, S, F, T, L & 50 & 16 & 28 \\
\hline BK-2644 & October 11, 1994 & $\mathrm{C}, \mathrm{G}, \mathrm{S}, \mathrm{F}, \mathrm{T}, \mathrm{L}$ & 49 & 13 & -- \\
\hline BK-2701 & October 7, 1994 & $\mathrm{C}, \mathrm{G}, \mathrm{S}, \mathrm{F}, \mathrm{T}$ & 188 & 30 & -- \\
\hline BK-2702 & October 11, 1994 & $C, G$ & 199 & 33 & -- \\
\hline BK-2703 & October 11, 1994 & $C, G, S, F, T$ & 149 & 30 & -- \\
\hline BK-2704 & October 11, 1994 & $C, G, S, F, T$ & 147 & 30 & -- \\
\hline BK-2705 & October 12, 1994 & $C, G$ & 148 & 29 & -- \\
\hline
\end{tabular}

Table 3. Transmissivity determined by slug tests, Boarhead Farms site, Bridgeton Township, Bucks County, Pa.

[USGS, U.S. Geological Survey; $\mathrm{ft}^{2} /$ day, square feet per day: --, not determined]

\begin{tabular}{ccc}
\hline $\begin{array}{c}\text { USGS } \\
\text { identification } \\
\text { number }\end{array}$ & Date of test & $\begin{array}{c}\text { Transmissivity } \\
\text { estimates } \\
\left(\mathrm{ft}^{2} / \text { day }\right)\end{array}$ \\
\hline BK-2631 & September 7, 1994 & 4.2 \\
BK-2632 & September 7, 1994 & 2.8 \\
BK-2636 & September 6, 1994 & 320 \\
BK-2638 & September 7, 1994 & 270 \\
BK-2639 & September 7, 1994 & -1 \\
BK-2640 & September 7, 1994 & 180 \\
BK-2641 & September 6, 1994 & --1 \\
BK-2642 & September 6, 1994 & 440 \\
BK-2643 & September 7, 1994 & 14 \\
\hline
\end{tabular}

${ }^{1}$ No acceptable curve matches were obtained. 


\section{Constant-Discharge Tests in Isolated Zones}

Constant-discharge tests in isolated zones were done in boreholes BK-2631, BK-2632, BK-2636, BK-2639, BK-2640, BK-2641, BK-2642, and BK-2643. The tests were done with a single or straddle inflatable packer system. Specific capacities were calculated in isolated zones at the end of the pumping period. Data from the isolated-zone constant-discharge tests are summarized in table 4.

An isolated-zone constant-discharge test was done in the upper zone of borehole BK-2631 on October 6, 1994. A single packer was set at $47.4 \mathrm{ft}$ below LSD and a pump was set above the packer at $43 \mathrm{ft}$ below LSD. The initial pumping rate was $1.5 \mathrm{gal} / \mathrm{min}$. The rate was increased for the first several minutes of the test until the rate was $3.0 \mathrm{gal} / \mathrm{min}$, which was maintained for the duration of pumping. The upper zone was pumped for 72 minutes. A plot of drawdown as a function of time for the upper zone is shown in figure 8 .

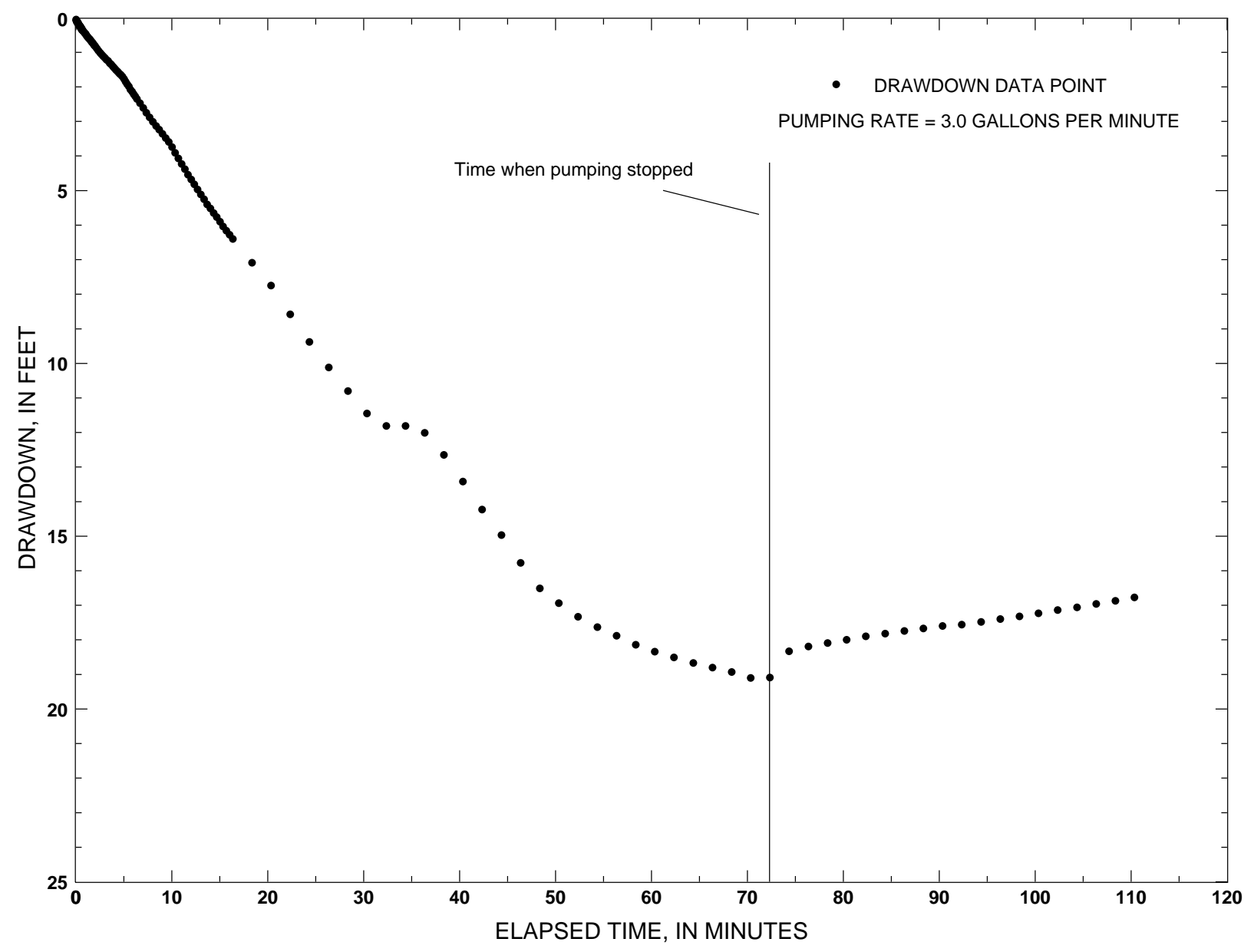

Figure 8. Drawdown versus time in the upper zone of borehole BK-2631 for the isolated-zone constant-discharge test, October 6, 1994, Boarhead Farms site, Bridgeton Township, Bucks County, Pa. 
Table 4. Specific capacity determined by isolated-zone constant-discharge tests, Boarhead Farms site, Bridgeton Township, Bucks County, Pa.

[USGS, U.S. Geological Survey; ft, feet; LSD, land surface datum; gal/min, gallons per minute; min, minutes; gal/min/ft, gallons per minute per foot of drawdown; < less than; --, not determined]

\begin{tabular}{|c|c|c|c|c|c|c|c|c|c|}
\hline \multirow{2}{*}{$\begin{array}{c}\text { USGS } \\
\text { identification } \\
\text { numbers }\end{array}$} & \multirow{2}{*}{ Date of test } & \multirow{2}{*}{$\begin{array}{l}\text { Packer setting } \\
\text { (ft below LSD) }\end{array}$} & \multicolumn{2}{|c|}{ Pumping rate (gal/min) } & \multicolumn{2}{|c|}{ Pumping duration (min) } & \multicolumn{2}{|c|}{ Specific Capacity (gal/min/ft) } & \multirow{2}{*}{ Remarks } \\
\hline & & & Upper zone & Lower zone & Upper zone & Lower zone & Upper zone & Lower zone & \\
\hline BK-2631 & October 6, 1994 & 47.4 & 3.0 & 1.5 & 72 & 16 & 0.16 & -- & Lower zone pumped dry \\
\hline $\begin{array}{l}\text { BK-2632 } \\
\text { (Upper Zone) }\end{array}$ & September 27, 1994 & ${ }^{1} 15.6 / 34.2$ & 1.3 & -- & 47 & -- & .06 & -- & \\
\hline $\begin{array}{l}\text { BK-2632 } \\
\text { (Lower Zone) }\end{array}$ & September 28, 1994 & 57.6 & -- & 1.3 & -- & 14 & -- & -- & Lower zone pumped dry \\
\hline $\begin{array}{l}\text { BK-2636 } \\
\text { (Upper Zone) }\end{array}$ & September 22, 1994 & ${ }^{2} 16.5 / 35.1$ & 4.1 & -- & 60 & -- & .89 & -- & \\
\hline $\begin{array}{l}\text { BK-2636 } \\
\text { (Lower Zone) }\end{array}$ & September 22, 1994 & 58.0 & -- & $<1.0$ & -- & 12 & -- & -- & Lower zone pumped dry \\
\hline BK-2639 & $\begin{array}{l}\text { September 29, and } \\
\text { October } 4,1994\end{array}$ & 47.4 & 3.5 & 2.0 & 50 & 11 & .10 & -- & Lower zone pumped dry \\
\hline BK-2640 & September 27, 1994 & 27.3 & 3.3 & -- & 54 & -- & .60 & -- & \\
\hline BK-2641 & $\begin{array}{l}\text { September } 28 \text { and 29, } \\
1994\end{array}$ & 27.0 & 0.5 & 1.5 & 68 & 19 & .02 & -- & Lower zone pumped dry \\
\hline BK-2642 & October 4 and 5, 1994 & 67.9 & 4.5 & 3.0 & 72 & 5 & 1.1 & -- & Lower zone pumped dry \\
\hline BK-2643 & October 5, 1994 & 26.6 & 1.7 & 2.8 & 35 & 68 & -- & 0.11 & Upper zone pumped dry \\
\hline
\end{tabular}

${ }^{1}$ Upper packer set at 15.6 feet below LSD; lower packer set at 34.2 feet below LSD

${ }^{2}$ Upper packer set at 16.5 feet below LSD; lower packer set at 35.1 feet below LSD 
Maximum drawdown in the upper zone was $19.10 \mathrm{ft}$, and maximum drawdown in the lower zone was $0.49 \mathrm{ft}$. However, the pressurization of the packer caused the $0.49 \mathrm{ft}$ water-level decline in the lower zone. Packer pressurization displaces a finite volume of water and causes the water levels in both zones to rise. Because of the low permeability of the lower zone, the displaced water did not have sufficient time to enter the formation for the water level to stabilize. After 46 minutes of stabilization time and before pumping began, the water level in the lower zone was $3.10 \mathrm{ft}$ higher than the water level in the upper zone. The water level in the lower zone continued to decline throughout the duration of the pumping and recovery periods of the upper-zone test, which also indicates the water level in the lower zone had not stabilized. Therefore, the water level in the lower zone was not at static conditions when pumping began.

No vertical hydraulic connection between the upper and lower zones was apparent. Specific capacity of the upper zone was 0.16 (gal/ $\mathrm{min}) / \mathrm{ft}$ after 72 minutes of pumping.

A constant-discharge test of the lower zone of borehole BK-2631 was also done on October 6, 1994. The packer was left in place at $47.4 \mathrm{ft}$ below LSD. The pump was set at approximately $59 \mathrm{ft}$ below LSD. The water level in the upper zone was $18.5 \mathrm{ft}$ below LSD and was not fully recovered from the packer test of the upper zone. The water level in the lower zone was $4.1 \mathrm{ft}$ above LSD at the start of the test. The pumping rate was $1.5 \mathrm{gal} / \mathrm{min}$. The drawdown was $50.27 \mathrm{ft}$ after 4 minutes of pumping, and the water level was below the pressure transducer. Water-level measurements were continued using electric tapes. The pump was shut off after approximately 16 minutes of pumping because the lower zone was dewatered. Drawdown in the lower zone is listed in table 5.

Table 5. Drawdown in the lower zone of borehole BK-2631, October 6, 1994, Boarhead Farms site, Bridgeton Township, Bucks County, Pa.

[ft, feet; min, minutes]

\begin{tabular}{lcc}
\hline Time & $\begin{array}{c}\text { Elapsed time } \\
\text { since pumping } \\
\text { began (min) }\end{array}$ & Drawdown (ft) \\
\hline 1:53 p.m. & \multicolumn{2}{c}{ Pump turned on } \\
1:54 & 1 & 20.88 \\
1:56 & 3 & 44.93 \\
1:57 & 4 & 50.27 \\
2:09 & 16 & 62.75 \\
2:09 & \multicolumn{2}{c}{ Pump shut off } \\
2:12 & 19 & 61.44 \\
2:13 & 20 & 61.43 \\
$2: 15$ & 22 & 61.42 \\
2:16 & 23 & 61.43 \\
2:18 & 25 & 61.44 \\
2:20 & 27 & 61.42 \\
2:23 & 30 & 61.41 \\
2:26 & 33 & 61.41 \\
2:30 & 37 & 61.41 \\
\hline
\end{tabular}

Maximum drawdown in the lower zone was $62.75 \mathrm{ft}$. Drawdown decreased slightly after the pump was shut off due to water draining down the discharge line. The water level in the lower zone did not recover, indicating no water-producing zones are below $47 \mathrm{ft}$ below LSD. The upper zone continued to 
recover while the lower zone was being pumped, which suggests no vertical hydraulic connection between the lower and upper zones. Specific capacity of the lower zone was not determined because the drawdown could be attributed to only withdrawing water from borehole storage.

An isolated-zone constant-discharge test was done in the upper zone of borehole BK-2632 on September 27, 1994. A straddle packer was set with the center of the upper packer at $15.6 \mathrm{ft}$ below LSD, which was above the bottom of the steel casing. The center of the lower packer was set at $34.2 \mathrm{ft}$ below LSD. A pump was set at $27 \mathrm{ft}$ below LSD. The initial pumping rate was $2.5 \mathrm{gal} / \mathrm{min}$. The rate was lowered to $1.3 \mathrm{gal} / \mathrm{min}$ after 8 minutes of pumping, which was maintained for the duration of the test. The upper zone was pumped for 47 minutes. A plot of drawdown as a function of time for the upper zone is shown in figure 1 of appendix 2.

Maximum drawdown in the upper zone was $20.35 \mathrm{ft}$. No water-level change was measured in the lower zone. No vertical hydraulic connection between the upper and lower zone was apparent. Specific capacity of the upper zone was $0.06(\mathrm{gal} / \mathrm{min}) / \mathrm{ft}$ after 47 minutes of pumping.

On September 28, 1994, the packer string was lowered in borehole BK-2632. The upper packer was inflated with the center of the packer set at $57.6 \mathrm{ft}$ below LSD. A pump was set below the packer at a depth of approximately $69 \mathrm{ft}$ below LSD. The initial pumping rate was $1.3 \mathrm{gal} / \mathrm{min}$. Drawdown was $50.29 \mathrm{ft}$ after 10 minutes of pumping and discharge from the zone stopped. The pump was shut off after 14 minutes of pumping because the lower zone was dewatered. A plot of drawdown as a function of time for the lower zone in borehole BK-2632 is shown in figure 9.

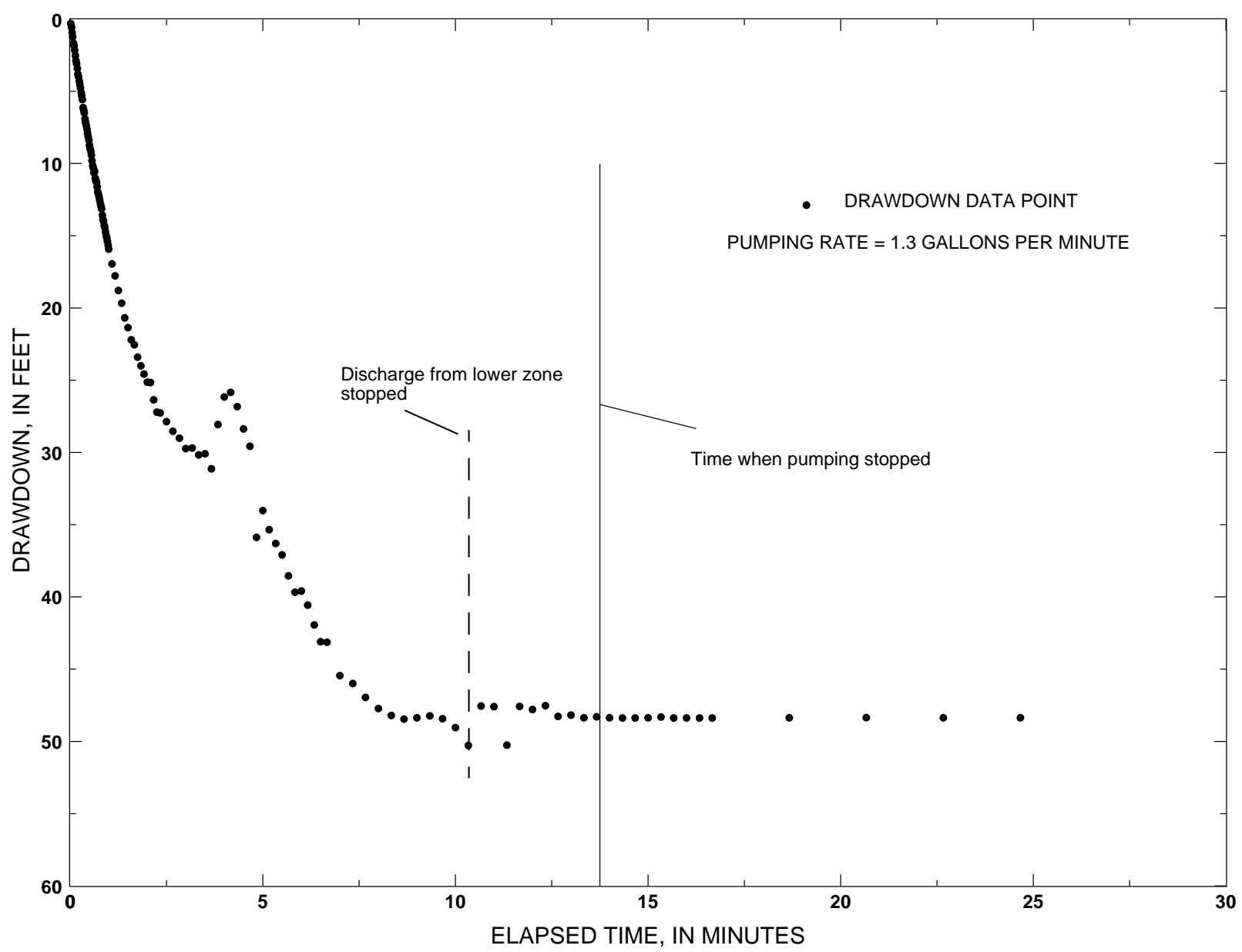

Figure 9. Drawdown versus time in lower zone of borehole BK-2632 for isolated-zone constant-discharge test, September 28, 1994, Boarhead Farms site, Bridgeton Township, Bucks County, Pa. 
Maximum drawdown in the lower zone was $50.29 \mathrm{ft}$. The water level of the lower zone did not recover, indicating no significant water-producing zones are below $58 \mathrm{ft}$ below LSD. Maximum drawdown in the upper zone was $0.13 \mathrm{ft}$, which was probably because of a small leak in the seal of the packer. No vertical hydraulic connection between the lower and upper zones was apparent. Specific capacity of the lower zone was not determined because the drawdown could be attributed to only withdrawing water from borehole storage.

An isolated-zone constant-discharge test was done in the upper zone of borehole BK-2636 on September 22, 1994. A straddle packer was set with the center of the upper packer at $16.5 \mathrm{ft}$ below LSD, which was above the bottom of the steel casing. The center of the lower packer was set at $35.1 \mathrm{ft}$ below LSD. A pump was set at approximately $28 \mathrm{ft}$ below LSD. The pumping rate was $4.1 \mathrm{gal} / \mathrm{min}$. The upper zone was pumped for 60 minutes. Because of pressure transducer malfunctions, water-level measurements in borehole BK-2636 were made with electric tapes. A plot of drawdown as a function of time for the upper zone is shown in figure 2 of appendix 2.

Maximum drawdown in the upper zone was $4.62 \mathrm{ft}$. The lower zone had a static water level of $4.38 \mathrm{ft}$ below the top of the riser pipe just before the start of pumping. At the end of pumping, the water level in the lower zone was $4.92 \mathrm{ft}$ below the top of the riser pipe. Pressurization of the packer caused the $0.54 \mathrm{ft}$ water-level decline in the lower zone during the test. The water level in the upper zone recovered to within $0.32 \mathrm{ft}$ of initial static level 10 minutes after the pump was shut off. The water level in the lower zone continued to decline, which indicates the lower zone was not at static conditions when the test began.

No vertical hydraulic connection between the upper and lower zone was apparent. Drawdown in the upper and lower zones are listed in table 6. Specific capacity of the upper zone was $0.89(\mathrm{gal} / \mathrm{min}) / \mathrm{ft}$ after 60 minutes of pumping.

Table 6. Drawdown in the upper and lower zones of borehole BK-2636 during upper-isolated-zone test on September 22, 1994, Boarhead Farms site, Bridgeton Township, Bucks County, Pa.

[ft, feet; min, minutes; --, measurement not taken]

\begin{tabular}{|c|c|c|c|c|c|c|c|}
\hline \multirow{2}{*}{ Time } & \multirow{2}{*}{$\begin{array}{l}\text { Elapsed time } \\
\text { since pumping } \\
\text { began (min) }\end{array}$} & \multicolumn{2}{|c|}{ Drawdown (ft) } & \multirow{2}{*}{ Time } & \multirow{2}{*}{$\begin{array}{l}\text { Elapsed time } \\
\text { since pumping } \\
\text { began (min) }\end{array}$} & \multicolumn{2}{|c|}{ Drawdown (ft) } \\
\hline & & Upper Zone & Lower Zone & & & Upper Zone & Lower Zone \\
\hline 1:28 p.m. & \multicolumn{3}{|c|}{ Pump turned on } & 2:08 p.m. & 40 & 4.52 & 0.37 \\
\hline $1: 29$ & 1 & 3.88 & 0.01 & $2: 13$ & 45 & 4.55 & -- \\
\hline $1: 30$ & 2 & 3.92 & -- & $2: 18$ & 50 & 4.58 & -- \\
\hline $1: 31$ & 3 & 4.04 & .01 & $2: 23$ & 55 & 4.61 & -- \\
\hline $1: 32$ & 4 & 4.08 & -- & $2: 28$ & Pump shut off & 4.62 & .54 \\
\hline $1: 33$ & 5 & 4.10 & -- & $2: 29$ & 61 & .60 & -- \\
\hline $1: 34$ & 6 & 4.15 & .02 & $2: 30$ & 62 & .55 & -- \\
\hline $1: 36$ & 8 & 4.20 & .07 & $2: 31$ & 63 & .50 & .55 \\
\hline $1: 38$ & 10 & 4.24 & .10 & $2: 32$ & 64 & .47 & -- \\
\hline $1: 40$ & 12 & 4.29 & -- & $2: 33$ & 65 & .43 & -- \\
\hline $1: 42$ & 14 & 4.31 & -- & $2: 34$ & 66 & .40 & .58 \\
\hline $1: 46$ & 18 & 4.36 & .18 & $2: 35$ & 67 & .39 & -- \\
\hline $1: 48$ & 20 & 4.38 & -- & $2: 36$ & 68 & .37 & -- \\
\hline $1: 53$ & 25 & 4.42 & .26 & $2: 37$ & 69 & .35 & -- \\
\hline $1: 58$ & 30 & 4.48 & .29 & $2: 38$ & 70 & .32 & -- \\
\hline 2:03 & 35 & 4.49 & -- & 2:39 & 71 & .30 & -- \\
\hline
\end{tabular}


A constant-discharge test of the lower zone of borehole BK-2636 was also done on September 22, 1994. The packer string was lowered, and only the upper packer was inflated. The center of the packer was set at $58.0 \mathrm{ft}$ below LSD. A pump was set at $69 \mathrm{ft}$ below LSD. The initial pumping rate was less than $1.0 \mathrm{gal} / \mathrm{min}$. The pump was shut off after 12 minutes of pumping because the lower zone was dewatered.

Maximum drawdown in the lower zone was $52.8 \mathrm{ft}$. After pumping stopped, the pump was removed from the borehole, and the water in the discharge line drained out causing the slight decrease in drawdown. The lower zone recovered at a rate of $0.02 \mathrm{ft} / \mathrm{min}$, which was probably due to a small leak in the packer seal. No water-level change was measured in the upper zone. No vertical hydraulic connection between lower and upper zones was apparent. Specific capacity of the lower zone was not determined because the drawdown could be attributed to only withdrawing water from borehole storage. Drawdown in the upper and lower zones of borehole BK-2636 are listed in table 7.

Table 7. Drawdown in the upper and lower zones of borehole BK-2636 during lower-isolated-zone test on September 22, 1994, Boarhead Farms site, Bridgeton Township, Bucks County, Pa.

[ft, feet; min, minutes; --, measurement not taken]

\begin{tabular}{|c|c|c|c|}
\hline \multirow{2}{*}{ Time } & \multirow{2}{*}{$\begin{array}{l}\text { Elapsed time } \\
\text { since pumping } \\
\text { began (min) }\end{array}$} & \multicolumn{2}{|c|}{ Drawdown (ft) } \\
\hline & & Upper Zone & Lower Zone \\
\hline 3:49 p.m. & \multicolumn{3}{|c|}{ Pump turned on } \\
\hline $3: 52$ & 3 & -- & 6.0 \\
\hline 3:53 & 4 & -- & 19.60 \\
\hline 3:54 & 5 & -- & -- \\
\hline 3:55 & 6 & 0.0 & 25.90 \\
\hline 3:57 & 8 & 0.0 & 33.80 \\
\hline $3: 58$ & 9 & -- & 37.20 \\
\hline $3: 59$ & 10 & -- & 41.30 \\
\hline $4: 00$ & 11 & 0.0 & 46.70 \\
\hline 4:01 & 12 & 0.0 & 52.80 \\
\hline 4:01 & \multicolumn{3}{|c|}{ Pump shut off } \\
\hline $4: 22$ & 33 & 0.0 & 51.45 \\
\hline $4: 24$ & 34 & -- & 51.40 \\
\hline $4: 26: 30$ & 36.5 & -- & 51.32 \\
\hline $4: 29$ & 40 & -- & 51.28 \\
\hline
\end{tabular}

An isolated-zone constant-discharge test was done in the upper zone of borehole BK-2639 on September 29, 1994. A single packer was set at $47.4 \mathrm{ft}$ below LSD and a pump was set above the packer at a depth of $42 \mathrm{ft}$ below LSD. The initial pumping rate was $3.0 \mathrm{gal} / \mathrm{min}$. The rate was adjusted to $3.5 \mathrm{gal} / \mathrm{min}$ after 30 minutes of pumping and was maintained at that rate for the duration of the test. The upper zone was pumped for 50 minutes. A plot of drawdown as a function of time for the upper zone is shown figure 3 of appendix 2 .

Maximum drawdown in the upper zone was $34.68 \mathrm{ft}$, and maximum drawdown in the lower zone was $1.01 \mathrm{ft}$. The pressurization of the packer caused the $1.01 \mathrm{ft}$ water-level decline in the lower zone during the test. The water level in the upper zone recovered $5.6 \mathrm{ft}$ in 14 minutes after pumping stopped; the water level in the lower zone continued to decline, which indicates the water level in the lower zone had not stabilized before the start of the test.

No vertical hydraulic connection between the upper zone and lower zones was apparent. Specific capacity of the upper zone was $0.10(\mathrm{gal} / \mathrm{min}) / \mathrm{ft}$ after 50 minutes of pumping. 
An isolated-zone constant-discharge test of the lower zone of borehole BK-2639 was done on October 4,1994 . The packer was left in place at the same depth as for the upper zone test. The pump was set at $58 \mathrm{ft}$ below LSD. The pumping rate was $2.0 \mathrm{gal} / \mathrm{min}$. The drawdown was $35.5 \mathrm{ft}$ after 3 minutes of pumping. The pump was shut off after 3 minutes of pumping because discharge from the lower zone stopped. The water level recovered $6.5 \mathrm{ft}$ in 13 minutes. Pumping was started for a second period at a rate of $3.0 \mathrm{gal} / \mathrm{min}$. The drawdown was approximately $48 \mathrm{ft}$ below LSD after 11 minutes of pumping and the pump shut off because the lower zone was dewatered.

Maximum drawdown in the lower zone at the end of the first pumping period was $35.56 \mathrm{ft}$. A drawdown of $0.02 \mathrm{ft}$ was measured in the upper zone at the end of this period, which was probably because of a small leak in the seal of the packer. The recovery of the water level in the lower zone was probably caused by a combination of the small leak in the packer seal and water draining down the discharge hose. Maximum drawdown in the lower zone at the end of the second pumping period was $48.3 \mathrm{ft}$. An additional $0.04 \mathrm{ft}$ of water-level decline in the upper zone during the second pumping period was probably caused by a small leak in the packer seal. The water level in the lower zone did not recover after the end of the second pumping period, indicating no significant water-producing zones are below $47.4 \mathrm{ft}$ below LSD. No vertical hydraulic connection between the lower and upper zones was apparent. Specific capacity of the lower zone was not determined because the drawdown could be attributed to only withdrawing water from borehole storage.

An isolated-zone constant-discharge test was done in the upper zone of borehole BK-2640 on September 27, 1994. A single packer was set at $27.3 \mathrm{ft}$ below LSD on September 26, 1994, and left inflated overnight. The initial pumping rate was $3.75 \mathrm{gal} / \mathrm{min}$. The rate was adjusted to $3.3 \mathrm{gal} / \mathrm{min}$ after 9 minutes of pumping and was maintained at that rate for the duration of the test. The upper zone was pumped for 54 minutes. A plot of drawdown as a function of time of the upper and lower zones is shown in figure 4 of appendix 2.

Maximum drawdown in the upper zone was $5.48 \mathrm{ft}$, and maximum drawdown in the lower zone was $4.9 \mathrm{ft}$. The drawdown in the lower zone was caused by the pumping, which indicates a vertical hydraulic connection between the upper and lower parts of the borehole. Specific capacity of the upper zone was 0.60 (gal/min)/ft after 54 minutes of pumping. Drawdown in the lower zone before, during, and after pumping are listed in table 8 . The lower zone was not tested because of a vertical connection between the upper and lower parts of the borehole was established by the previous test.

An isolated-zone constant-discharge test was done in the upper zone of borehole BK-2641 on September 28,1994 . A single packer was set at $27.0 \mathrm{ft}$ below LSD and a pump was set at $22 \mathrm{ft}$ below LSD. The initial pumping rate was $1.3 \mathrm{gal} / \mathrm{min}$. The rate was increased to $3.0 \mathrm{gal} / \mathrm{min}$ after 6 minutes of pumping. The drawdown rate increased, and the pumping rate was continually decreased to a rate of $0.5 \mathrm{gal} / \mathrm{min}$, which was maintained for the duration of the test. The upper zone was pumped for 68 minutes. A plot of drawdown as a function of the time of the upper zone is shown in figure 5 of appendix 2.

Maximum drawdown in the upper zone was $21.55 \mathrm{ft}$, and maximum drawdown in the lower zone was $1.92 \mathrm{ft}$. The pressurization of the packer caused the $1.92 \mathrm{ft}$ water-level decline in the lower zone during the tests. The water level in the lower zone was $2.9 \mathrm{ft}$ higher than the water level in the upper zone after 38 minutes of stabilization time. The water level in the lower zone continued to decline throughout the duration of the test, which indicates that the water level in the lower zone had not stabilized.

No vertical hydraulic connection between the upper and lower zones was apparent. Specific capacity of the upper zone was $0.02(\mathrm{gal} / \mathrm{min}) / \mathrm{ft}$ after 68 minutes of pumping.

A constant-discharge test of the lower zone of borehole BK-2641 was done on September 29, 1994. The packer was left in place at $27.0 \mathrm{ft}$ below LSD. The pump was set at $38.6 \mathrm{ft}$ below LSD. The pumping rate was $1.5 \mathrm{gal} / \mathrm{min}$. The pump was shut off after 19 minutes of pumping because the lower zone was dewatered. 
Table 8. Drawdown in the lower zone of borehole BK-2640, September 27, 1994, Boarhead Farms site, Bridgeton Township, Bucks County, Pa.

[ft, feet; min, minutes, --, not applicable]

\begin{tabular}{cccccc}
\hline Time & $\begin{array}{c}\text { Elapsed time } \\
\text { since pumping } \\
\text { began (min) }\end{array}$ & Drawdown (ft) & Time & $\begin{array}{c}\text { Elapsed time } \\
\text { since pumping } \\
\text { began (min) }\end{array}$ & Drawdown (ft) \\
\hline 9:29 a.m. & -- & 0.0 & $10: 13$ & 44 & 4.74 \\
9:29 & Pump turned on & $10: 19$ & 50 & 4.84 \\
$9: 30$ & 1 & .28 & $10: 22$ & 52 & 4.88 \\
$9: 31$ & 2 & .78 & $10: 24$ & 54 & 4.90 \\
$9: 32$ & 3 & 1.28 & $10: 24$ & \multicolumn{2}{c}{ Pump shut off } \\
9:33 & 4 & 1.78 & $10: 25$ & 55 & 4.60 \\
$9: 34$ & 5 & 2.28 & $10: 26$ & 56 & 4.10 \\
$9: 35$ & 6 & 2.60 & $10: 27$ & 57 & 3.50 \\
$9: 36$ & 7 & 2.98 & $10: 28$ & 58 & 3.00 \\
$9: 40$ & 11 & 3.30 & $10: 29$ & 59 & 2.56 \\
9:45 & 16 & 3.88 & $10: 30$ & 60 & 2.12 \\
9:50 & 21 & 4.17 & $10: 32$ & 62 & 1.66 \\
$9: 55$ & 26 & 4.36 & $10: 34$ & 64 & 1.40 \\
10:00 & 31 & 4.52 & $10: 35$ & 65 & 1.32 \\
\hline
\end{tabular}

Maximum drawdown in the lower zone was $35.10 \mathrm{ft}$, which was at the pump intake. The water level of the lower zone did not recover. The water level of the upper zone did not change, which indicates no vertical hydraulic connection between the lower and upper zones. Specific capacity of the lower zone was not determined because the drawdown could be attributed to only withdrawing water from borehole storage. Drawdown in the lower zone are listed in table 9.

Table 9. Drawdown in the lower zone of borehole BK-2641, September 29, 1994, Boarhead Farms site, Bridgeton Township, Bucks County, Pa.

[ft, feet; min, minutes; --, measurement not taken]

\begin{tabular}{|c|c|c|}
\hline Time & $\begin{array}{l}\text { Elapsed time } \\
\text { since pumping } \\
\text { began (min) }\end{array}$ & Drawdown (ft) \\
\hline $10: 19$ & \multicolumn{2}{|c|}{ Pump turned on } \\
\hline $10: 23$ & 4 & 25.53 \\
\hline 10:26 & 7 & 34.93 \\
\hline 10:28 & 9 & 34.93 \\
\hline 10:34 & 14 & 34.90 \\
\hline 10:38 & \multicolumn{2}{|c|}{ Pump shut off } \\
\hline 10:40 & 21 & 35.10 \\
\hline 10:45 & 26 & 35.07 \\
\hline 10:49 & 30 & 35.05 \\
\hline
\end{tabular}


A constant-discharge test was done in the upper zone of borehole BK-2642 on October 4, 1994. A single packer was set at $67.9 \mathrm{ft}$ below LSD and a pump was set at a depth of $63 \mathrm{ft}$ below LSD. The initial pumping rate was $4.0 \mathrm{gal} / \mathrm{min}$. The rate was increased to $4.5 \mathrm{gal} / \mathrm{min}$ after 22 minutes of pumping and was maintained at that rate for the duration of the test. The upper zone was pumped for 72 minutes. A plot of drawdown as a function of time for the upper zone for the pumping and recovery periods is shown in figure 6 of appendix 2.

Maximum drawdown in the upper zone was $4.18 \mathrm{ft}$, and maximum drawdown in the lower zone was $0.14 \mathrm{ft}$. The pressurization of the packer caused the $0.14 \mathrm{ft}$ water-level decline in the lower zone during the test. The water level in the lower zone was $2.18 \mathrm{ft}$ higher than the water level in the upper zone after 35 minutes of stabilization time. Water levels in the lower zone were measured for 40 minutes after pumping stopped, and the levels continued to decline, which indicates that the water level in the lower zone had not stabilized.

No vertical hydraulic connection between the upper and lower zones was apparent. Specific capacity of the upper zone was 1.1 (gal/min)/ft after 72 minutes of pumping.

A constant-discharge test of the lower zone of borehole BK-2642 was done on October 5, 1994. The packer was left in place at $67.9 \mathrm{ft}$ below LSD. A pump was set at $75 \mathrm{ft}$ below LSD. The pumping rate was $3.0 \mathrm{gal} / \mathrm{min}$. The pump was shut off after 5 minutes of pumping because the lower zone was dewatered. The water level in the lower zone did not recover, indicating no significant water-producing zones are below $68 \mathrm{ft}$ below LSD.

Maximum drawdown in the lower zone was $61.37 \mathrm{ft}$. The water level in the upper zone continued to rise during the pumping of the lower zone, which indicates no vertical hydraulic connection between the lower and upper zones of the borehole. Specific capacity of the lower zone was not determined because the drawdown could be attributed to only withdrawing water from borehole storage.

An isolated-zone constant-discharge test was done in the upper zone of borehole BK-2643 on October 5, 1994. A single packer was set at $26.6 \mathrm{ft}$ below LSD and a pump was set at approximately $22 \mathrm{ft}$ below LSD. The initial pumping rate was $2.5 \mathrm{gal} / \mathrm{min}$. The rate was decreased to $1.7 \mathrm{gal} / \mathrm{min}$ after 5 minutes of pumping and was maintained at that rate for the duration of the test. The discharge rate declined throughout the test because of rapid drawdown. The pump was shut off after 35 minutes of pumping because the upper zone was dewatered.

Maximum drawdown in the upper zone at the end of pumping was $21.24 \mathrm{ft}$, which was at the pump intake, and the maximum drawdown in the lower zone was $0.13 \mathrm{ft}$. The pressurization of the packer caused the $0.13 \mathrm{ft}$ water-level decline in the lower zone during the test. The water level in the lower zone continued to decline after the pump was shut off, while the water level in the upper zone recovered at a rate of $0.01 \mathrm{ft} / \mathrm{min}$. No vertical hydraulic connection between the upper and lower zones was apparent. Specific capacity of the upper zone was not determined because the drawdown could be attributed to only withdrawing water from borehole storage.

A constant-discharge test of the lower zone of borehole BK-2643 was also done on October 5, 1994. The packer was left in place at $26.6 \mathrm{ft}$ below LSD. The pump was set at $38 \mathrm{ft}$ below LSD. The water level in the upper zone was $20.41 \mathrm{ft}$ below LSD and was not fully recovered from the test of the upper zone. The initial pumping rate was $2.0 \mathrm{gal} / \mathrm{min}$. The rate was increased to $2.75 \mathrm{gal} / \mathrm{min}$ after 32 minutes of pumping and was maintained at that rate for the duration of the test. The lower zone was pumped for 68 minutes. A plot of drawdown as a function of time for the lower zone is shown in figure 7 of appendix 2.

Maximum drawdown in the lower zone was $25.16 \mathrm{ft}$. The water level in the upper zone continued to rise during pumping of the lower zone. Specific capacity of the lower zone was $0.11(\mathrm{gal} / \mathrm{min}) / \mathrm{ft}$ after 68 minutes of pumping.

No vertical hydraulic connection between the lower and upper zones of the borehole was apparent. The water level in the upper zone recovered $0.54 \mathrm{ft}$ during the 94-minute pumping and recovery period of the lower zone test. BK-2643 is the only borehole on the site where the primary water-producing fracture was in the lower zone. 


\section{Open-Hole Constant-Disc harge Tests}

Open-hole constant-discharge tests were done in boreholes with reported yields greater than $1.0 \mathrm{gal} / \mathrm{min}$, which included BK-2632, BK-2636, BK-2638, BK-2639, BK-2640, BK-2641, and BK-2643. Transmissivities ranged from 3.1 to $100 \mathrm{ft}^{2} /$ day with a median of $50 \mathrm{ft}^{2} /$ day. Results from tests in boreholes BK-2638 and BK-2641 were not used in determining the median transmissivity because transmissivities could not be determined. Transmissivities from the open-hole constant-discharge tests are summarized in table 10.

Table 10. Pumping rate, pumping duration, and transmissivity for open-hole constant-discharge tests, Boarhead Farms site, Bridgeton Township, Bucks County, Pa.

[USGS, U.S. Geological Survey; ft, feet; gal/min, gallons per minute; min, minutes; $\mathrm{ft}^{2} /$ day, square feet per day; --, not determined]

\begin{tabular}{ccccc}
\hline $\begin{array}{c}\text { USGS } \\
\text { identification } \\
\text { number }\end{array}$ & Date of test & $\begin{array}{c}\text { Pumping } \\
\text { rate } \\
\text { (gal/min) }\end{array}$ & $\begin{array}{c}\text { Pumping } \\
\text { duration } \\
(\mathrm{min})\end{array}$ & $\begin{array}{c}\text { Transmissivity } \\
\left(\mathrm{ft}^{2} / \text { day }\right)\end{array}$ \\
\hline BK-2632 & October 27, 1994 & 1.0 & 240 & 3.1 \\
BK-2636 & October 26, 1994 & 6.0 & 450 & 100 \\
BK-2638 & October 24, 1994 & 9.0 & 335 & -- \\
BK-2639 & October 19, 1994 & 2.5 & 67 & 50 \\
BK-2640 & October 18, 1994 & 3.2 & 240 & 83 \\
BK-2641 & October 28, 1994 & 1.0 & 160 & -- \\
BK-2643 & October, 20 1994 & 1.9 & 240 & 12 \\
\hline
\end{tabular}

An open-hole constant-discharge test was done in borehole BK-2632 on October 27,1994. A submersible pump was set at a depth of $32 \mathrm{ft}$ below LSD. Water-level response to the pumping stress was measured in the pumped borehole and four observation boreholes BK-2631, BK-2633, BK-2643, and BK-2707 (table 11). BK-2631 is about $145 \mathrm{ft}$ southwest of BK-2632, BK-2633 and BK-2643 are $80 \mathrm{ft}$ east of BK-2632, and BK-2707 is $150 \mathrm{ft}$ southwest of BK-2632 (fig. 10). The pumping rate for the test was $1.0 \mathrm{gal} / \mathrm{min}$. The test duration was 240 minutes.

A plot of logarithm of drawdown as a function of the logarithm of time overlain by the type-curve $\mathrm{F}(\mu, \alpha)$ versus $1 / \mu$ with $\alpha$ equal to 0.1 is shown in figure 11 . An acceptable match to the type curve was apparent between elapsed time 200-10,000 seconds, and a match point was chosen to estimate transmissivity. The early-time part of the plot shows more drawdown than would be predicted by the type curve. The deviation from the type curve could be the result of drill cuttings filling fractures near the well bore and decreasing permeability, which can effect the early-time data. The early-time data were not used in the curve match analyses. The late-time part of the graph (time greater than 10,000 seconds) is flat and deviates from the type curve. The deviation is probably because of a slight decrease in the pumping rate. Transmissivity determined from the open-hole constant-discharge test for borehole BK-2632 is $3.1 \mathrm{ft}^{2} /$ day. The pumping stress had no apparent effect on the water levels in any of the observation boreholes (table 11) indicating that no significant hydraulic connection exists between BK-2632 and observation boreholes BK-2631, BK-2633, BK-2643, and BK-2707. The estimated discharge rate adjusted to an 8-hour pumping period is $0.3 \mathrm{gal} / \mathrm{min}$. Borehole BK-2632 could be pumped at a rate of $0.3 \mathrm{gal} / \mathrm{min}$ for 8 hours without dewatering the borehole.

An open-hole constant-discharge test was done in borehole BK-2636 on October 26, 1994. A submersible pump was set at a depth of approximately $39 \mathrm{ft}$ below LSD. Water-level response to the pumping stress was measured in the pumped borehole and five observation boreholes, BK-2635, BK-2637, BK-2638, BK-2706, and BK-2708 (table 12). BK-2635 is about $105 \mathrm{ft}$ west of BK-2636, BK-2637 is $100 \mathrm{ft}$ 


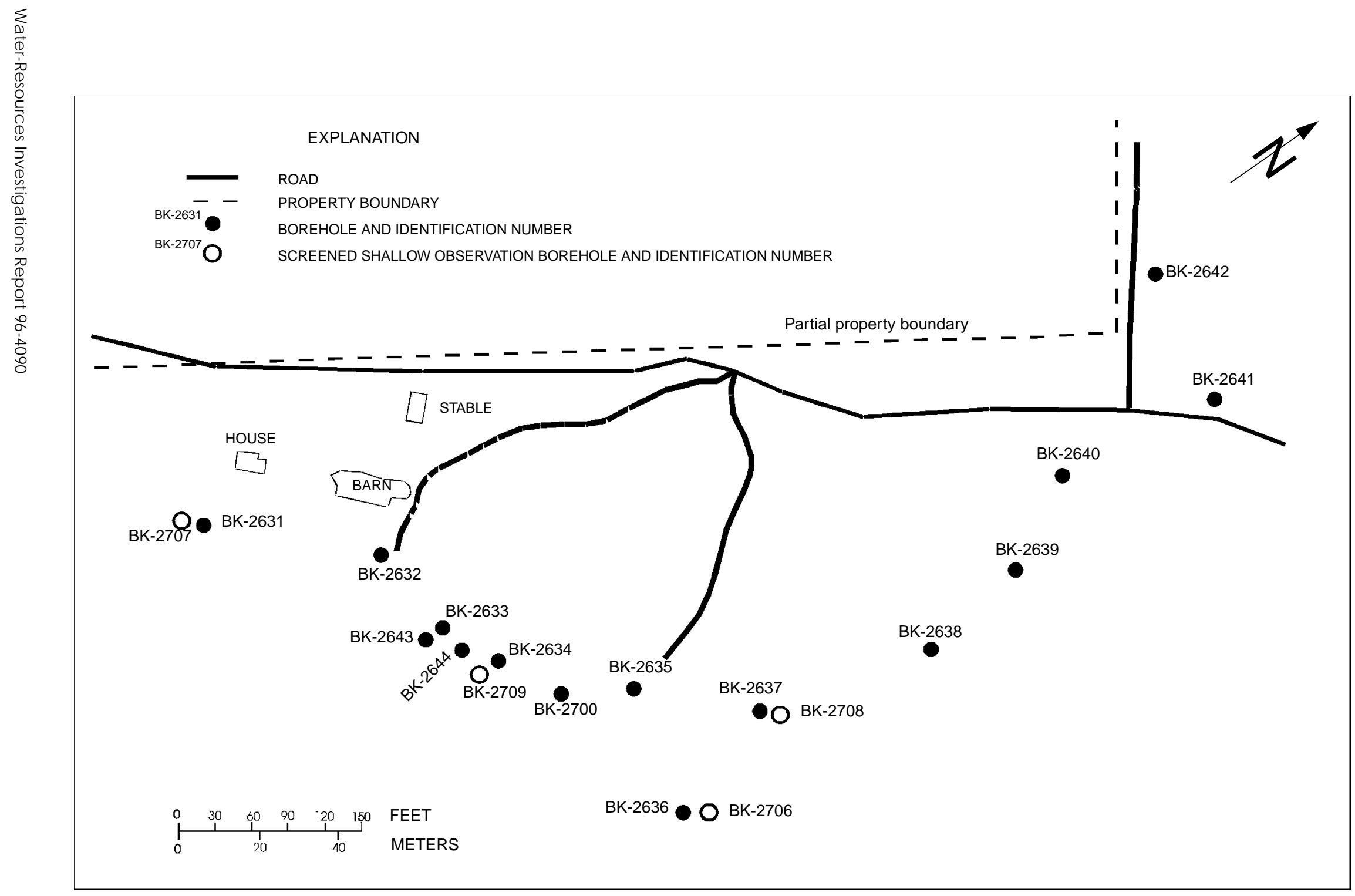

Figure 10. Boreholes used for open-hole constant-discharge tests, Boarhead Farms site, Bridgeton Township, Bucks County, Pa. 


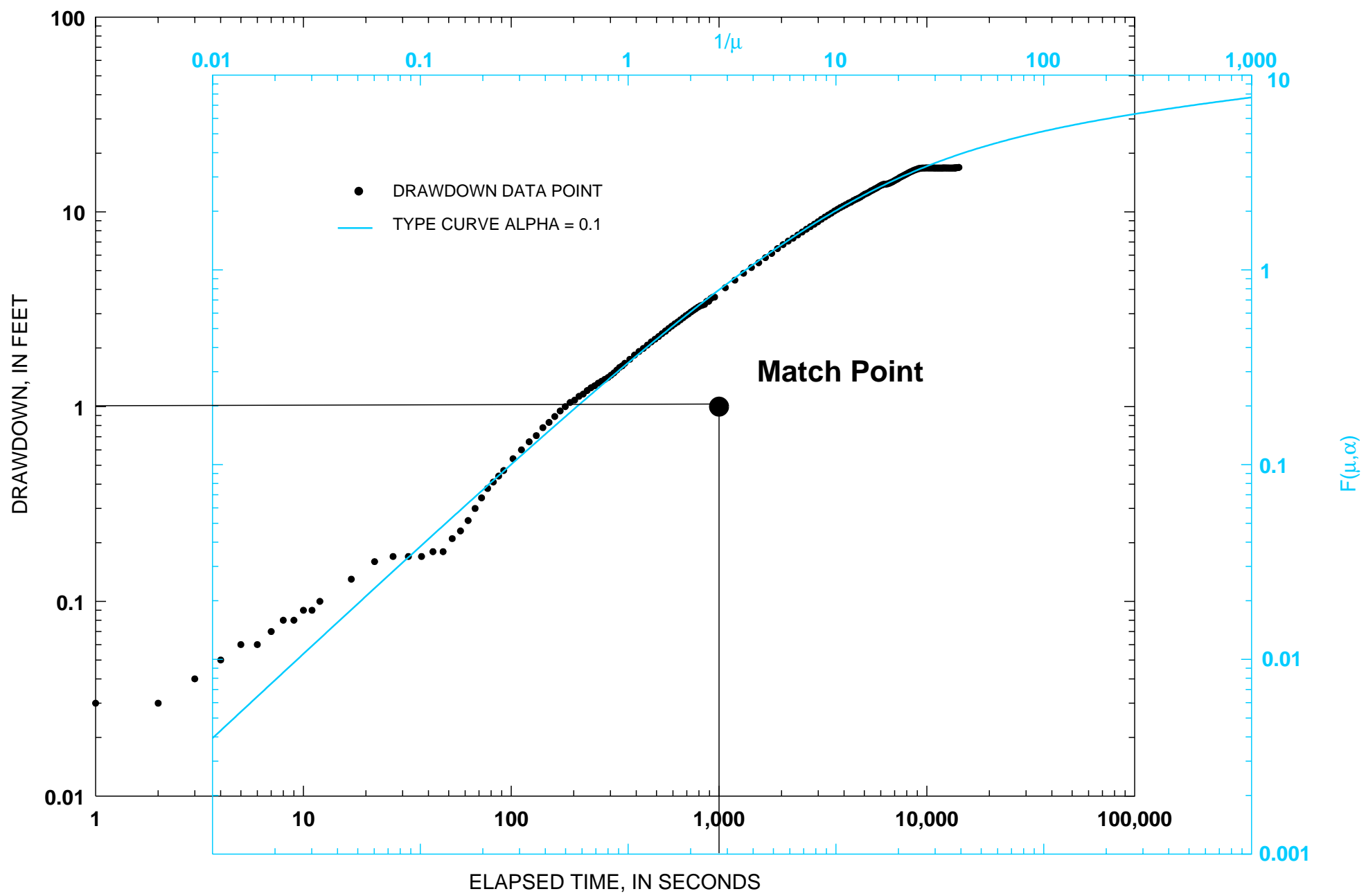

Figure 11. Logarithm of drawdown versus logarithm of time and corresponding type curve with match point for open-hole constantdischarge test of borehole BK-2632 on October 27, 1994, Boarhead Farms site, Bridgeton Township, Bucks County, Pa. 
Table 11. Water-level measurements in observation boreholes BK-2631, BK-2633, BK-2643, and BK-2707 during open-hole constant-discharge test of borehole BK-2632, October 27, 1994, Boarhead Farms site, Bridgeton Township, Bucks County, Pa.

[min, minutes; --, measurement not taken]

\begin{tabular}{lccccc}
\hline \multirow{2}{*}{ Time } & $\begin{array}{c}\text { Elapsed time } \\
\text { since pumping } \\
\text { began (min) }\end{array}$ & \multicolumn{5}{c}{ Depth to water, in feet below top of casing } \\
\cline { 3 - 6 } 10:00 a.m. & -- & 5.94 & BK-2631 & BK-2643 & BK-2707 \\
11:00 & & & Pump turned on & 4.73 & 5.53 \\
$11: 01$ & 1 & 5.95 & 4.12 & 4.75 & 5.56 \\
$11: 17$ & 17 & 5.95 & -- & -- & 5.56 \\
$11: 23$ & 23 & -- & 4.12 & 4.74 & -- \\
12:05 p.m. & 65 & 5.95 & 4.13 & 4.74 & 5.55 \\
12:42 & 102 & 5.95 & 4.12 & 4.74 & 5.54 \\
1:30 & 150 & 5.94 & 4.13 & 4.72 & 5.53 \\
2:12 & 192 & 5.94 & 4.13 & 4.72 & 5.53 \\
2:48 & 228 & 5.93 & 4.12 & 4.72 & 5.53 \\
3:00 & & & Pump shut off & & \\
3:53 & 293 & 5.94 & 4.11 & 4.71 & 5.54 \\
\hline
\end{tabular}

northwest of BK-2636, BK-2638 is $235 \mathrm{ft}$ north of BK-2636, BK-2706 is $15 \mathrm{ft}$ east of BK-2636, and BK-2708 is $100 \mathrm{ft}$ northwest of BK-2636 (fig. 10). The pumping rate for the test was $6.0 \mathrm{gal} / \mathrm{min}$. The test duration was 450 minutes.

Figure 1 of appendix 3 shows the plot of logarithm of drawdown as a function of the logarithm of time overlain by the type curve $\mathrm{F}(\mu, \alpha)$ versus $1 / \mu$ with $\alpha$ equal to 0.01 . An acceptable match to the type curve was apparent between elapsed time 100-7,000 seconds, and a match point was chosen to estimate transmissivity. The early-time part of the plot is a straight line, which indicates borehole-storage effects. Transmissivity determined from the open-hole constant-discharge test for borehole BK-2636 is $100 \mathrm{ft}^{2} /$ day. Observation borehole BK-2706, which is completed in the weathered bedrock zone, was the only observation borehole affected by the pumping stress suggesting a hydraulic connection exists between these boreholes. The pumping stress had no effect on the water levels in observation boreholes BK-2635, BK-2637, BK-2638, and BK-2708 (table 12). The estimated discharge rate adjusted to an 8-hour pumping period is $7.5 \mathrm{gal} / \mathrm{min}$. Borehole BK-2636 could be pumped at a rate of $7.5 \mathrm{gal} / \mathrm{min}$ for 8 hours without dewatering the borehole.

An open-hole constant-discharge test was done in borehole BK-2638 on October 24, 1994. A submersible pump was set at a depth of $35 \mathrm{ft}$ below LSD. Water-level response to the pumping stress was measured in the pumped borehole and four observation boreholes, BK-2635, BK-2636, BK-2639, and BK-2640 (table 13). Borehole BK-2635 is about $235 \mathrm{ft}$ southwest of BK-2638, BK-2636 is $235 \mathrm{ft}$ south of BK-2638, BK-2639 is $95 \mathrm{ft}$ north of BK-2638, and BK-2640 is $175 \mathrm{ft}$ north of BK-2638 (fig. 10). The pumping rate for the test was $9.0 \mathrm{gal} / \mathrm{min}$. The test was originally designed for a 480 minute pumping period; however, the fracture system was dewatered, and the pumping water level fell below the pump intake after 335 minutes. Because the data logger malfunctioned, all drawdown data were lost. The test was not re-run because the fracture system was dewatered and the treatment of discharge water was costly. Data collection was complete in the observation boreholes, and no drawdown was measured indicating no apparent hydraulic connection exists between borehole BK-2638 and observation boreholes BK-2635, BK-2636, BK-2639, and BK-2640. An 8-hour estimated discharge rate could not be determined. 
Table 12. Water-level measurements in observation boreholes BK-2706, BK-2635, BK-2637, BK-2638, and BK-2708 during open-hole constant-discharge test of borehole BK-2636, October 26, 1994, Boarhead Farms site, Bridgeton Township, Bucks County, Pa.

[min, minutes; --, measurement not taken]

\begin{tabular}{|c|c|c|c|c|c|c|}
\hline \multirow{2}{*}{ Time } & \multirow{2}{*}{$\begin{array}{l}\text { Elapsed time } \\
\text { since pumping } \\
\text { began (min) }\end{array}$} & \multicolumn{5}{|c|}{ Depth to water, in feet below top of casing } \\
\hline & & BK-2706 & BK-2635 & BK-2637 & BK-2638 & BK-2708 \\
\hline 8:05 a.m. & -- & 2.69 & 11.32 & 9.83 & -- & 8.07 \\
\hline 9:20 & -- & -- & 11.34 & 9.84 & -- & 8.10 \\
\hline 9:30 & \multicolumn{6}{|c|}{ Pump turned on } \\
\hline 9:35 & 5 & 2.96 & -- & -- & -- & -- \\
\hline $9: 39$ & 9 & 3.14 & 11.33 & 9.83 & -- & 8.10 \\
\hline 9:50 & 20 & 3.40 & -- & -- & -- & -- \\
\hline 10:00 & 30 & 3.59 & 11.34 & 9.84 & 6.89 & 8.11 \\
\hline 10:15 & 45 & 3.76 & 11.34 & 9.83 & 6.89 & 8.11 \\
\hline $10: 30$ & 60 & 3.85 & 11.33 & 9.84 & -- & 8.11 \\
\hline $10: 46$ & 76 & 3.93 & 11.33 & 9.84 & -- & 8.12 \\
\hline $11: 20$ & 110 & 4.03 & 11.33 & 9.83 & -- & 8.11 \\
\hline $11: 45$ & 135 & 4.06 & -- & -- & -- & -- \\
\hline $11: 53$ & 143 & -- & 11.33 & 9.83 & -- & 8.11 \\
\hline 12:38 p.m. & 188 & 4.13 & 11.34 & 9.83 & -- & 8.09 \\
\hline $1: 29$ & 239 & -- & 11.33 & 9.81 & 6.80 & 8.11 \\
\hline $1: 47$ & 257 & 4.20 & -- & -- & -- & -- \\
\hline $2: 11$ & 281 & -- & 11.34 & 9.82 & -- & 8.10 \\
\hline $2: 50$ & 320 & 4.24 & 11.33 & 9.81 & -- & 8.13 \\
\hline $3: 30$ & 360 & 4.27 & 11.32 & 9.80 & 6.77 & 8.15 \\
\hline $4: 30$ & 420 & 4.31 & 11.33 & 9.80 & 6.75 & 8.15 \\
\hline $4: 57$ & 447 & -- & 11.31 & 9.80 & -- & 8.19 \\
\hline $5: 00$ & \multicolumn{6}{|c|}{ Pump shut off } \\
\hline 5:15 & 465 & -- & 11.31 & 9.79 & -- & 8.20 \\
\hline
\end{tabular}

An open-hole constant-discharge test was done in borehole BK-2639 on October 19, 1994. A submersible pump was set at a depth of approximately $38 \mathrm{ft}$ below LSD. Water-level response to the pumping stress was measured in the pumped borehole and two observation boreholes BK-2638 and BK-2640 (table 14). BK-2638 is about $95 \mathrm{ft}$ south of BK-2639 and BK-2640 is $85 \mathrm{ft}$ northwest of BK-2639 (fig. 10). The pumping rate for the test was $2.5 \mathrm{gal} / \mathrm{min}$. A pumping period of 240 minutes was originally planned; however, the fracture system was dewatered and the pumping water level fell below the pump intake after 65 minutes.

Figure 2 of appendix 3 shows the plots of logarithm of drawdown as a function of the logarithm of time overlain by the type-curve $F(\mu, \alpha)$ versus $1 / \mu$ with $\alpha$ equal to 0.001 . An acceptable match to the type curve was apparent between 200-900 seconds of pumping, and a match point was chosen to estimate transmissivity. The early-time part of the plot shows more drawdown than would be predicted by the type curve. The deviation from the type curve could be the result of drill cuttings filling fractures near the well bore and decreasing permeability, which can effect the early-time data. The early-time data were not used in the curve match analyses. The late-time part of the logarithm drawdown versus logarithm time plot 
Table 13. Water-level measurements in observation boreholes BK-2635, BK-2636, BK-2639, and BK-2640 during open-hole constant-discharge test of borehole BK-2638, October 24, 1994, Boarhead Farms site, Bridgeton Township, Bucks County, Pa.

[min, minutes; --, measurement not taken]

\begin{tabular}{|c|c|c|c|c|c|}
\hline \multirow{2}{*}{ Time } & \multirow{2}{*}{$\begin{array}{l}\text { Elapsed time } \\
\text { since pumping } \\
\text { began (min) }\end{array}$} & \multicolumn{4}{|c|}{ Depth to water, in feet below top of casing } \\
\hline & & BK-2635 & BK-2636 & BK-2639 & BK-2640 \\
\hline 8:10 a.m. & -- & -- & -- & 6.87 & -- \\
\hline $9: 30$ & \multicolumn{5}{|c|}{ Pump turned on } \\
\hline $11: 00$ & 90 & -- & 1.42 & 6.88 & 4.97 \\
\hline $11: 40$ & 130 & 11.42 & 1.45 & 6.84 & 4.96 \\
\hline 12:10 p.m. & 160 & 11.42 & 1.43 & 6.83 & 4.94 \\
\hline $1: 00$ & 210 & 11.43 & 1.42 & 6.80 & 4.91 \\
\hline $1: 50$ & 260 & 11.43 & 1.41 & 6.78 & 4.89 \\
\hline $2: 36$ & 306 & 11.43 & 1.40 & 6.77 & 4.87 \\
\hline 3:05 & \multicolumn{5}{|c|}{ Pump shut off } \\
\hline $3: 10$ & 340 & 11.42 & 1.40 & 6.77 & 4.87 \\
\hline
\end{tabular}

(time greater than 900 seconds) is a straight line with an increasing slope that deviates from the type curve. The deviation probably is because of a dewatering of the water-bearing zone, and the drawdown represents only water pumped from well-bore storage.

Transmissivity for borehole BK-2639 determined before the water-bearing fractures were dewatered is $50 \mathrm{ft}^{2} /$ day. The pumping stress had no effect on the water levels in observation boreholes BK-2638 and BK-2640 (table 14). No hydraulic connection exists between BK-2639 and observation boreholes BK-2638 and BK-2640. Since the primary water-bearing fractures were dewatered, an 8-hour estimated discharge rate was not determined.

Table 14. Water-level measurements in boreholes BK-2638 and

BK-2640 during open-hole constant-discharge test of borehole

BK-2639, October 19, 1994, Boarhead Farms site, Bridgeton

Township, Bucks County, Pa.

[min, minutes; --, measurement not taken]

\begin{tabular}{cccc}
\hline \multirow{2}{*}{ Time } & $\begin{array}{c}\text { Elapsed time } \\
\text { since pumping } \\
\text { began (min) }\end{array}$ & \multicolumn{2}{c}{$\begin{array}{c}\text { Depth to water, in feet below top of } \\
\text { casing }\end{array}$} \\
\cline { 3 - 4 } & & BK-2638 & BK-2640 \\
\hline 8:10 a.m. & -- & 6.71 & -- \\
9:40 & -- & -- & -- \\
9:45 & & Pump turned on & \\
10:00 & 15 & -- & 5.38 \\
10:15 & 30 & -- & 5.38 \\
10:49 & 64 & -- & 5.37 \\
10:52 & & Pump shut off & \\
11:25 & 100 & 6.69 & -- \\
\hline
\end{tabular}


An open-hole constant-discharge test was done in borehole BK-2640 on October 18,1994. A submersible pump was set at a depth of approximately $29 \mathrm{ft}$ below LSD. Water-level response to the pumping stress was measured in the pumped borehole and three observation boreholes, BK-2639, BK-2641 and BK-2642 (table 15). BK-2639 is about $85 \mathrm{ft}$ southeast of BK-2640, BK-2641 is $135 \mathrm{ft}$ north of BK-2640, and BK-2642 is $180 \mathrm{ft}$ northwest of BK-2640 (fig. 10). The pumping rate for the test was $3.2 \mathrm{gal} / \mathrm{min}$. The test duration was 240 minutes.

Table 15. Water-level measurements in observation boreholes BK-2639, BK-2641, and BK-2642 during open-hole constant-discharge test of borehole BK-2640, October 18, 1994, Boarhead Farms site, Bridgeton Township, Bucks County, Pa.

[min, minutes; --, measurement not taken]

\begin{tabular}{ccccc}
\hline \multirow{2}{*}{ Time } & $\begin{array}{c}\text { Elapsed time } \\
\text { since pumping } \\
\text { began (min) }\end{array}$ & \multicolumn{3}{c}{ Depth to water, in feet below top of casing } \\
\cline { 3 - 5 } 8:30 a.m. & -- & 7.03 & BK-2641 & BK-2642 \\
8:59 & -- & 7.03 & 5.20 & -- \\
9:00 & & \multicolumn{2}{c}{ Pump turned on } & -- \\
9:15 & 15 & 7.03 & 5.20 & -- \\
9:30 & 30 & 7.03 & 5.20 & 5.22 \\
10:00 & 60 & 7.03 & 5.19 & 5.21 \\
10:20 & 80 & 7.03 & 5.20 & 5.22 \\
10:40 & 100 & 7.02 & 5.20 & 5.21 \\
11:00 & 120 & 7.02 & 5.19 & 5.21 \\
11:25 & 145 & 7.01 & 5.19 & 5.20 \\
11:40 & 160 & 7.01 & 5.19 & 5.19 \\
12:00 p.m. & 180 & 7.01 & 5.18 & 5.19 \\
12:45 & 225 & 7.01 & 5.17 & 5.17 \\
1:00 & & \multicolumn{2}{c}{ Pump shut off } \\
1:04 & 244 & 7.00 & 5.17 & \\
1:50 & 290 & 6.98 & -- & 5.16 \\
\hline
\end{tabular}

Figure 3 of appendix 3 shows the plot of logarithm of drawdown versus logarithm of time overlain by the type-curve $F(\mu, \alpha)$ versus $1 / \mu$ with $\alpha$ equal to 0.01 . An acceptable match to the type curve was apparent between elapsed time 200-2,000 seconds, and a match point was chosen to estimate transmissivity. The slope of the graph for the late-time part of the logarithm drawdown versus logarithm time plot (time greater than 10,000 seconds) is increasing and may indicate the dewatering of the fracture system supplying water to the borehole. Transmissivity determined from the open-hole constant-discharge test for borehole BK-2640 is $83 \mathrm{ft}^{2} /$ day. The pumping stress had no effect on the water levels in any of the observation boreholes (table 15). No apparent hydraulic connection exists between BK-2640 and observation boreholes BK-2639, BK-2641, and BK-2642. The estimated discharge rate adjusted to an 8-hour pumping period is $7.7 \mathrm{gal} / \mathrm{min}$. Borehole BK-2640 could be pumped at a rate of $7.7 \mathrm{gal} / \mathrm{min}$ for 8 hours without dewatering the borehole.

An open-hole constant-discharge test was done in borehole BK-2641 on October 28, 1994. A submersible pump was set at a depth of approximately $32 \mathrm{ft}$ below LSD. Water-level response to the pumping stress was measured in the pumped borehole and two observation boreholes BK-2640 and BK-2642 (table 16). BK-2640 is $135 \mathrm{ft}$ south of BK-2641, and BK-2642 is $115 \mathrm{ft}$ west of BK-2641 (fig. 10). The 
pumping rate for the test was $1.0 \mathrm{gal} / \mathrm{min}$. A pumping period of 240 minutes was originally planned; however, the fracture system was dewatered and the pumping water level fell below the pump intake after 160 minutes.

Figure 4 of appendix 3 shows the plot of logarithm of drawdown as a function of the logarithm of time. A deviation from the straight line after 4,500 seconds of pumping was the result of a slight decrease in the pumping rate. No acceptable match to the type curves was apparent, and transmissivity could not be calculated. Most of the plot is a straight line, indicating water only is being removed from well-bore storage, and no water from the formation is entering the borehole. An 8-hour estimated discharge rate could not be determined.

Table 16. Water-level measurements in observation boreholes BK-2640 and BK-2642 during open-hole constant-discharge test of borehole BK-2641, October 28, 1994, Boarhead Farms site, Bridgeton Township, Bucks County, $\mathrm{Pa}$.

[min, minutes; --, measurement not taken]

\begin{tabular}{|c|c|c|c|}
\hline \multirow{2}{*}{ Time } & \multirow{2}{*}{$\begin{array}{l}\text { Elapsed time } \\
\text { since pumping } \\
\text { began (min) }\end{array}$} & \multicolumn{2}{|c|}{$\begin{array}{c}\text { Depth to water, in feet below top o } \\
\text { casing }\end{array}$} \\
\hline & & BK-2640 & BK-2642 \\
\hline 8:35 a.m. & -- & -- & 3.80 \\
\hline $8: 50$ & & Pump turned on & \\
\hline 9:08 & 18 & 4.72 & -- \\
\hline $9: 40$ & 50 & 4.73 & 3.82 \\
\hline $10: 20$ & 90 & 4.72 & 3.81 \\
\hline $10: 55$ & 125 & -- & 3.81 \\
\hline 11:05 & 135 & 4.71 & -- \\
\hline $11: 30$ & & Pump shut off & \\
\hline $11: 35$ & 165 & 4.71 & 3.80 \\
\hline
\end{tabular}

An open-hole constant-discharge test was done in borehole BK-2643 on October 20,1994. A submersible pump was set at a depth of approximately $28 \mathrm{ft}$ below LSD. Water-level response to the pumping stress was measured in the pumped borehole and five observation boreholes, BK-2632, BK-2633, BK-2634, BK-2644, and BK-2709 (table 17). BK-2632 is about $80 \mathrm{ft}$ west of BK-2643, BK-2633 is $25 \mathrm{ft}$ north of BK-2643, BK-2634 is $60 \mathrm{ft}$ northeast of BK-2643, BK-2644 is $45 \mathrm{ft}$ northeast of BK-2643, and BK-2709 is $60 \mathrm{ft}$ northeast of BK-2643 (fig. 10). The pumping rate for the test was $1.9 \mathrm{gal} / \mathrm{min}$. The test duration was 240 minutes.

Figure 5 of appendix 3 shows the plot of logarithm of drawdown as a function of the logarithm of time for the pumped borehole BK-2643 and observation borehole BK-2633 with the type curve $\mathrm{F}(\mu, \alpha)$ versus $1 / \mu$ with $\alpha$ equal to 0.01 overlain on the plot for the pumped borehole. An acceptable match between the plot for the pumped borehole and the type curve was apparent between elapsed time 20010,000 seconds of pumping, and a match point was chosen to estimate transmissivity. The early-time part of the plot for the pumped borehole shows more drawdown than would be predicted by the type curve. The deviation from the type curve could be the result of drill cuttings filling fractures near the well bore and decreasing permeability, which can effect the early-time data. The early-time data were not used in the curve match analyses. Transmissivity determined from the open-hole constant-discharge test for borehole BK-2643 is $12 \mathrm{ft}^{2} /$ day. The pumping stress had no effect on the water levels in observation boreholes BK-2632, BK-2634, BK-2644, and BK-2709 (table 17). The estimated discharge rate adjusted to an 8-hour pumping period is $1.4 \mathrm{gal} / \mathrm{min}$. Borehole BK-2643 could be pumped at a rate of $1.4 \mathrm{gal} / \mathrm{min}$ for 8 hours without dewatering the borehole. 
Observation borehole BK-2633 was affected by the pumping of borehole BK-2643, and a hydraulic connection exists between these boreholes. The water level in borehole BK-2633 declines at a steady rate during the pumping period (table 17). The maximum drawdown in borehole BK-2633 after 240 minutes is $7.2 \mathrm{ft}$. However, the water-level declined an additional $0.7 \mathrm{ft}$ after pumping stopped and did not recover for an additional 50 minutes (fig. 5 of appendix 3). This response could be attributable to the depth of the interconnected fracture system between these two boreholes. The depth of the fracture system is most likely just below the casing. Once the water level in the pumped borehole fell below the elevation of the connecting fracture system, the water in the fracture system of borehole BK-2633 continually drained at a constant rate until the water level in the pumped borehole recovered to the elevation of the connecting fracture system.

Table 17. Water-level measurements in observation boreholes BK-2632, BK-2633, BK-2634, BK-2644, and BK-2709 during open-hole constant-discharge test of borehole BK-2643, October 20, 1994, Boarhead Farms site, Bridgeton Township, Bucks County, Pa.

[min, minutes; --, measurement not taken]

\begin{tabular}{|c|c|c|c|c|c|c|}
\hline \multirow{2}{*}{ Time } & \multirow{2}{*}{$\begin{array}{l}\text { Elapsed time } \\
\text { since pumping } \\
\text { began (min) }\end{array}$} & \multicolumn{5}{|c|}{ Depth to water, in feet below top of casing } \\
\hline & & BK-2632 & BK-2633 & BK-2634 & BK-2644 & BK-2709 \\
\hline 8:00 a.m. & -- & 8.61 & 4.43 & 9.39 & 5.34 & 9.20 \\
\hline 9:30 & -- & -- & 4.38 & 9.40 & 5.34 & 9.23 \\
\hline $9: 35$ & \multicolumn{6}{|c|}{ Pump turned on } \\
\hline $9: 45$ & 10 & -- & 4.50 & 9.40 & 5.34 & 9.21 \\
\hline 10:00 & 25 & -- & 4.88 & 9.40 & 5.34 & 9.21 \\
\hline 10:15 & 40 & -- & 5.34 & 9.39 & 5.34 & 9.21 \\
\hline 10:30 & 55 & -- & 5.83 & 9.40 & 5.34 & 9.21 \\
\hline 10:45 & 70 & -- & 6.34 & 9.40 & 5.34 & 9.21 \\
\hline 11:00 & 85 & -- & 6.87 & 9.40 & 5.34 & 9.21 \\
\hline $11: 20$ & 105 & -- & 7.54 & 9.40 & 5.34 & 9.21 \\
\hline 11:40 & 125 & -- & 8.30 & 9.40 & 5.34 & 9.21 \\
\hline 12:00 p.m. & 145 & -- & 8.94 & 9.40 & 5.34 & 9.21 \\
\hline $12: 20$ & 165 & -- & 9.58 & 9.40 & 5.34 & 9.21 \\
\hline $12: 40$ & 185 & -- & 10.18 & 9.40 & 5.34 & 9.21 \\
\hline 1:00 & 205 & -- & 10.74 & 9.40 & 5.34 & 9.21 \\
\hline $1: 10$ & 215 & 8.61 & -- & -- & -- & -- \\
\hline $1: 20$ & 225 & -- & 11.32 & 9.40 & 5.34 & 9.21 \\
\hline $1: 30$ & 235 & -- & 11.62 & 9.40 & 5.34 & 9.21 \\
\hline $1: 35$ & \multicolumn{6}{|c|}{ Pump shut off } \\
\hline $1: 45$ & 250 & -- & 11.90 & 9.40 & 5.34 & 9.21 \\
\hline $2: 00$ & 265 & 8.62 & 12.14 & 9.40 & 5.34 & 9.21 \\
\hline $2: 55$ & 320 & 8.61 & 11.95 & 9.40 & 5.35 & 9.21 \\
\hline 3:35 & 360 & -- & 11.22 & 9.40 & 5.35 & 9.21 \\
\hline
\end{tabular}




\section{SUMMARY AND CONCLUSIONS}

The Boarhead Farms site is underlain by a diabase aquifer that is comprised of a shallow and areally limited fracture system that is poorly connected and low yielding with little to no ground-water storage in a thin overburden soil and weathered bedrock zone. The thickness of the overburden soil ranges from 4 to $14 \mathrm{ft}$. The overburden soil has a high clay content and acts as a confining unit for the underlying bedrock aquifer. A weathered bedrock zone that consists of broken diabase ranged from 2 to $15 \mathrm{ft}$ thick. The openings in the weathered bedrock zone were filled with clay. Because of the clay-rich overburden soil and the thin, clay filled weathered bedrock zone, little ground-water storage is available to supply the shallow fracture systems. No water-producing fractures were penetrated at depths greater than about $50 \mathrm{ft}$ below land surface.

In seven of the eight boreholes in which isolated-zone constant-discharge tests were completed, no vertical connections existed between the upper and lower zones of the boreholes. A hydraulic connection exists between the upper and lower zones of borehole BK-2640.

Little or no hydraulic connection exists between adjacent boreholes. A hydraulic connection is present between boreholes BK-2636 and BK-2706, which are $15 \mathrm{ft}$ apart. A hydraulic connection is present between boreholes BK-2643 and BK-2633, which are $25 \mathrm{ft}$ apart. No drawdown was measured in any observation borehole that was $45 \mathrm{ft}$ or more from a pumping borehole during the open-hole constant-discharge tests. No hydraulic connection was observed between boreholes BK-2632, BK-2638, BK-2639, BK-2640, and BK-2641 and nearby observation boreholes during open-hole constant-discharge tests.

Transmissivities determined from five open-hole constant-discharge tests ranged from 3.1 to $100 \mathrm{ft}^{2} /$ day with a median of $50 \mathrm{ft}^{2} /$ day. Estimated discharge rates adjusted to a common 8-hour pumping period are 0.3, 7.5, 7.7, and $1.4 \mathrm{gal} / \mathrm{min}$ for boreholes BK-2632, BK-2636, BK-2640, and BK-2643, respectively. These boreholes could be pumped at these rates for an 8-hour period without dewatering.

During open-hole constant-discharge tests of boreholes BK-2638, BK-2639, and BK-2641, the fracture systems were dewatered, which indicates the fracture systems supplying water to these boreholes are limited in areal extent. Estimated 8-hour discharge rates for these boreholes were not determined. 


\section{REFERENCES CIED}

Cooper, H.H., Jr., Bredehoeft, J.D., and Papadopulos, I.S., 1967, Response of a finite-diameter well to an instantaneous charge of water: Water Resources Research, v. 3, no.1, p. 263-269.

Duffield, G.M., and Rumbaugh, J.O., III, 1991, AQTESOLV ${ }^{\mathrm{TM}}$ Aquifer test solver documentation: Geraghty and Miller, Inc., vers. 1.1, $135 \mathrm{p}$.

Ferris, J.G., Knowles, D.B., Brown, R.H., and Stallman, R.W., 1962, Theory of aquifer tests: U.S. Geological Survey Water-Supply Paper 1536-E, p. 69-171.

Froelich, A.J., and Gottfried, David, 1985, Early Jurassic diabase sheets of the eastern United States-a preliminary overview: U.S. Geological Survey Circular 946, p. 79-86.

Hotz, P.E., 1952, Form of diabase sheets in southeastern Pennsylvania: American Journal of Science, v. 250, p. 375-388.

Lyttle, P.T., and Epstein, J.B., 1987, Geologic map of the Newark $1^{\circ}$ x $2^{\circ}$ quadrangle, New Jersey, Pennsylvania, and New York: U.S. Geological Survey Miscellaneous Investigations Series I-1715, 2 plates, scale 1:250,000.

Papadopulos, I.S., and Cooper, H.H., Jr., 1967, Drawdown in a well of large diameter: Water Resources Research, v. 3, no.1, p. 241-244.

Reed, J.E., 1980, Type curves for selected problems of flow to wells in confined aquifers: U.S. Geological Survey Techniques of Water-Resource Investigations, Book 3, Chap. B1, 106 p.

Sloto, R.A., and Schreffler, C.L., 1994, Hydrogeology and ground-water quality of northern Bucks County, Pennsylvania: U.S. Geological Survey Water-Resources Investigations Report 94-4109, 85 p.

Theis, C.V., 1935, The relation between the lowering of the piezometric surface and the rate and duration of discharge of a well using ground-water storage: Am. Geophy. Union Trans., v. 16, p. 519-524.

Willard, D.B., Freedman, Jacob, McLaughlin, D.B., Peltier, L.C., Gault H.R., 1959, Geology and mineral resources of Bucks County, Pennsylvania: Pennsylvania Geological Survey, 4th ser., Bulletin C9, $243 \mathrm{p}$. 
APPENDIX 1. GRAPHS OF DRAWDOWN PLOTS FOR SLUG TESTS 


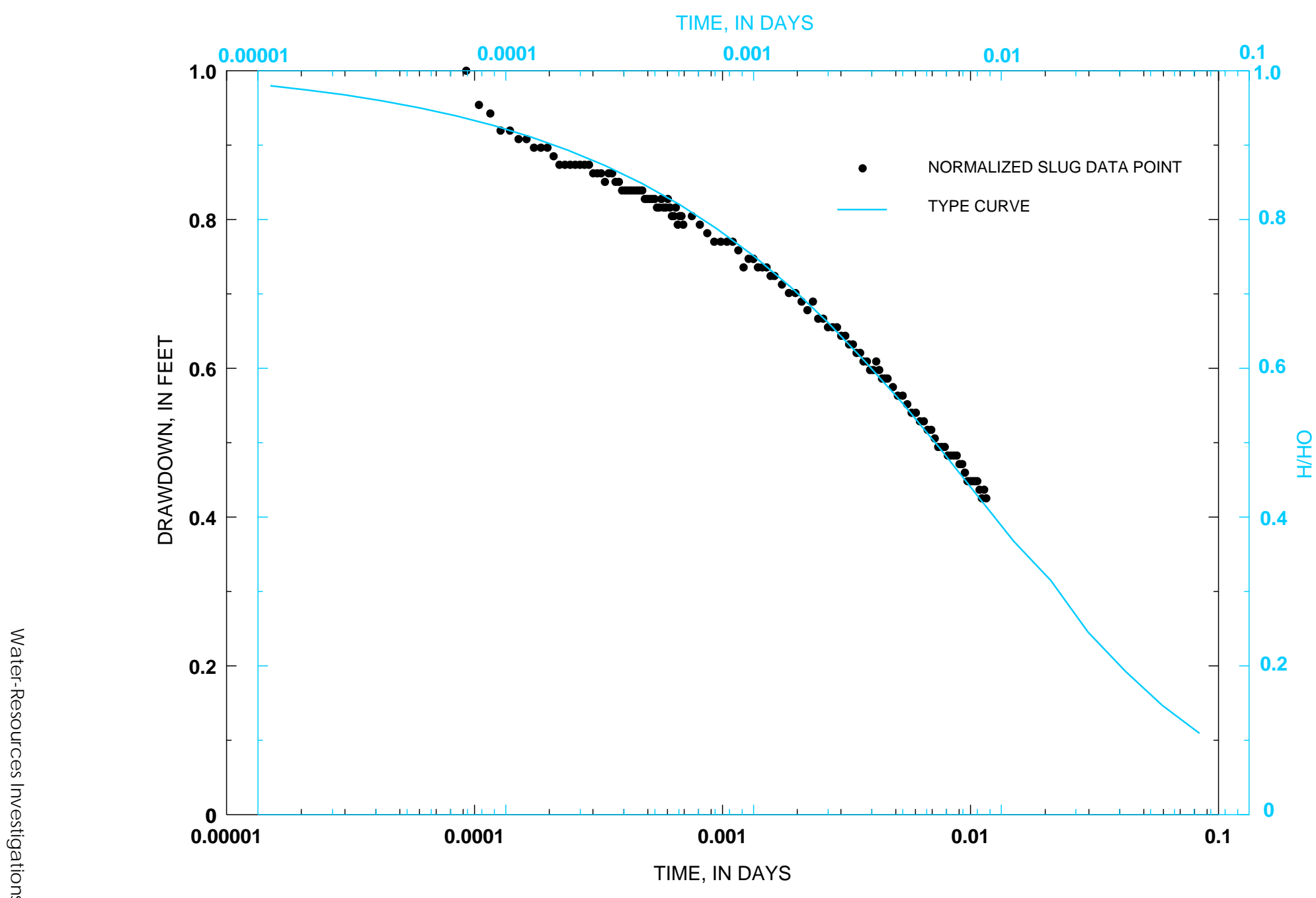

Figure 1. Drawdown versus logarithm of time and corresponding type curve for slug test of borehole BK-2631, Boarhead Farms site, Bridgeton Township, Bucks County, Pa. 


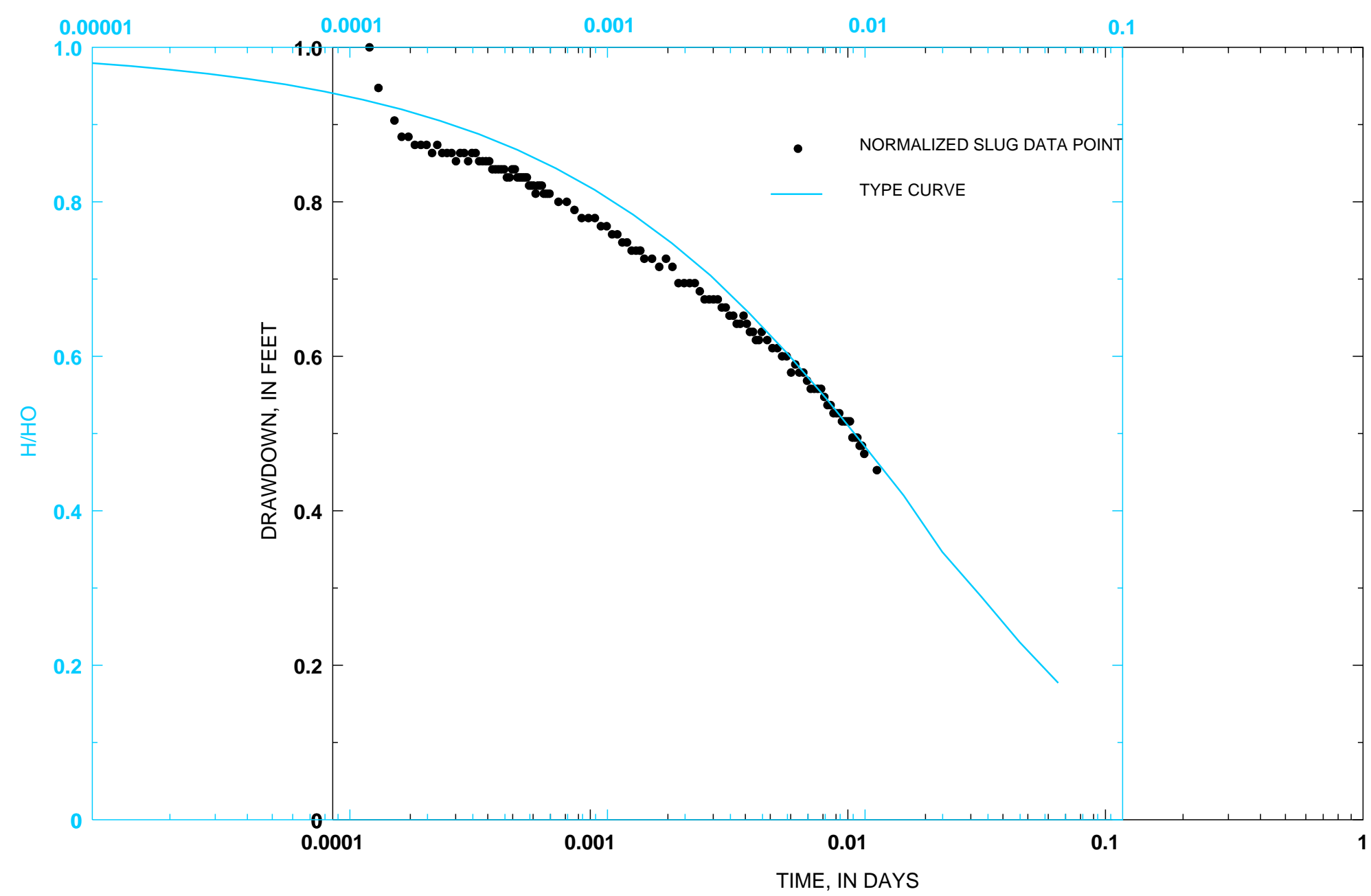

Figure 2. Drawdown versus logarithm of time and corresponding type curve for slug test of borehole BK-2632, Boarhead Farms site, Bridgeton Township, Bucks County, Pa. 


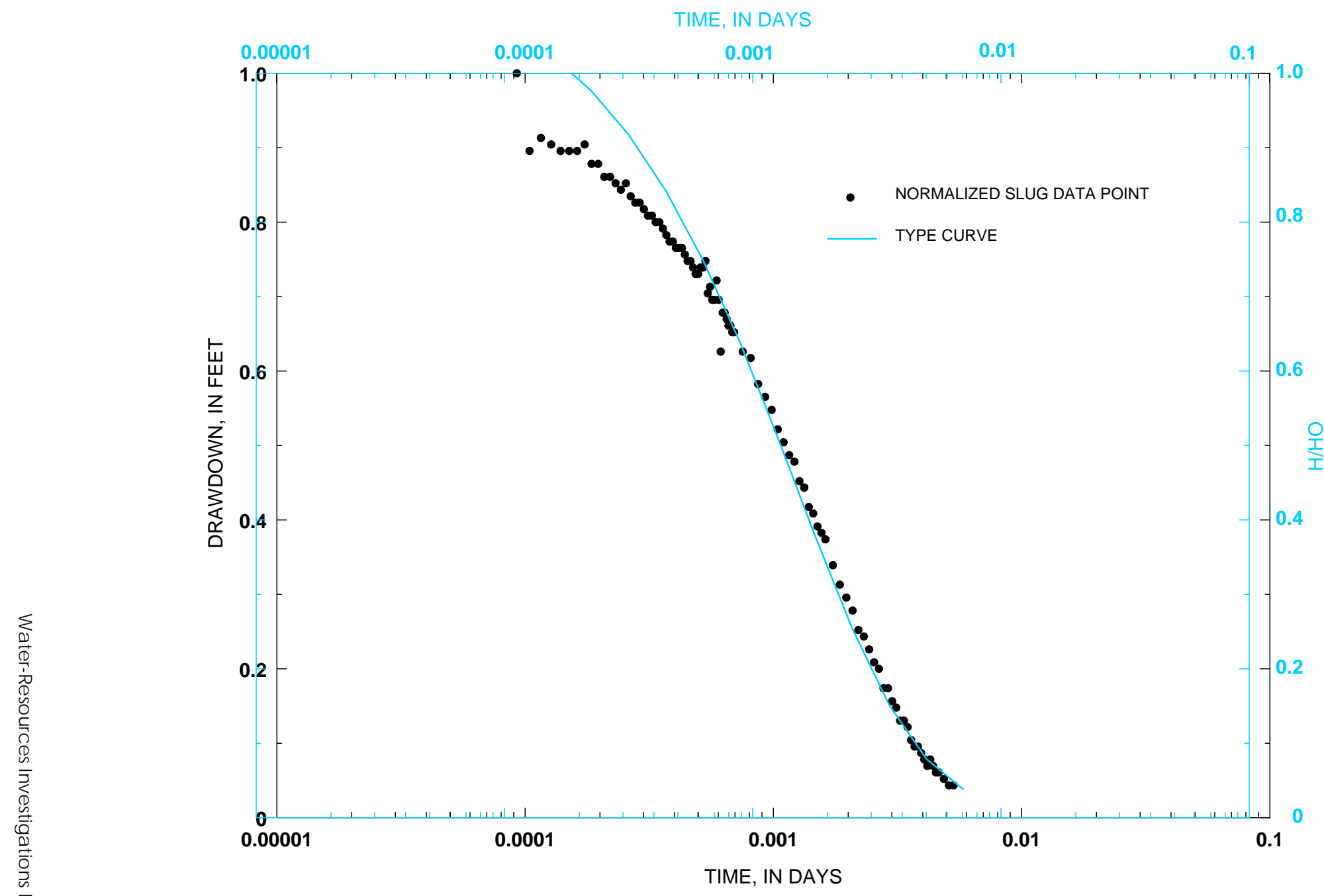

Figure 3. Drawdown versus logarithm of time and corresponding type curve for slug test of borehole BK-2636, Boarhead Farms site, Bridgeton Township, Bucks County, Pa. 
TIME, IN DAYS

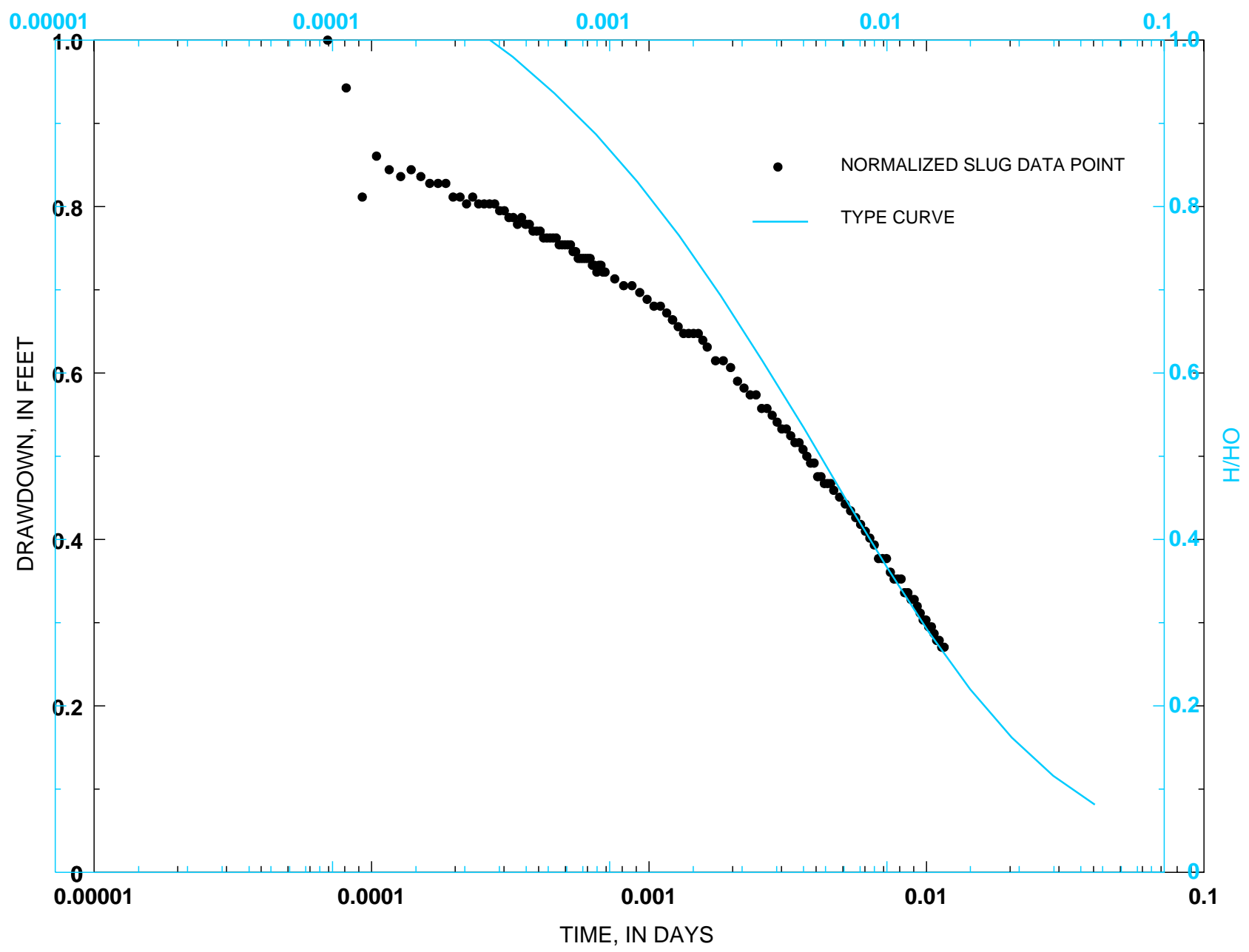

Figure 4. Drawdown versus logarithm of time and corresponding type curve for slug test of borehole BK-2639, Boarhead Farms site, Bridgeton Township, Bucks County, $\mathrm{Pa}$. 


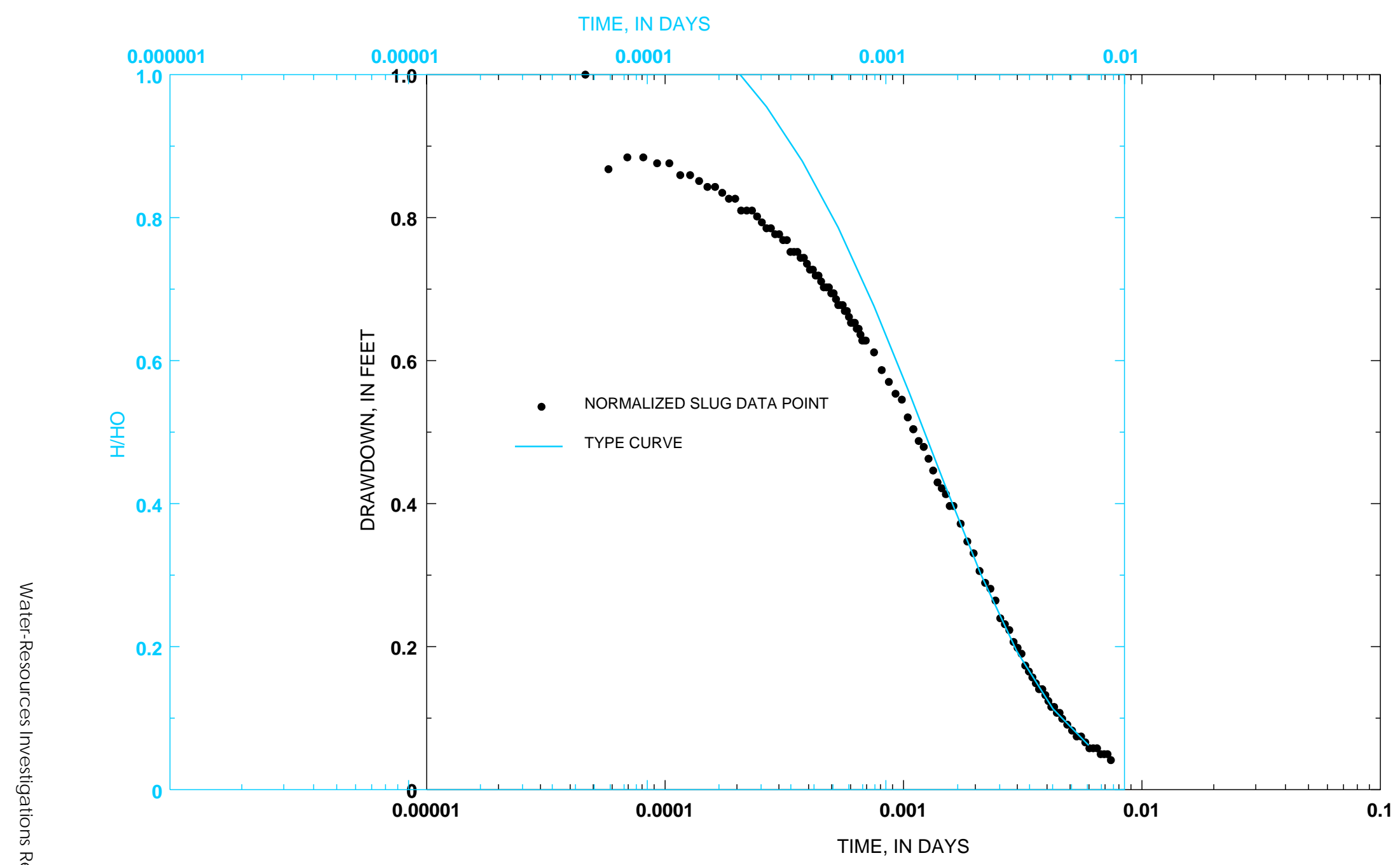

Figure 5. Drawdown versus logarithm of time and corresponding type curve for slug test of borehole BK-2640, Boarhead Farms site, Bridgeton Township, Bucks County, Pa. 
TIME, IN DAYS

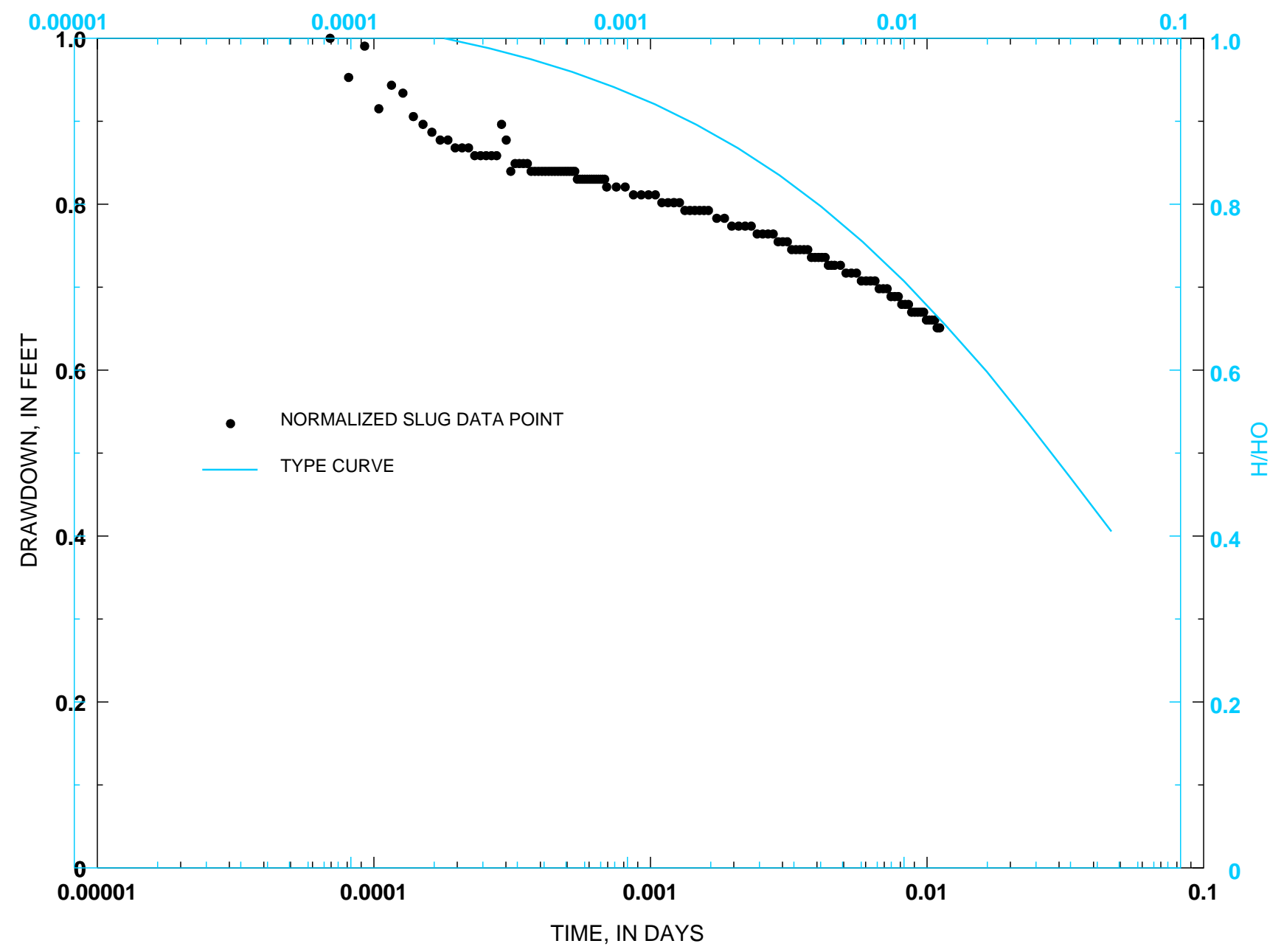

Figure 6. Drawdown versus logarithm of time and corresponding type curve for slug test of borehole BK-2641, Boarhead Farms site, Bridgeton Township, Bucks County, Pa. 


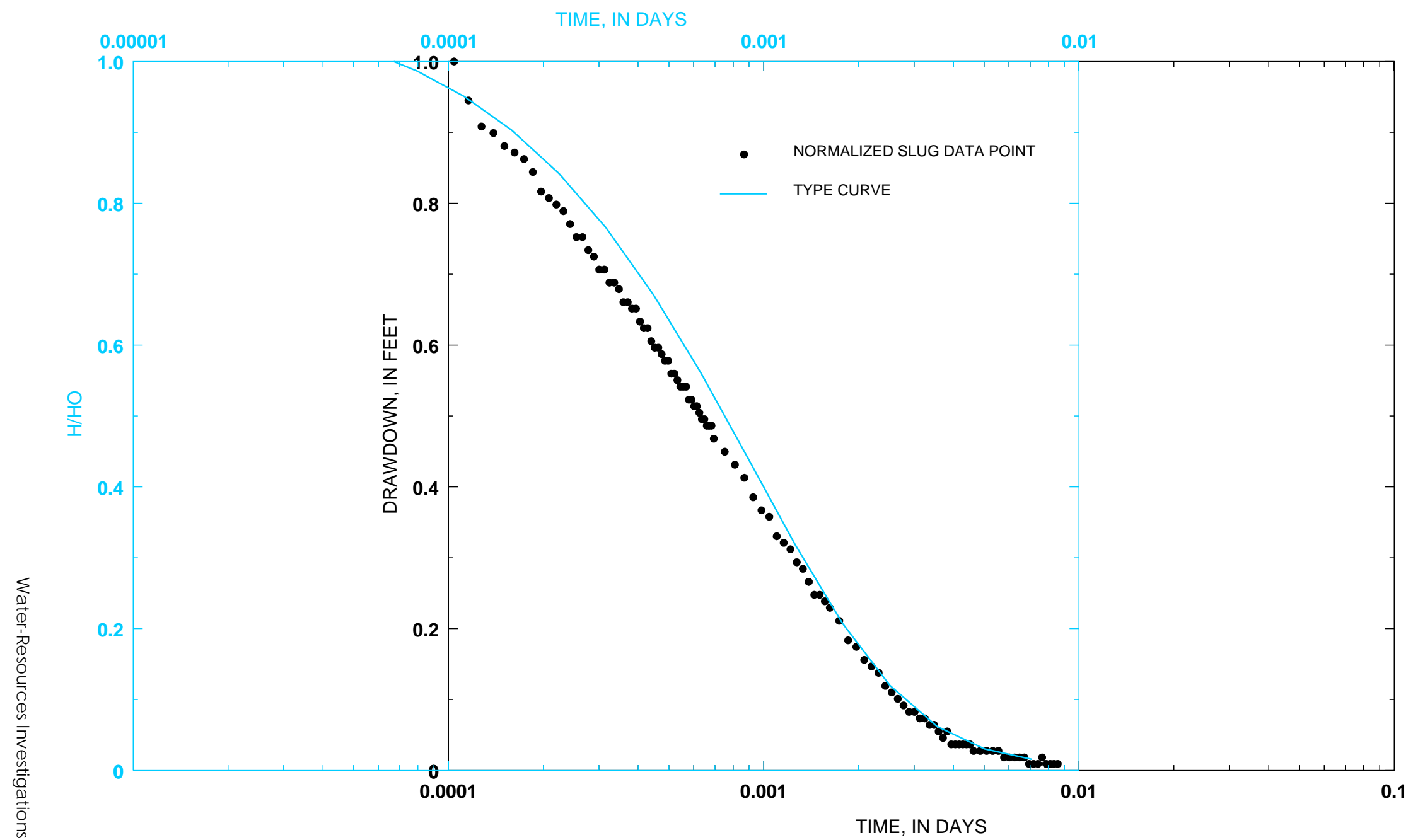

Figure 7. Drawdown versus logarithm of time and corresponding type curve for slug test of borehole BK-2642, Boarhead Farms site, Bridgeton Township, Bucks County, Pa. 
TIME, IN DAYS

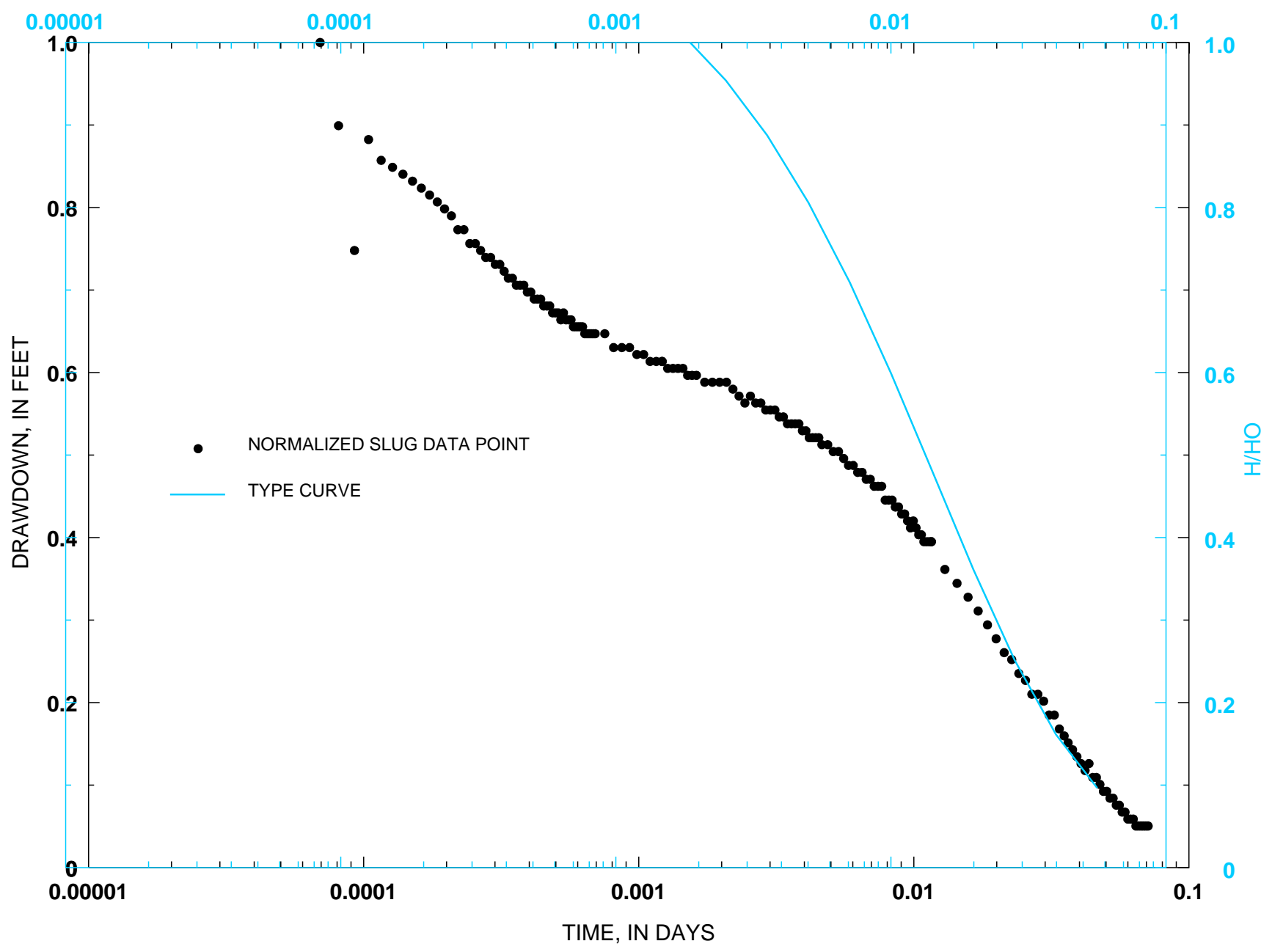

Figure 8. Drawdown versus logarithm of time and corresponding type curve for slug test of borehole BK-2643, Boarhead Farms site, Bridgeton Township, Bucks County, Pa. 


\section{APPENDIX 2. GRAPHS OF DRAWDOWN PLOTS FOR ISOLATED-ZONE}

CONSTANT-DISCHARGE TESTS 
APPENDIX 2. GRAPHS OF DRAWDOWN PLOTS FOR ISOLATED-ZONE CONSTANT-DISCHARGE TESTS

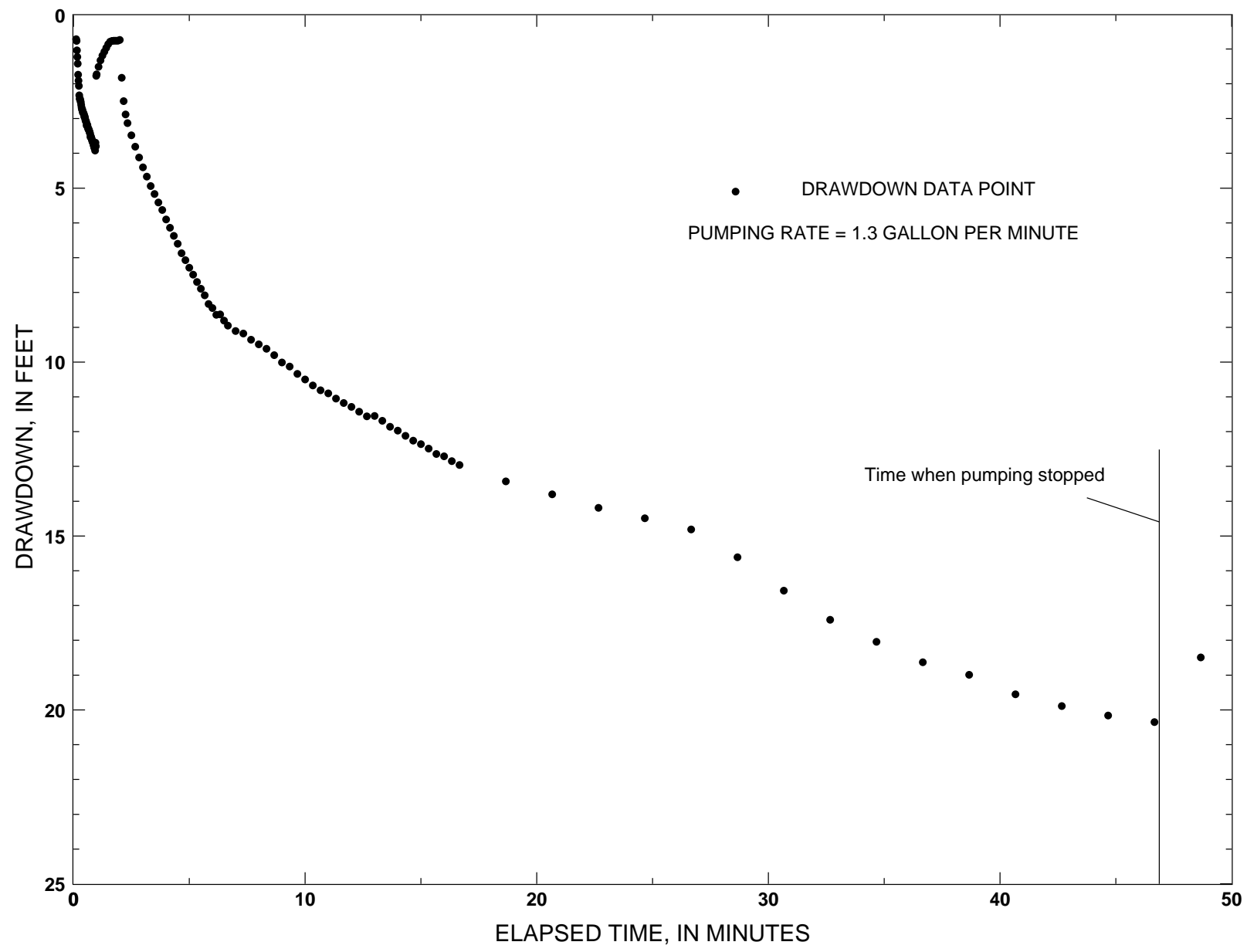

Figure 1. Drawdown versus time in the upper zone of borehole BK-2632 for the isolated-zone constant-discharge test, September 27, 1994, Boarhead Farms site, Bridgeton Township, Bucks County, Pa. 
APPENDIX 2. GRAPHS OF DRAWDOWN PLOTS FOR ISOLATED-ZONE CONSTANT-DISCHARGE TESTS

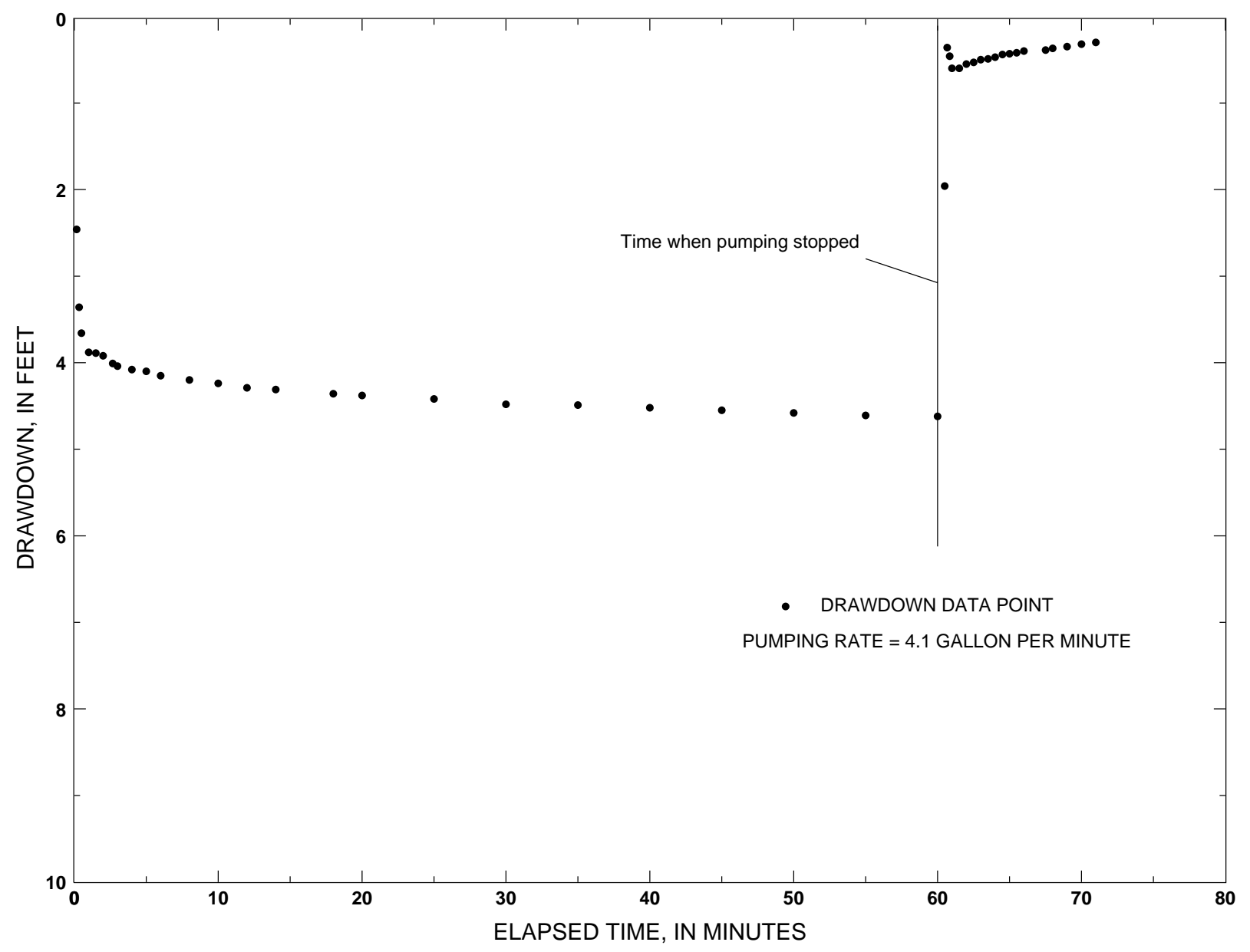

Figure 2. Drawdown versus time in the upper zone of borehole BK-2636 for the isolated-zone constant-discharge test, September 22, 1994, Boarhead Farms site, Bridgeton Township, Bucks County, Pa. 
APPENDIX 2. GRAPHS OF DRAWDOWN PLOTS FOR ISOLATED-ZONE CONSTANT-DISCHARGE TESTS

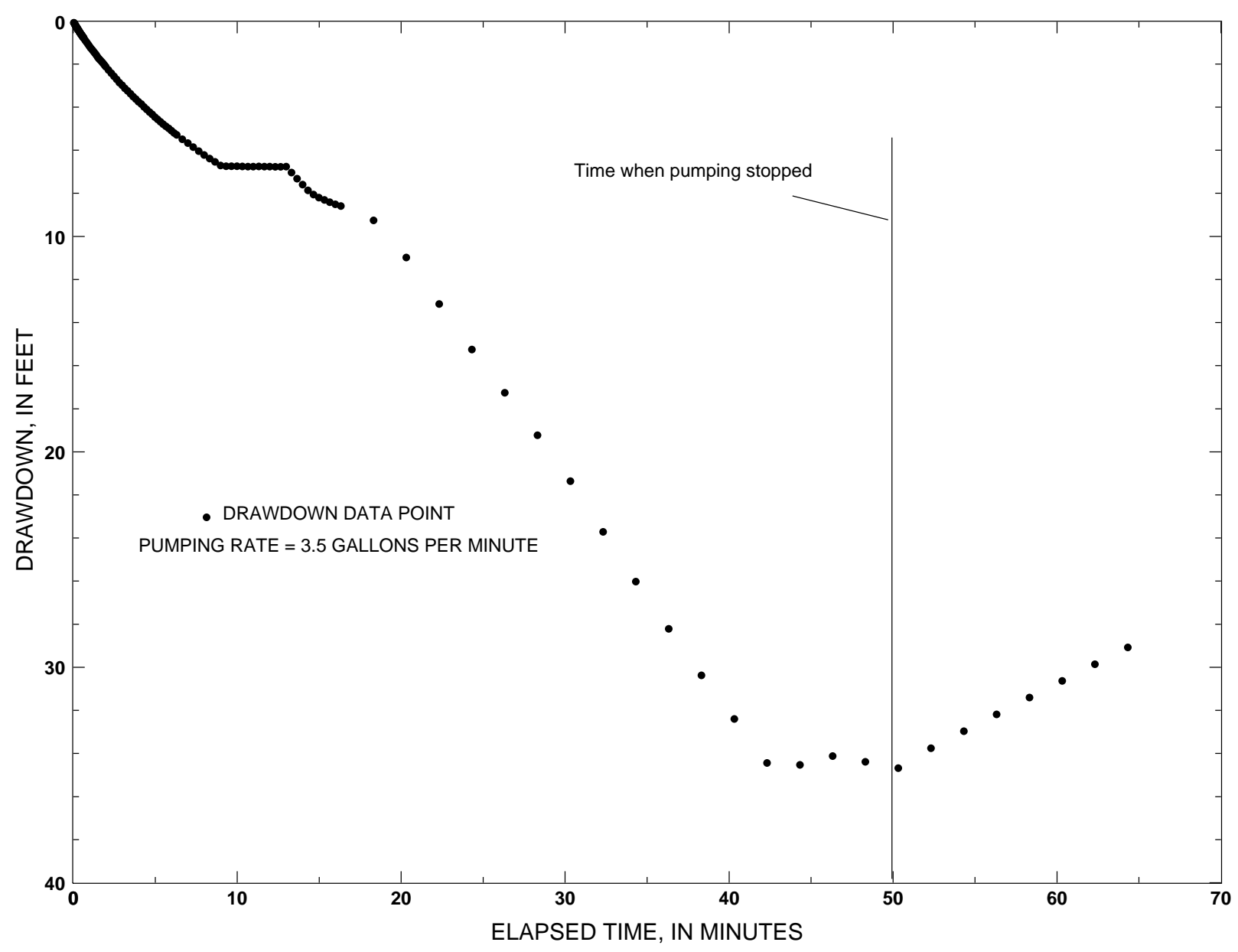

Figure 3. Drawdown versus time in the upper zone of borehole BK-2639 for the isolated-zone constant-discharge test, September 29, 1994, Boarhead Farms site, Bridgeton Township, Bucks County, Pa. 
APPENDIX 2. GRAPHS OF DRAWDOWN PLOTS FOR ISOLATED-ZONE CONSTANT-DISCHARGE TESTS

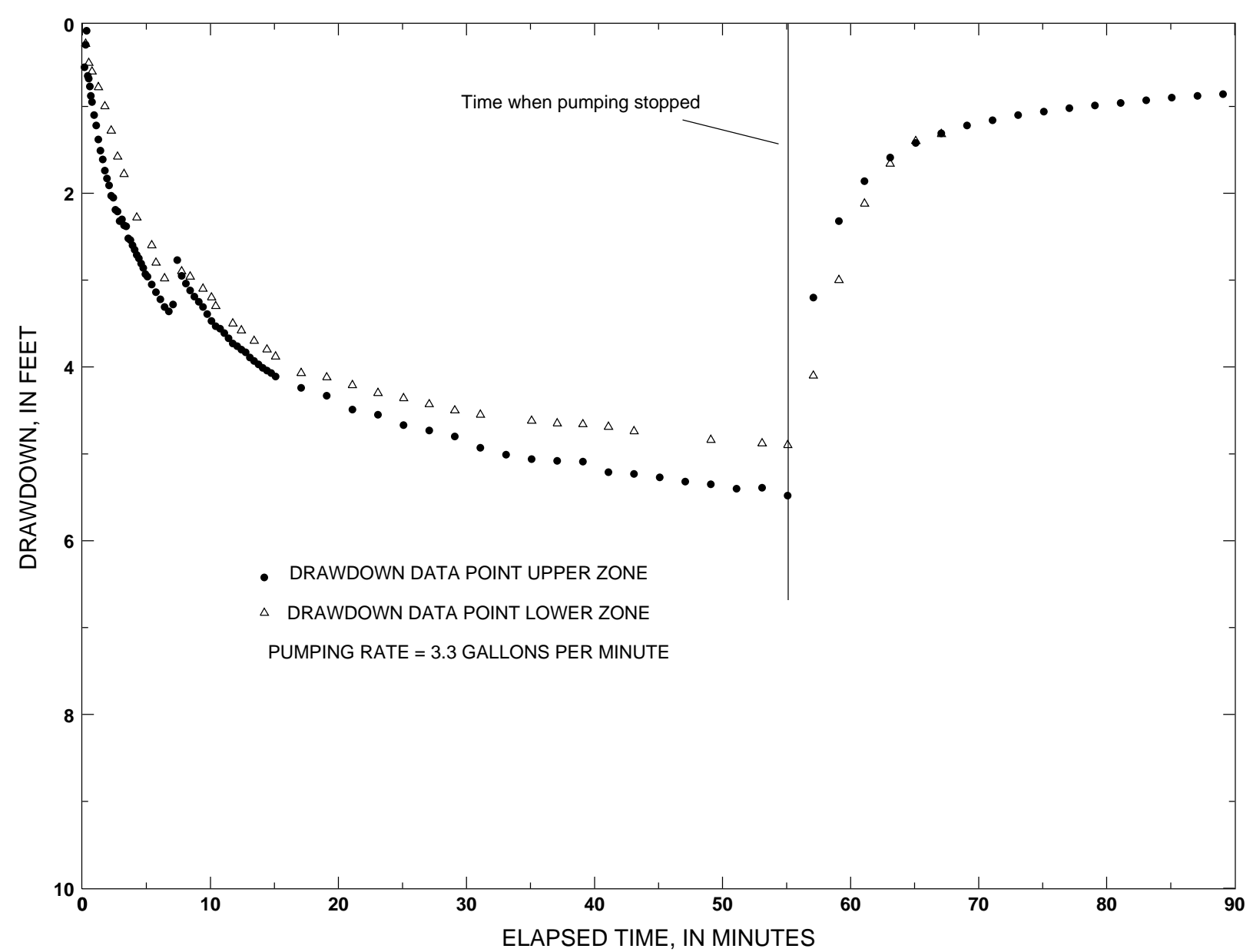

Figure 4. Drawdown versus time in the upper and lower zones of borehole BK-2640 for the isolated-zone constant-discharge test, September 27, 1994, Boarhead Farms site, Bridgeton Township, Bucks County, Pa. 
APPENDIX 2. GRAPHS OF DRAWDOWN PLOTS FOR ISOLATED-ZONE CONSTANT-DISCHARGE TESTS

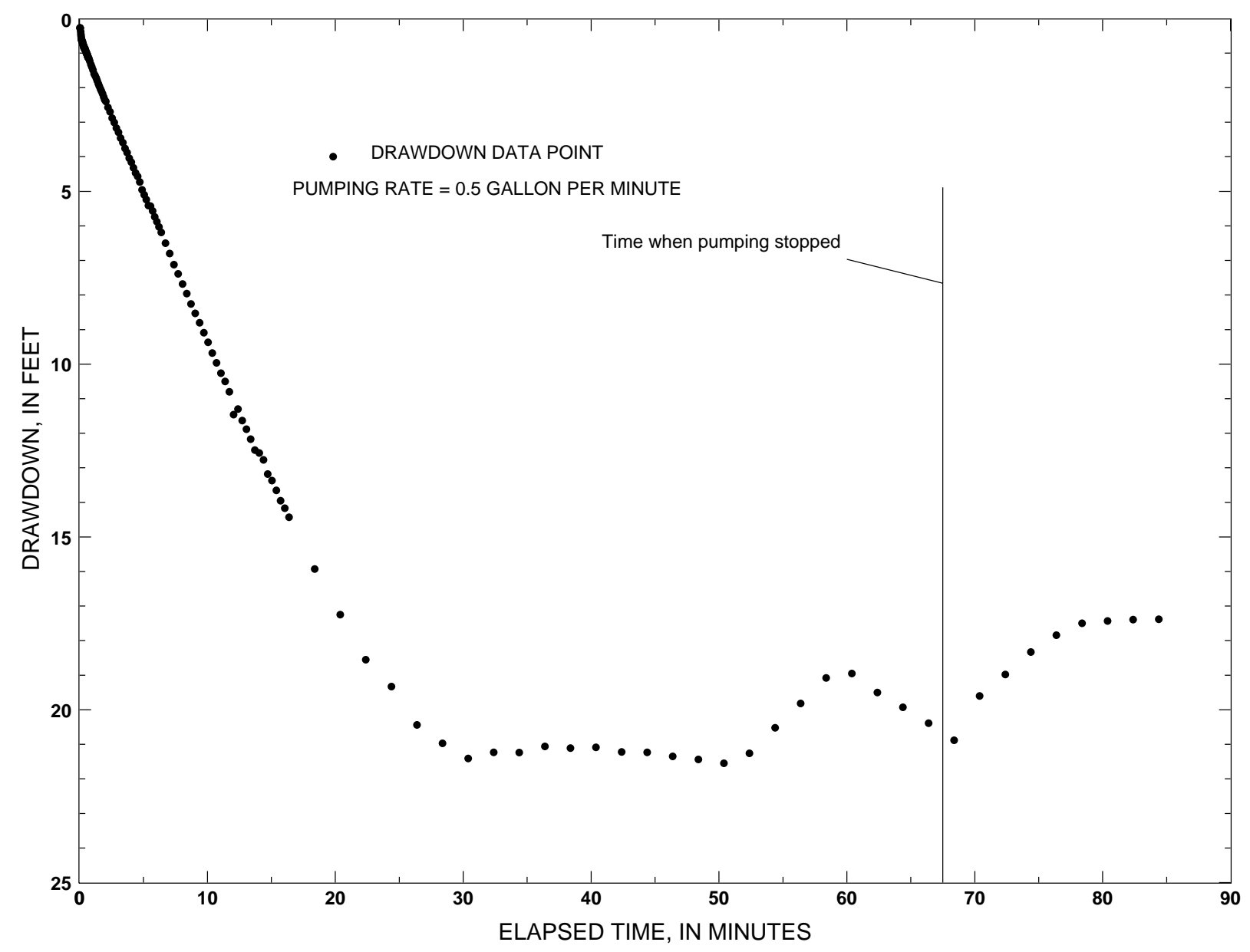

Figure 5. Drawdown versus time in the upper zone of borehole BK-2641 for the isolated-zone constant-discharge test, September 28, 1994, Boarhead Farms site, Bridgeton Township, Bucks County, Pa. 
APPENDIX 2. GRAPHS OF DRAWDOWN PLOTS FOR ISOLATED-ZONE CONSTANT-DISCHARGE TESTS

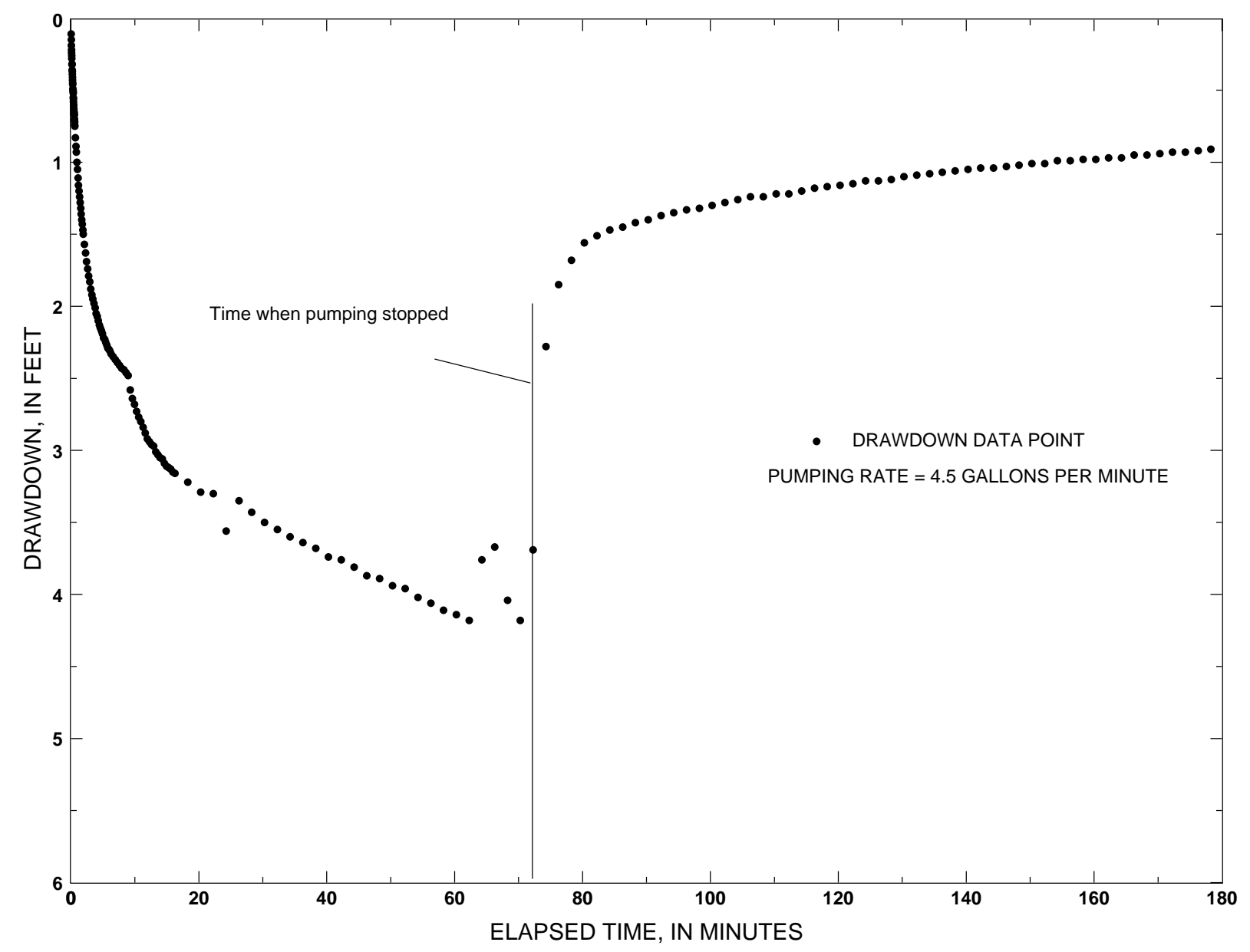

Figure 6. Drawdown versus time in the upper zone of borehole BK-2642 for the isolated-zone constant-discharge test, October 4, 1994, Boarhead Farms site, Bridgeton Township, Bucks County, Pa. 
APPENDIX 2. GRAPHS OF DRAWDOWN PLOTS FOR ISOLATED-ZONE CONSTANT-DISCHARGE TESTS

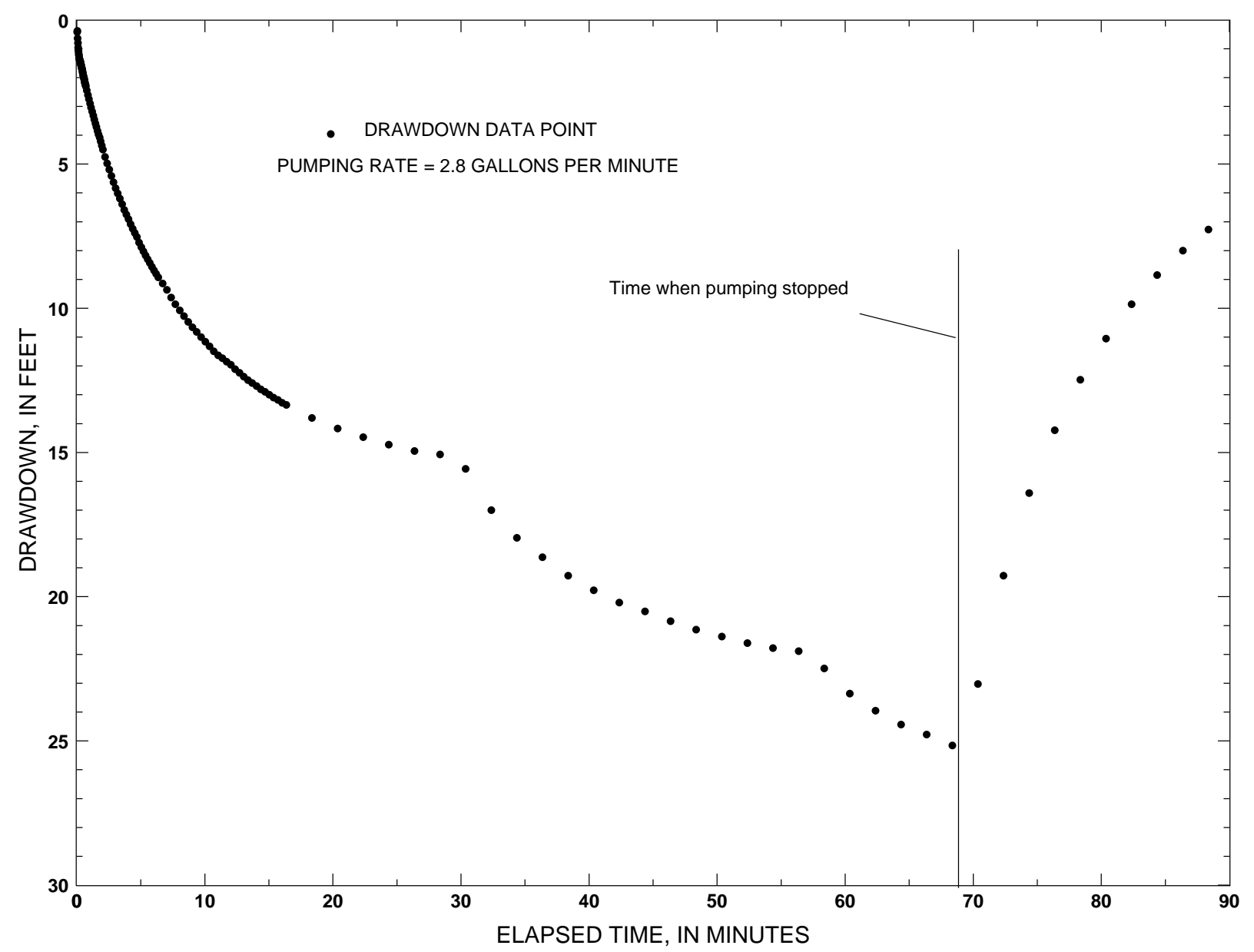

Figure 7. Drawdown versus time in the lower zone of borehole BK-2643 for the isolated-zone constantdischarge test, October 5, 1994, Boarhead Farms site, Bridgeton Township, Bucks County, Pa. 
APPENDIX 3. GRAPHS OF DRAWDOWN PLOTS FOR OPEN-HOLE CONSTANT-DISCHARGE TESTS 
$1 / \mu$

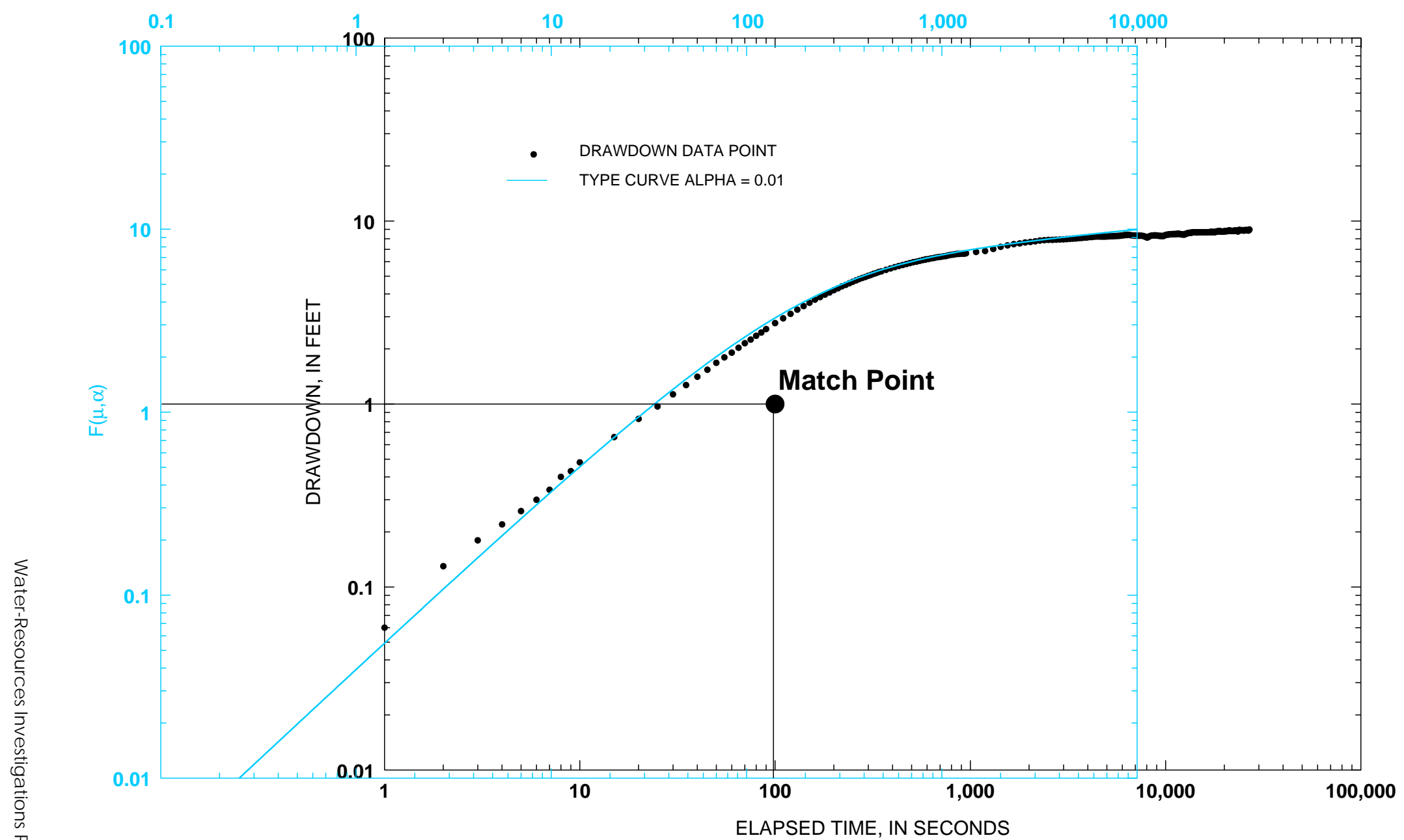

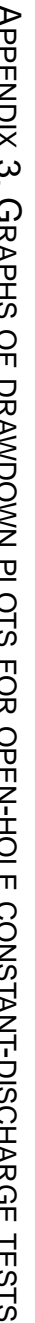

Figure 1. Logarithm of drawdown versus logarithm of time and corresponding type curve with match point for open-hole constant-discharge test of borehole BK-2636 on October 26, 1994, Boarhead Farms site, Bridgeton Township, Bucks County, Pa. 


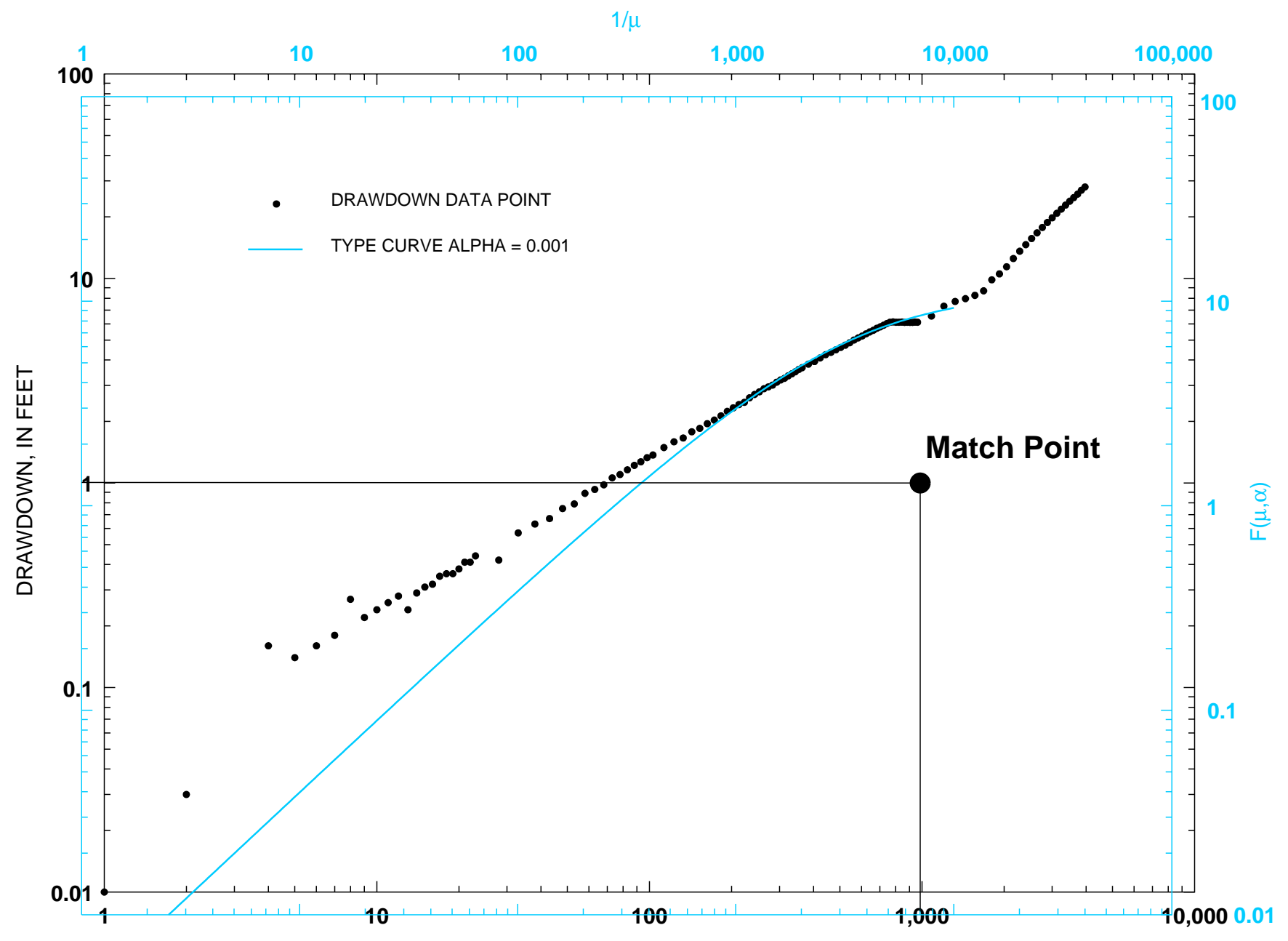

Figure 2. Logarithm of drawdown versus logarithm of time and corresponding type curve with match point for open-hole constantdischarge test of borehole BK-2639 on October 19, 1994, Boarhead Farms site, Bridgeton Township, Bucks County, Pa. 


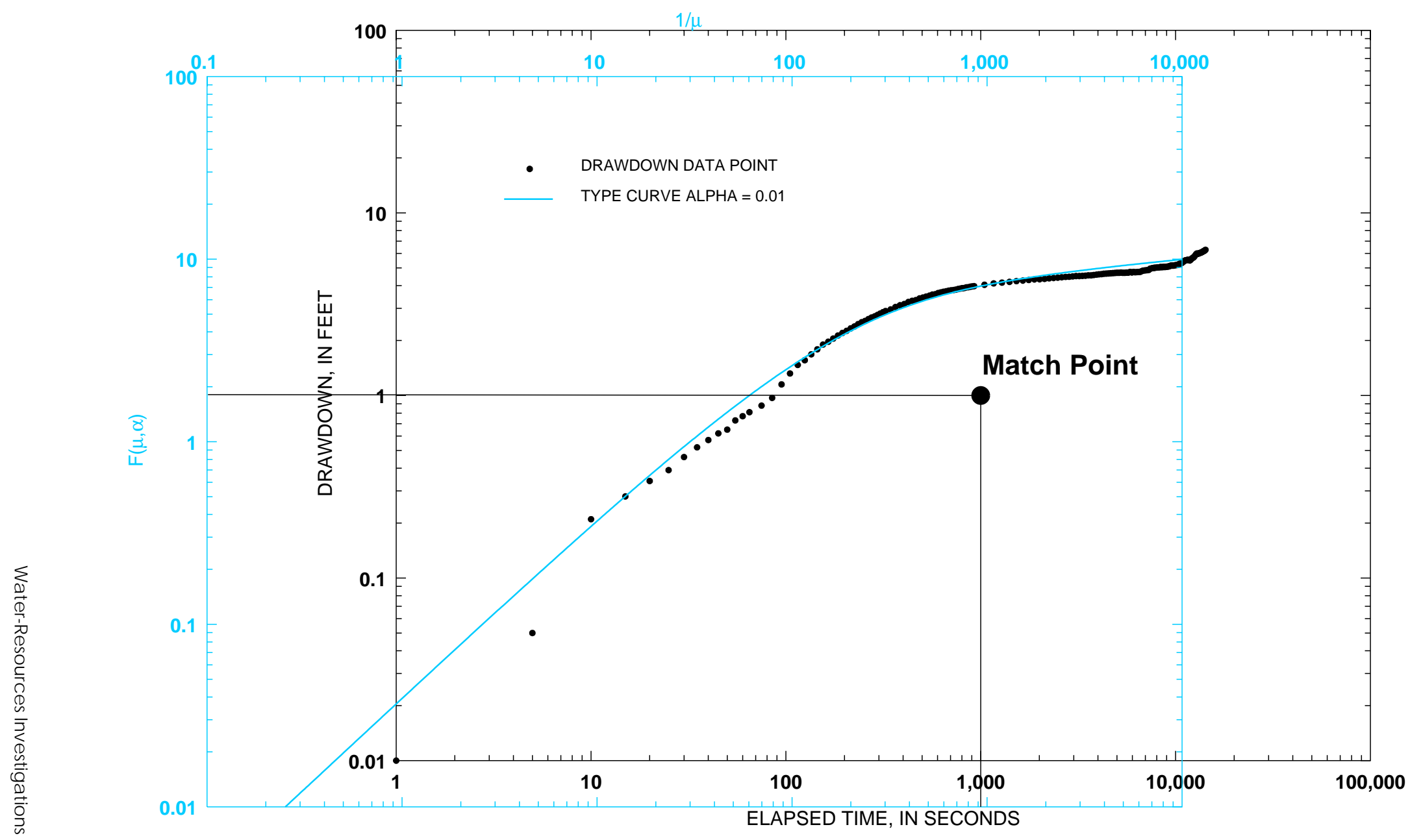

Figure 3. Logarithm of drawdown versus logarithm of time and corresponding type curve with match point for open-hole constantdischarge test of borehole BK-2640 on October 17, 1994, Boarhead Farms site, Bridgeton Township, Bucks County, Pa. 


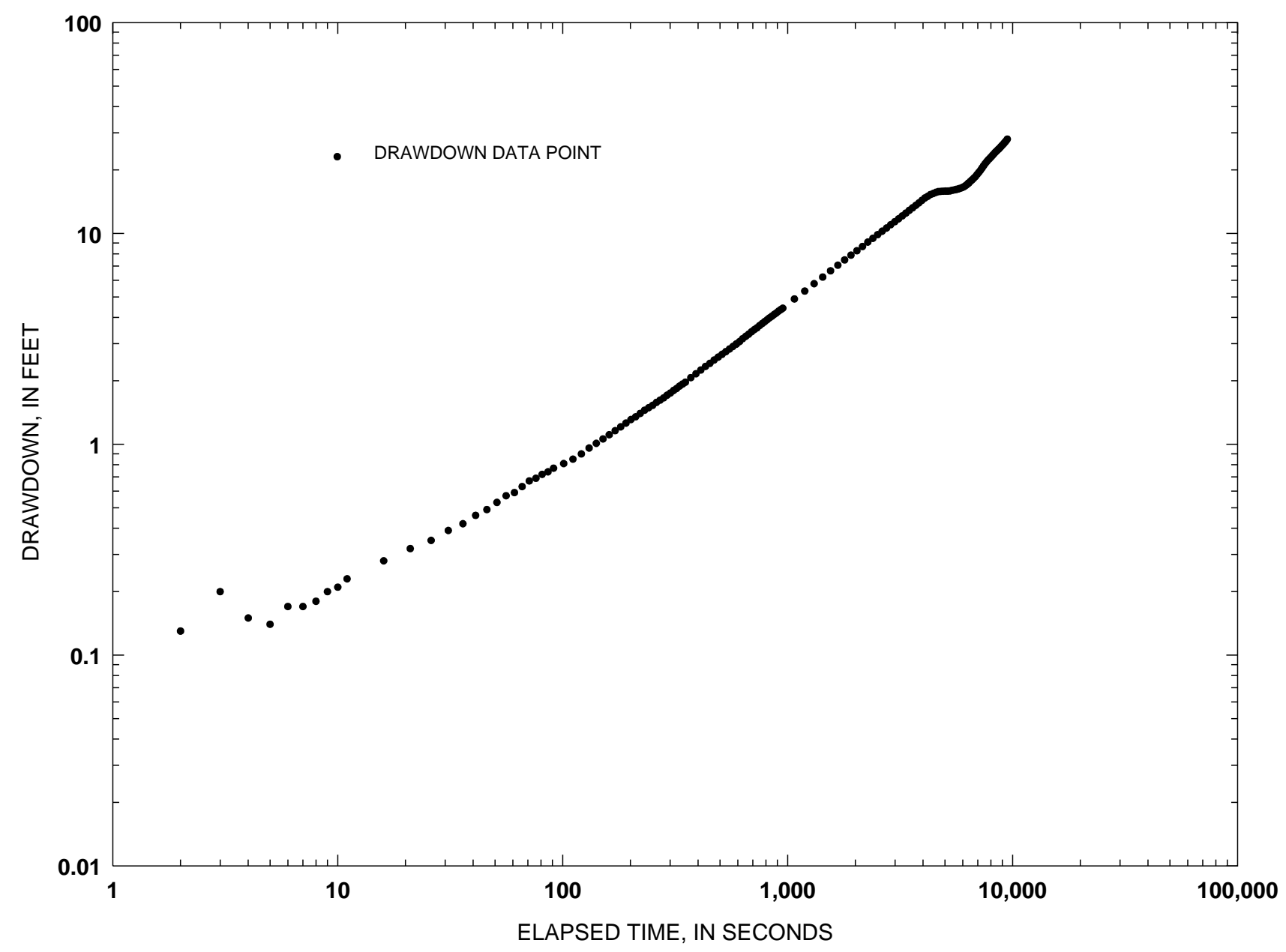

Figure 4. Logarithm of drawdown versus logarithm of time for open-hole constant-discharge test of borehole BK-2641 on October 28, 1994, Boarhead Farms site, Bridgeton Township, Bucks County, Pa. 


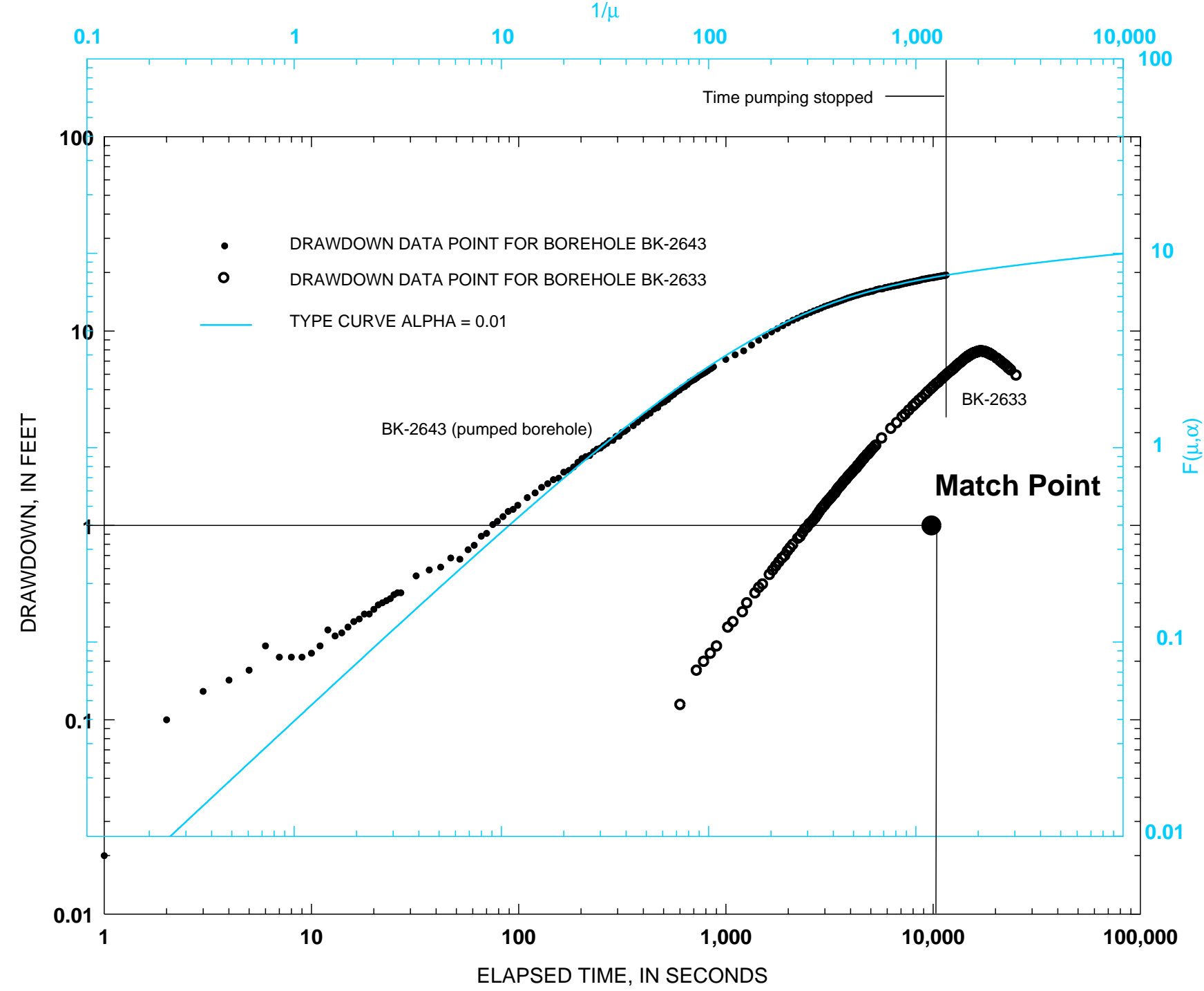

Figure 5. Logarithm of drawdown versus logarithm of time and corresponding type curve with match point for open-hole constantdischarge test of borehole BK-2643 on October 20, 1994, Boarhead Farms site, Bridgeton Township, Bucks County, Pa. 